\title{
Effect of well configurations on productivity index of gas well producing from shale
}

\author{
Emaadeldein Abdullaay \\ West Virginia University
}

Follow this and additional works at: https://researchrepository.wvu.edu/etd

\section{Recommended Citation}

Abdullaay, Emaadeldein, "Effect of well configurations on productivity index of gas well producing from shale" (2009). Graduate Theses, Dissertations, and Problem Reports. 4436.

https://researchrepository.wvu.edu/etd/4436

This Thesis is protected by copyright and/or related rights. It has been brought to you by the The Research Repository @ WVU with permission from the rights-holder(s). You are free to use this Thesis in any way that is permitted by the copyright and related rights legislation that applies to your use. For other uses you must obtain permission from the rights-holder(s) directly, unless additional rights are indicated by a Creative Commons license in the record and/ or on the work itself. This Thesis has been accepted for inclusion in WVU Graduate Theses, Dissertations, and Problem Reports collection by an authorized administrator of The Research Repository @ WVU. For more information, please contact researchrepository@mail.wvu.edu. 


\title{
Effect of Well Configurations on Productivity Index of Gas Well Producing From Shale
}

\author{
Emaadeldein Abdullaay \\ A Thesis Submitted to the College of \\ Engineering and Mineral Resources \\ At West Virginia University \\ In partial fulfillment of the requirements \\ For the degree of \\ Master of Science \\ in \\ Petroleum and Natural Gas Engineering \\ Dr. H. Ilkin Bilgesu, Ph.D., Chairperson \\ Prof. Samuel Ameri, M.S. \\ Dr. K. Aminian, Ph.D. \\ Department of Petroleum and Natural Gas Engineering \\ Morgantown, West Virginia \\ 2009
}

Keywords: Multilateral wells, Productivity Index, Hydraulic Fracturing, Shale Gas

Copyright 2009 Emaadeldein Abdullaay 


\section{ABSTRACT \\ Effect of Well Configurations on Productivity Index of Gas Well Producing From Shale}

\section{Emaadeldein Abdullaay}

This study investigates the effect of various well configurations (designs) and their impact on the productivity index of shale gas wells. Five different well configurations (Multilateral wells) are compared with a single horizontal well, which is taken as a base case $(\mathrm{BC})$. Both the base case and the different well configurations have the same drainage area, the initial gas in place and the total lateral lengths are equal. The data to calculate the productivity index and the modeling for the different well designs are obtained from reservoir simulation. The different flow regimes of each well configuration have been studied to look at their effect on the well productivity index and the effect of lateral interference. Intermediate linear flow to the hydraulic fractures is found to be the primary effect on the productivity index.

Dual - lateral well with $180^{\circ}$ between the two laterals is found to have better productivity index than the base case and the other four well configurations, these four well configurations have smaller angles between laterals, which resulted on shorter lateral spacing than the Dual - lateral well; thus lateral interference resulted in more pressure drop. 


\section{ACKNOWLEDGEMENT}

Firstly, I would like to thank God for giving me the health, mind and the support to be successful in my life.

I would like to thank my father Dr.Nasr Abdullaay and my lovely mother Arafa for their support and encouragement. And I want to express my thank to my wife for her patient through my research and for her support.

I want to express my gratitude to my advisor Dr. H. Ilkin Bilgesu for his advising through my research and for giving me the opportunity to work under his supervision.

I want to mention the support of the chairman of the Petroleum and Natural Gas Engineering Department at West Virginia University, Professor Samuel Ameri for his incomparable personality and his fatherhood to every student which makes our Department the best environment for study.

Many thanks to Dr.Khashayar Aminian for his attention and for being an excellent advisor for all the graduate students and for all the knowledge that he has transferred to us.

My special thanks to all faculty and staff at the Department of Petroleum and Natural Gas Engineering. I would like to send my special thanks to all my relatives back home in Sudan for their support and my thanks to all my friends and colleagues those I have met in West Virginia. 


\section{TABLE OF CONTENTS}

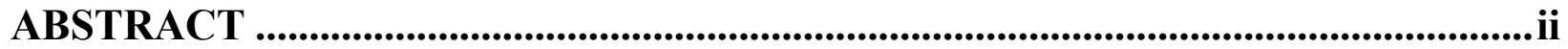

ACKNOWLEDGEMENT ........................................................................................................iii

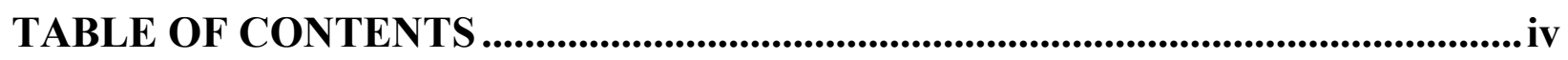

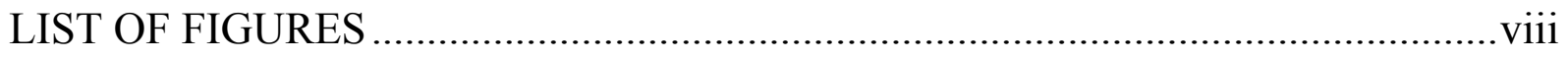

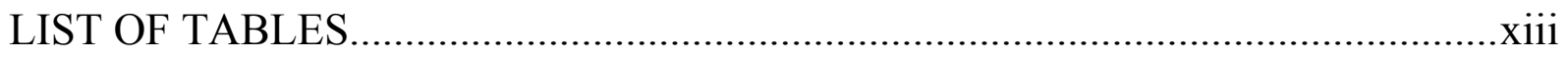

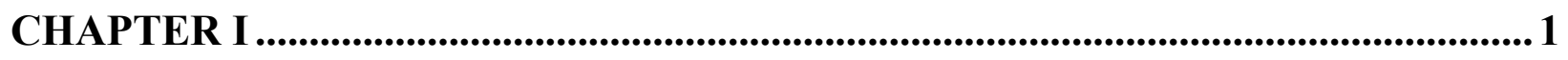

INTRODUCTION .................................................................................................................... 1

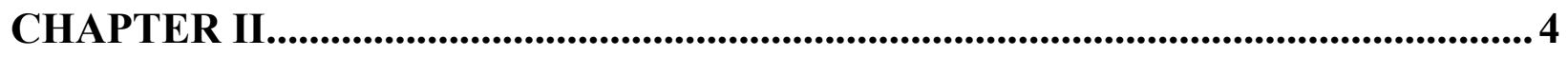

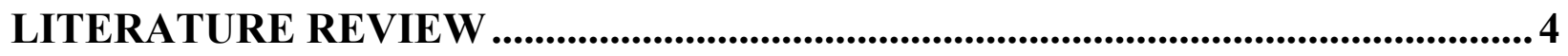

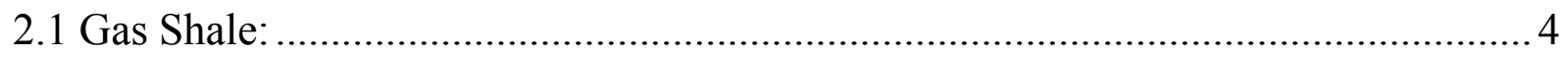

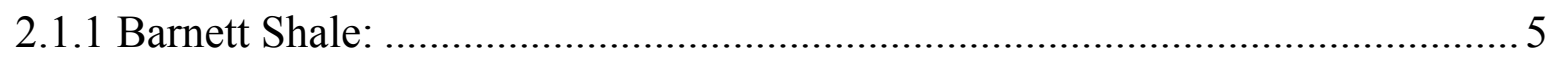

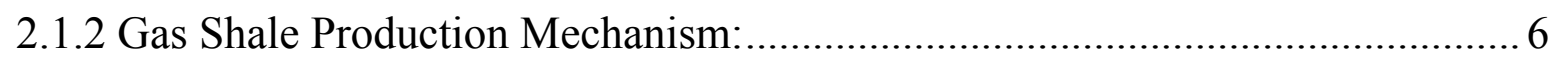

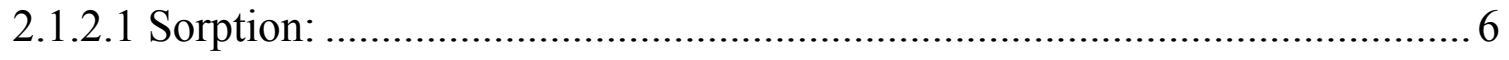

2.1.2.2 Compression of free gas in natural fractures and Matrix porosity:............. 7

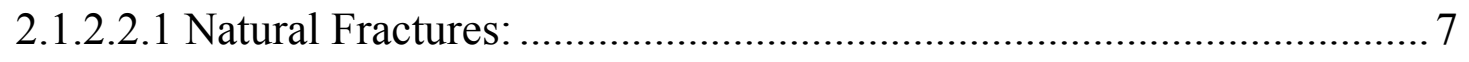

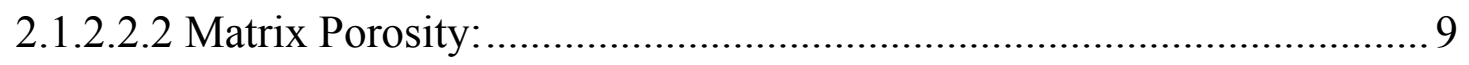




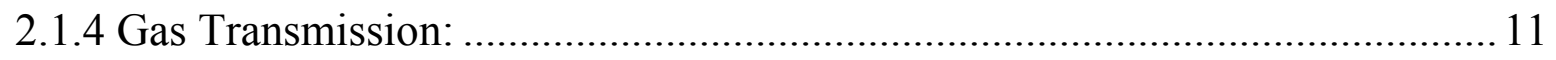

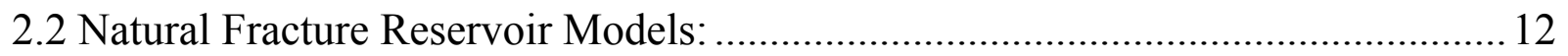

2.3 Productivity Index of Fractured Horizontal Gas Wells in Naturally Fractured Reservoirs (Dual - Porosity Reservoirs): ............................................................... 17

2.3.1 Medeiros F., Ozkan E. and Kazemi H. Model: .............................................. 17

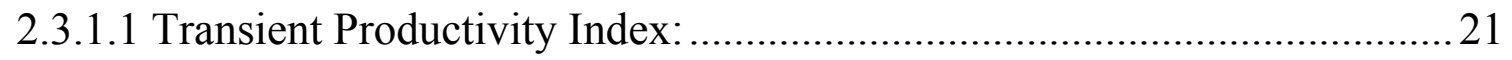

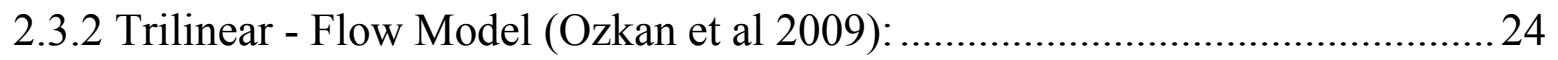

2.3.2.1 Productivity Index of the Multiply - Fractured Horizontal Gas Well: .....25

2.4 Flow Regimes of Horizontal wells in Naturally Fractured Reservoirs: ..................22

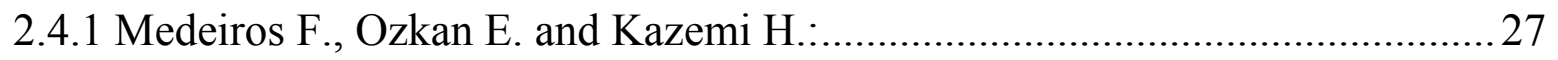

2.5 Application of Well Configurations (Multi - lateral wells):.................................... 32

2.5.1 Well Configurations in Gas Shale Formations:...............................................33

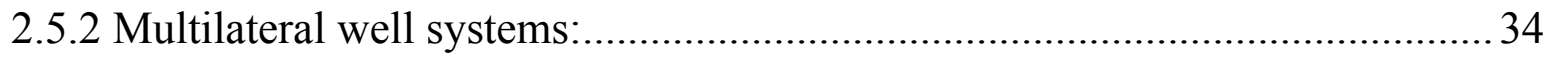

2.5.2.1 Economides, M.J., Retnanto, A. and Frick, T.P..................................... 35

2.5.2.2 Maricic, N., Mohaghegh, S.D. and Artun, E........................................... 37

2.5.2.3 Powell, A., Bustos, O., Kordziel, W., Olsen, T., Sobernheim, D. and

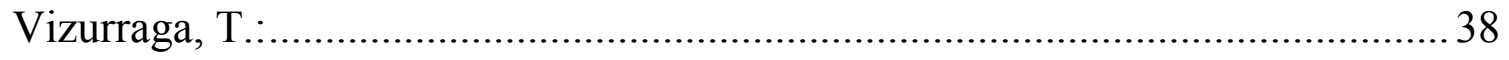

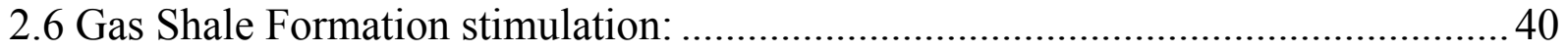

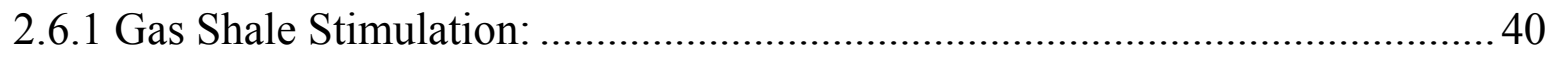

2.6.2 Multilateral well Stimulation:...................................................................... 41 


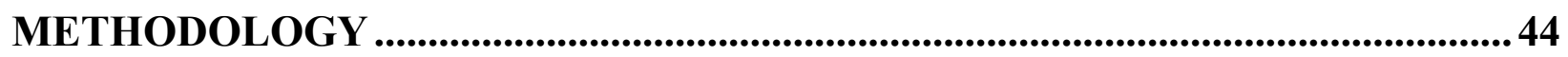

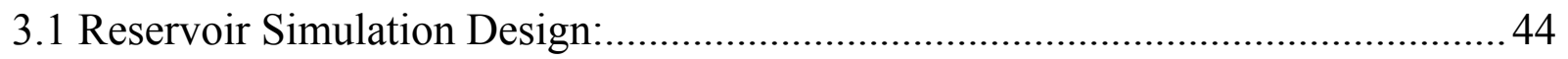

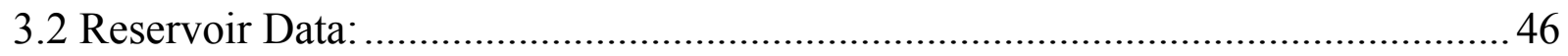

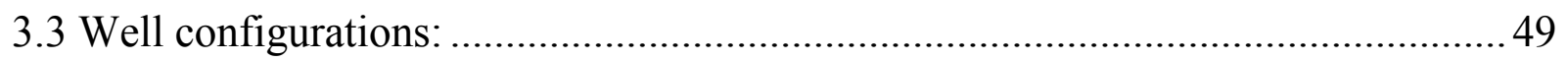

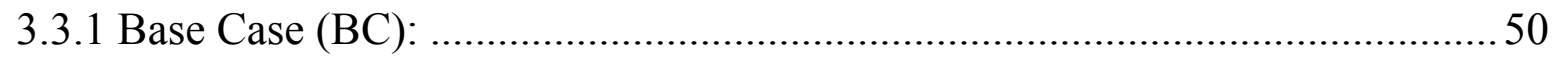

3.3.2 Two Parallel Horizontal Wells (TPHW):......................................................... 51

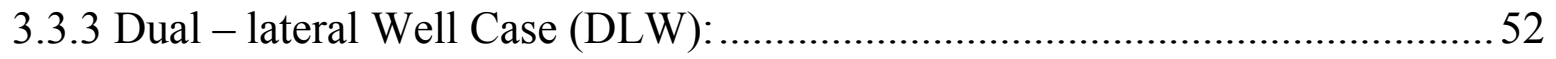

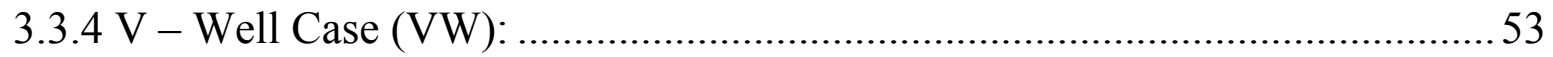

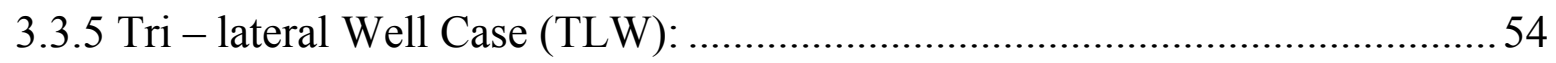

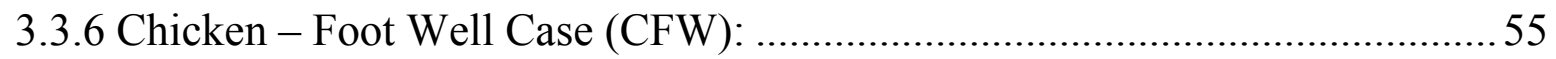

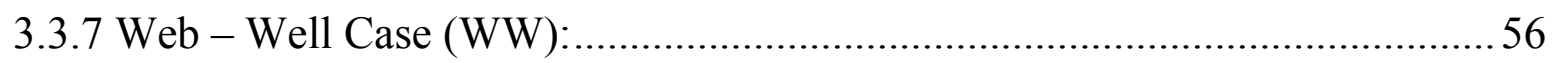

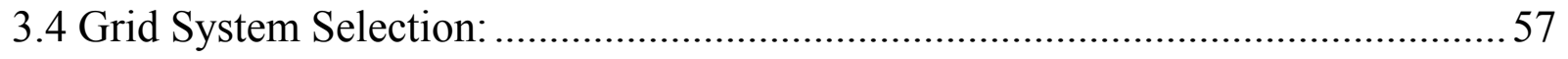

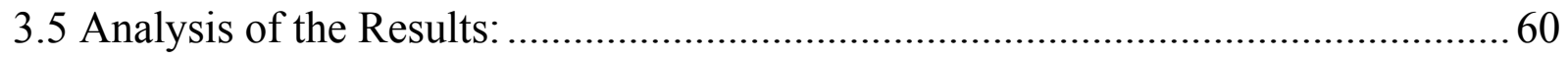

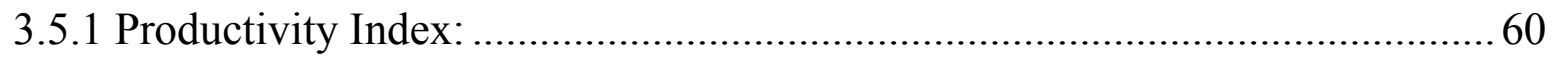

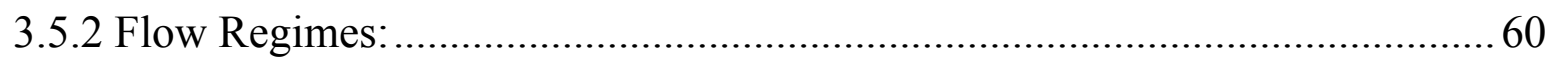

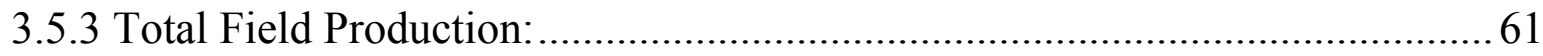


RESULTS and DISCUSSION

4.1 Base Case (BC) (Single horizontal well with 8 multi - stage hydraulic fractures): 62

4.2 Base Case (BC) versus Two parallel horizontal well (TPHW):.............................69

4.3 Base Case (BC) versus Dual - lateral well (DLW):............................................. 72

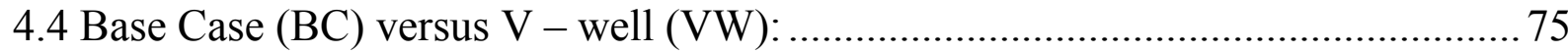

4.5 Base Case (BC) versus Tri - lateral well (TLW): ............................................... 78

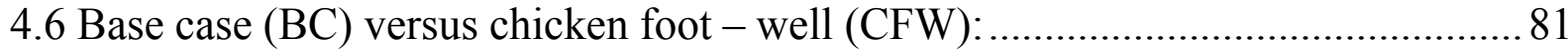

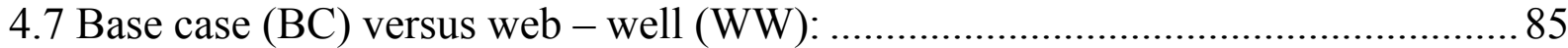

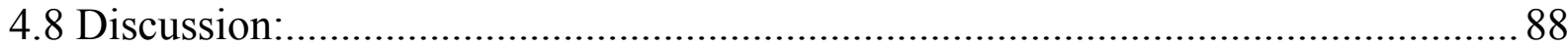

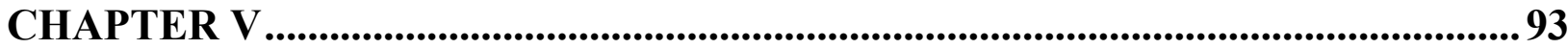

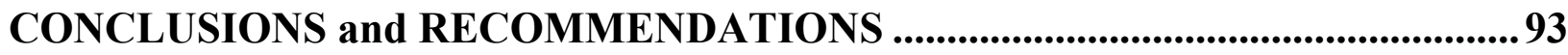

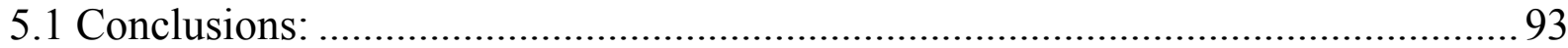

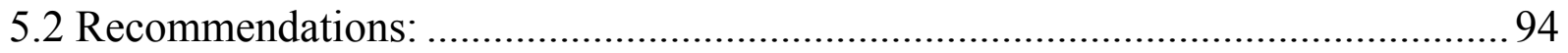

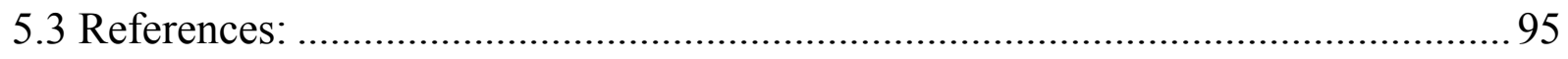




\section{LIST OF FIGURES}

Figure II-1 Major Shale Basins Play in United States of America (Waters, 2009).......... 5

Figure II-2 Natural fractures in the T.P.Sims core, Barnett Shale (Gale et al, 2007)....... 8

Figure II-3 Shale Reservoir Production Mechanism (Waters, 2009)................................ 9

Figure II-4 Adsorption isotherms for Barnett Shale core samples (Montgomery et al,

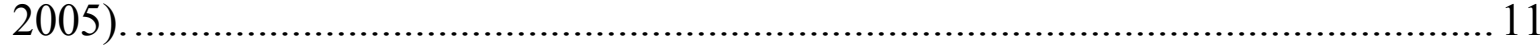

Figure II-5 Warren and Root, Dual - Porosity Model (Warren and Root, 1963)............ 12

Figure II-6 Type curve (Pressure and pressure derivative versus time) for dual - porosity reservoirs with different values for $\lambda$ (Well Test Interpretation, Schlumberger 2002).

Figure II-7 Type curve (Pressure and pressure derivative versus time) for dual - porosity reservoirs with different values for $\omega$ (Well Test Interpretation, Schlumberger 2002).

Figure II-8 Kazemi model \& Warren and Root model (Kazemi, 1969). 16

Figure II-9 Horizontal well with transverse fractures surrounded by dual - porosity regions (Medeiros et al, 2008).

Figure II-10 Schematic of the Trilinear - flow model used for the analytical solution of multiplies - fractured - horizontal well performance (Ozkan et al, 2009). 25

Figure II-11 Pseudopressure and derivative responses for a horizontal well in a homogeneous, tight formation (Medeiros et al, 2008).

Figure II-12 Pseudopressure and derivative responses for a horizontal well surrounded by a naturally fractured zone (Medeiros et al, 2008).

Figure II-13 Pseudopressure and derivative responses for a horizontal well with two transverse hydraulic fractures (Medeiros et al, 2008). 31

Figure II-14 Pseudopressure and derivative responses for a horizontal well with four transverse hydraulic fractures (Medeiros et al, 2008). 31

Figure II-15 Multilateral well designs (Economides et al, 1996). 35 
Figure II-16 Multilateral well designs (Economides et al, 1996)................................... 36

Figure II-17 Multilateral well designs (Maricic et al, 2005) .......................................... 37

Figure II-18 Multilateral well designs in Montana and North Dakota (Powell et al,

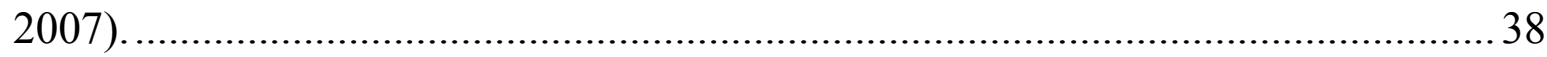

Figure II-19 Dual laterals well designs in Montana (Powell et al, 2007)........................39

Figure II-20 Tri- laterals well design in North Dakota (Powell et al, 2007).....................39

Figure II-21 Three horizontal wells drilled parallel to each other (Matthews, 2008)...... 41

Figure II-22 Transverse hydraulic fractures intersecting horizontal well (Wei and

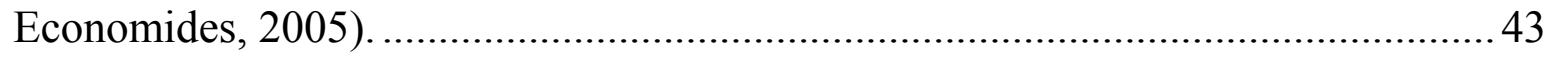

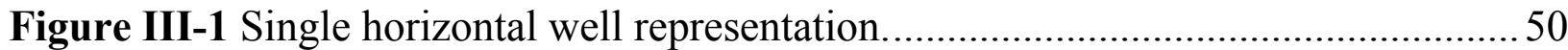

Figure III-2 Two parallel horizontal wells representation..........................................51

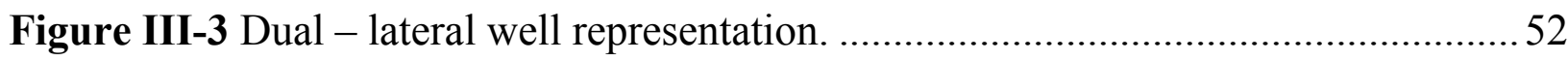

Figure III-4 V - well representation. …………........................................................... 53

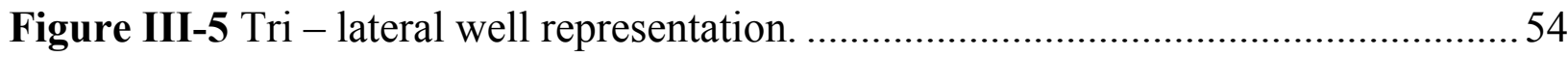

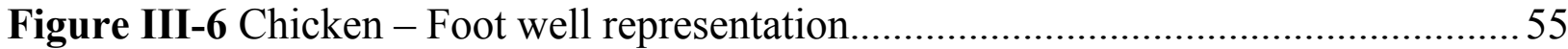

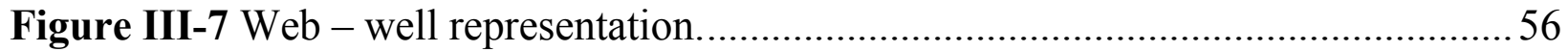

Figure III-8 Bottomhole flowing pressure versus time for a horizontal well with eight fractures treatments $(\mathrm{xf}=200 \mathrm{ft})$ tested by three different cell size limitations. .......58

Figure III-9 Bottomhole flowing pressure versus time for a Tri - lateral well with eight fractures treatments $(\mathrm{xf}=200 \mathrm{ft})$ tested by three different cell size limitations. ......59

Figure IV-1 Pseudo pressure and its derivative for the $(\mathrm{BC})$ with eight hydraulic

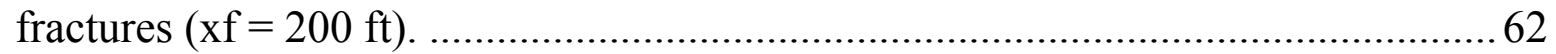

Figure IV-2 Pseudo pressure and its derivative for the (BC) without hydraulic fractures.

Figure IV-3 Pseudo pressure and its derivative for the (BC) with and without hydraulic fracture. 64

Figure IV-4 Pressure distribution for the $(\mathrm{BC})$ with eight hydraulic fractures $(\mathrm{xf}=200 \mathrm{ft})$ at the end of 30 years. 
Figure IV-5 Pressure distribution for the (BC) without hydraulic fractures (HF) at the end of 30 years.

Figure IV-6 Productivity Index versus time for the (BC) with and without hydraulic fractures.

Figure IV-7 Total production versus time for the $(\mathrm{BC})$ with and without hydraulic fractures. 68

Figure IV-8 Pseudo pressure and its derivative for the (TPHW) and the (BC) with eight fracture treatment $(\mathrm{xf}=200 \mathrm{ft})$.

Figure IV-9 Productivity Index versus time for the (TPHW) and the (BC) with eight fracture treatment $(\mathrm{xf}=200 \mathrm{ft})$. 70

Figure IV-10 Total production versus time for the (TPHW) and the (BC) with eight fracture treatment $(\mathrm{xf}=200 \mathrm{ft})$.

Figure IV-11 Pseudo pressure and its derivative for the (DLW) with eight fracture treatments $(\mathrm{xf}=200 \mathrm{ft})$. 72

Figure IV-12 Pseudo pressure and its derivative for the (DLW) and the (BC) with eight fracture treatments $(x f=200 \mathrm{ft})$. 73

Figure IV-13 Productivity Index for the (DLW) and the (BC) with eight fracture treatments $(\mathrm{xf}=200 \mathrm{ft})$. 74

Figure IV-14 Total production versus time for the (DLW) and the (BC) with eight fracture treatments $(\mathrm{xf}=200 \mathrm{ft})$.

Figure IV-15 Pseudo pressure and its derivative for the (VW) with eight fracture treatments $(\mathrm{xf}=200 \mathrm{ft})$. .75

Figure IV-16 Pseudo pressure and its derivative for the (VW) and the (BC) with eight fracture treatments $(x f=200 \mathrm{ft})$.

Figure IV-17 Productivity Index for the (VW) and the (BC) with eight fracture treatments $(\mathrm{xf}=200 \mathrm{ft})$.

Figure IV-18 Total production versus time for the $(\mathrm{VW})$ and the $(\mathrm{BC})$ with eight fracture treatments $(\mathrm{xf}=200 \mathrm{ft})$. 77 
Figure IV-19 Pseudo pressure and its derivative for the (TLW) with eight fracture treatments $(\mathrm{xf}=200 \mathrm{ft})$.

Figure IV-20 Pseudo pressure and its derivative for the (TLW) and the (BC) with eight fracture treatments $(x f=200 \mathrm{ft})$.

Figure IV-21 Productivity Index for the (TLW) and the (BC) with eight fracture treatments $(\mathrm{xf}=200 \mathrm{ft})$. 80

Figure IV-22 Total production versus time for the (TLW) and the (BC) with eight fracture treatments $(\mathrm{xf}=200 \mathrm{ft})$. 80

Figure IV-23 Pseudo pressure and its derivative for the (CFW) with eight fracture treatments $(\mathrm{xf}=200 \mathrm{ft})$. 82

Figure IV-24 Pseudo pressure and its derivative for the (CFW) and the (BC) with eight fracture treatments $(\mathrm{xf}=200 \mathrm{ft})$.

Figure IV-25 Pseudo pressure and its derivative for the (CFW) and (TLW) with eight fracture treatments $(x f=200 \mathrm{ft})$.

Figure IV-26 Productivity Index for the (CFW) and (BC) with eight fracture treatments $(\mathrm{xf}=200 \mathrm{ft})$ 83

Figure IV-27 Total production versus time for the (CFW) and the $(\mathrm{BC})$ with eight fracture treatments $(x f=200 \mathrm{ft})$. 84

Figure IV-28 Pseudo pressure and its derivative for the (WW) case with eight fracture treatments $(\mathrm{xf}=200 \mathrm{ft})$ 86

Figure IV-29 Pseudo pressure and its derivative for the (WW) and the (BC) with eight fracture treatments $(x f=200 \mathrm{ft})$. 86

Figure IV-30 Productivity Index for the (WW) and the $(\mathrm{BC})$ with eight fracture treatments $(\mathrm{xf}=200 \mathrm{ft})$. 87

Figure IV-31 Total production versus time for the (WW) and the (BC) with eight fracture treatments $(\mathrm{xf}=200 \mathrm{ft})$.

Figure IV-32 Productivity indices for the (BC) with and without HF, (TPHW), (DLW), (VW), (TLW), (CFW) and (WW). 89 
Figure IV-33 Effect of fracture half length on productivity index for a dual - lateral well

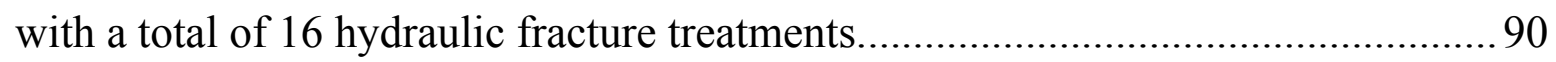

Figure IV-34 Productivity indices for the (DLW, VW and TLW) with 8 and 16 hydraulic

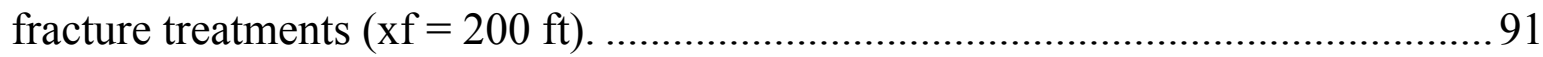

Figure IV-35 Total production versus time for the (DLW, VW and TLW) with 8 and 16

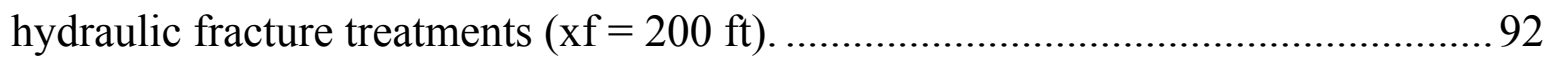




\section{LIST OF TABLES}

Table III-1 Representative reservoir data that are used to run the reservoir simulation.. 47

Table III-2 Hydraulic fracture properties that are used to run the reservoir simulation. . 48

Table III-3 Well configurations or designs used in this study........................................ 49

Table III-4 Minimum and Maximum cell size for three different trials. .........................57 


\section{CHAPTER I}

\section{INTRODUCTION}

Natural gas producing from shale reservoirs are historically represented the first source of gas production in North America. The first natural gas well was completed in Devonian Shale of Fredonia, New York on 1821 in Appalachian basin. After this first production history, the oil and gas industry moved to more producible formation and the shale remained as source rock for these conventional oil and gas resources. Also, shale plays as a good barrier for the conventional oil and gas formations, because of its very low matrix permeability in nano - darcy range $\left(\mathrm{nd}=10^{-9}\right.$ darcy). The existence of natural fractures and the organic matter content of shale, converts the shale as a prospective for an unconventional naturally fractured formations.

Productivity Index (PI) for a well is known or defined as a ratio of the well flow rate to the pressure draw down as shown below:

$$
J=\frac{q}{(\bar{P})-\left(P_{B H P}\right)}
$$

$\mathrm{q}=$ Well production rate.

$\overline{\mathrm{P}}=$ Average reservoir pressure.

$\mathrm{P}_{\mathrm{BHP}}=$ Flowing bottomhole pseudopressure. 
Productivity index has been utilized in the oil and gas industry and the academic researches as a measure for the effects of reservoir properties and different well configurations (Economides et al, 1996).

A flow regime through different well configurations is diagnosed in this study by using dimensionless pseudo pressure and dimensionless derivative. Flow from the natural fractures, matrix and the hydraulic fractures plays a major role to indicate the productivity of gas well drilled in shale formation.

Vertical wells completed with hydraulic fracture have been used to produce gas from shale formations such as Barnett Shale of Forth Worth Basin in north Texas until 2002, and then horizontal drilling technique is introduced to be a successful drilling method (Montgomery et al, 2005). Both horizontal well completion in the shale formation and the use of multi - stages slick water hydraulic fracture technique has a major rule in the booming production from the Barnett Shale of Forth Worth Basin in north Texas.

Stimulation technique by using hydraulic fracture in shale formation is a must, because of the very low permeability of shale formation. There are several hydraulic fracture techniques used in the gas shale formation such as simultaneous fracturing; this is done by fracturing two parallel horizontal wells at the same time to create and reactivate more fractures (Matthews, 2008). The other technique is sequential fracturing done by fracturing wells in a sequence order (Matthews, 2008). 
The objective of this study is to study the effect of different well configurations on the productivity index of gas wells drilled in shale formation. These well configurations have been stimulated by eight stage transverse hydraulic fractures which practiced in Barnett Shale in 2006 (Matthews, 2008). In this study the effect of stages' number on productivity index is investigated, too. The well configurations used in this study are the single horizontal well (Base case), two parallel horizontal well, dual - lateral well with two opposing laterals $\left(180^{\circ}\right.$ is the angle between the two laterals), $\mathrm{v}-$ well $\left(120^{\circ}\right.$ is the angles between the two laterals), tri - well $\left(120^{\circ}\right.$ is the angles between the three laterals), chicken foot - well $\left(60^{\circ}\right.$ is the angle between the three laterals $)$ and the web - well $\left(60^{\circ}\right.$ is the angle between the six laterals). These well configurations are modeled by using a reservoirs simulation program. Various flow regimes for these configurations are studied to determine their effect on the productivity index. Total production from the different well configurations is used to confirm the best well configuration design. 


\section{CHAPTER II}

\section{LITERATURE REVIEW}

\subsection{Gas Shale:}

Shale formation originally works as a source and as a sealing rock for hydrocarbons. In the last years the demand for natural gas and the increase in gas prices caused a shortage of energy supplies, thus driving the industry to focus on unconventional energy resources. The gas shale represents one of the major players on the unconventional resources beside coal bed methane, tight sand and oil shale.

Natural gas production from shale reservoirs is not a new discovery, but the first commercial natural gas well was drilled in the Devonian shale of Fredonia, New York in 1821 and more production was recorded in the late 1880's in the Appalachian region, again in Devonian gas shale (Matthews et al, 2007).

Figure II-1 shows the major shale basins play in the United States of America. The most successful shale formation is the Barnett Shale of Forth Worth Basin, particularly Newark East field which is the largest single daily gas producing field in Texas with annual production growth substantially higher than $10 \%$.(Bowker, 2007). 


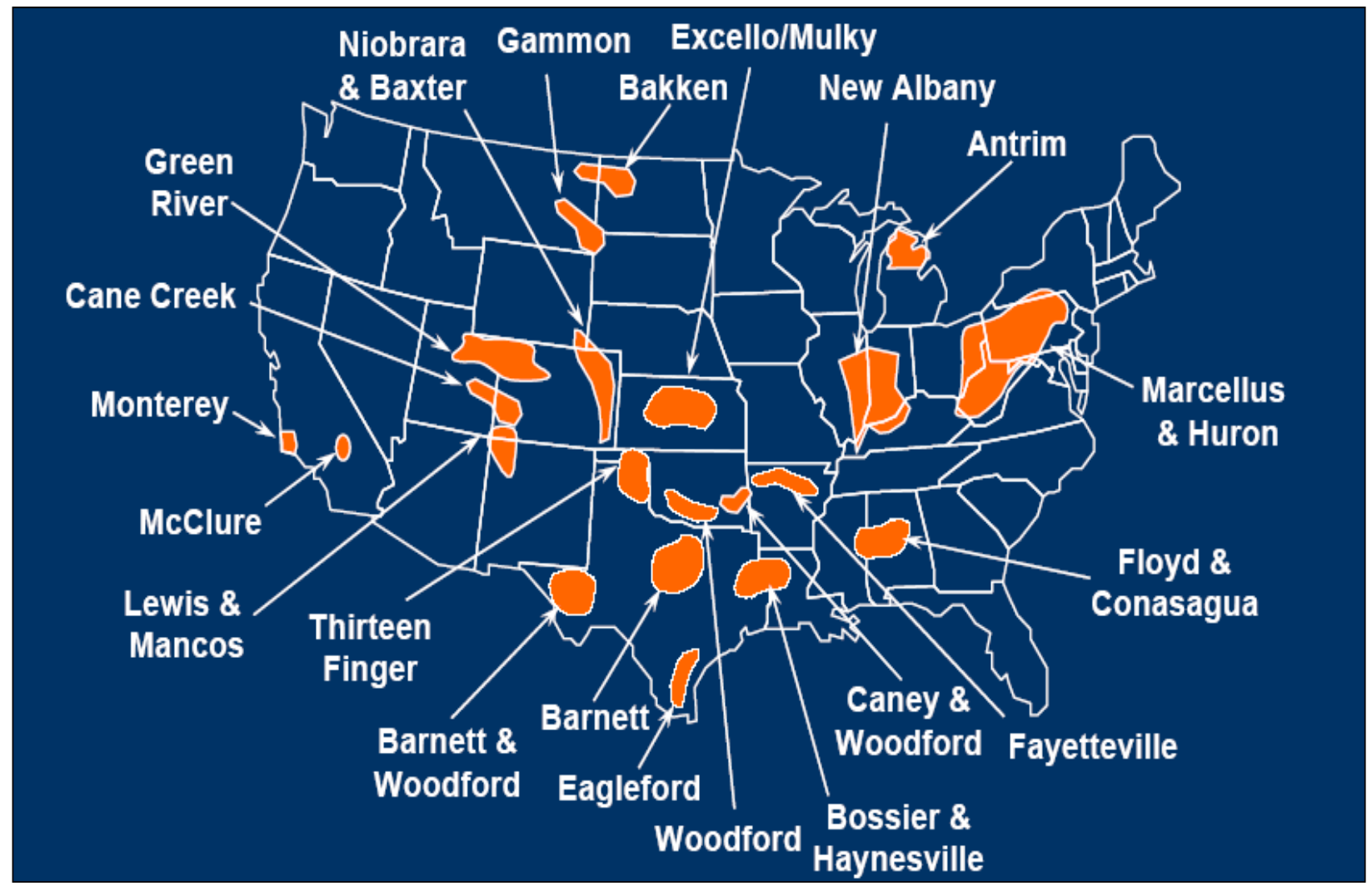

Figure II-1 Major Shale Basins Play in United States of America (Waters, 2009).

\subsubsection{Barnett Shale:}

The Barnett Shale is organic - rich, petroliferous black shale of middle - late Mississippian (Osagean - Chersterian) age. It has been known as a probable source rock for hydrocarbons throughout north - central Texas (Montgomery et al, 2005).

Shale formations are not all the same. Barnett varies from other shale formations in many points. First, the Barnett produces from greater depths which result in higher reservoir pressure. Second, Barnett gas is entirely thermogenic in origin, and occurs in large parts of the basin with liquid petroleum and multiphase thermal history, making geochemical considerations central to patterns of productivity (Montgomery et al, 2005).The progress 
in completion technique such as horizontal wells and the use of slick water as the best stimulation method in Barnett Shale represents a model for future exploitation of other gas shale plays elsewhere in the world. In the present days some of these applications in Marcellus Shale of the Appalachian Basin are observed.

\subsubsection{Gas Shale Production Mechanism:}

Gas in shale reservoirs is stored in two primary approaches:

\subsubsection{Sorption:}

It refers to gas that is stored in adsorbed and absorbed states (Montgomery et al, 2005). Adsorbed gas is held on the surfaces of solid material, either organic matter or minerals. The physical controls on adsorption include the type of solid sorbent, temperature, and the rate of gas diffusion (Montgomery et al, 2005).

Absorbed gas, however exists in a dissolved state, e.g., as a solution gas in liquid petroleum, and is controlled by pressure and temperature conditions. This state (Absorbed) has been proven to be difficult to determine absolutely the disposition of these two states in productive part of Barnett Shale (Montgomery et al, 2005). 


\subsubsection{Compression of free gas in natural fractures and Matrix porosity:}

2.1.2.2.1 Natural Fractures: The topic of open natural fractures is the most controversial among the community of Barnett Shale workers (Bowker, 2007). There are two different points of view in this argument. The first point of view by Kent A. Bowker and Scott L. Montgomery and Kent A. Bowker stated that "if there was an abundance of open natural fractures within the Barnett, there would be a much smaller gas accumulation present within the reservoir". This statement is based on, the open natural fractures leading to migration of the gas out of the shale to the overlying rocks.

The second point of view by Gale et al (2007), states that the natural fractures are generally present in a narrow aperture $(<0.002$ in), sealed with calcite and located in an echelon arrays, Figure II-2. The narrow, sealed natural fractures are not contributed to reservoir storage, but the population may follow a power law size distribution where the largest fracture is open (Gale et al, 2007). They suggested that large open fractures exist in clusters spaced several hundred feet apart. Geomechanical models using high subcritical indices show that the spacing between clusters may be two to three times the mechanical layer thickness (the mechanical layer is the shale thickness).

The natural fractures either sealed or open can reactivate during the hydraulic fracturing treatment, creating a large rock volume in contact with the wellbore; as the case with a single hydraulic fracture. The sealing materials in the fractures are not generally 
template onto grains in the wall rock, and the natural fractures act as planes of weakness that can be reactivated by induced fracture (Gale et al, 2007).

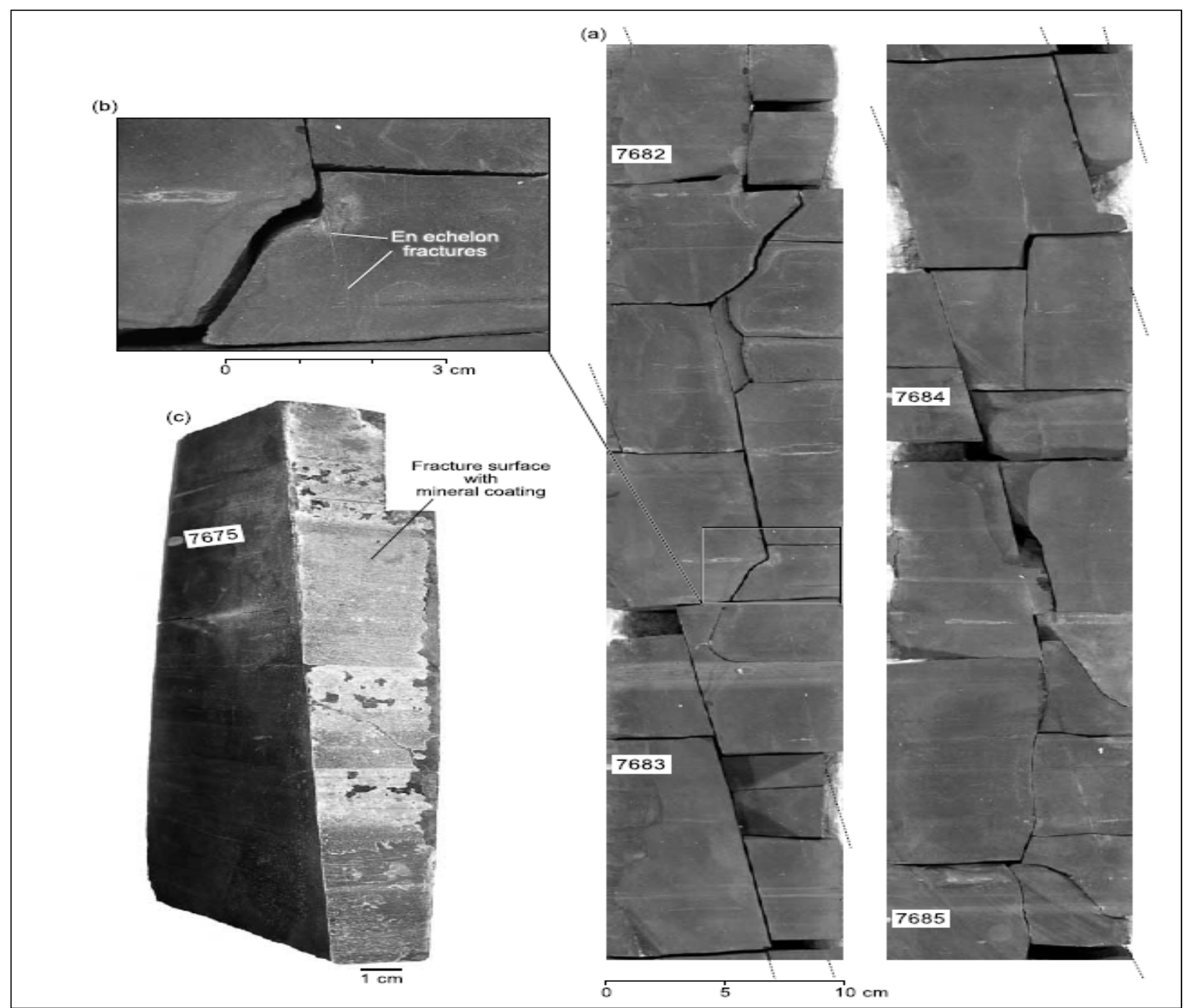

Figure II-2 Natural fractures in the T.P.Sims core, Barnett Shale (Gale et al, 2007). 
2.1.2.2 2 Matrix Porosity: Some geoscientists believe that $50 \%$ of the gas at Newark East Field in east Texas is stored in the matrix porosity ( Bowker, 2007), and there is growing thought that more than $50 \%$ of the gas in place in the Barnett Shale of Newark East Field is in the matrix porosity. The organic rich part of the Barnett has an average porosity of $5.5 \%$.

It is believed that the production mechanism of shale gas is a combination of gas stored in open natural fractures and matrix porosity ( $>50 \%$ of the gas in place). The second production mechanism is due to the gas adsorbed in the shale surface similar to coal bed methane. Thus, shale reservoir is considered as a Dual Porosity Reservoir. Figure II-3 (Waters, 2009).

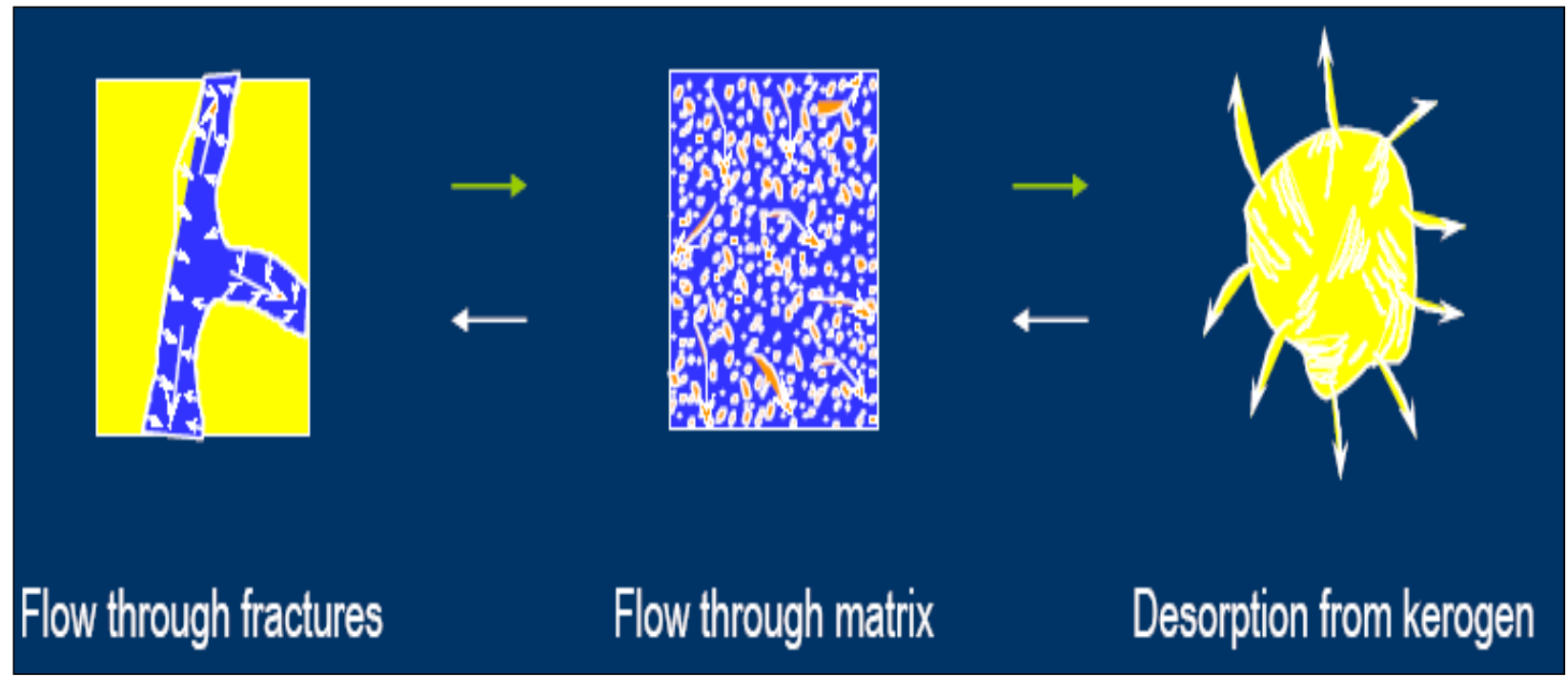

Figure II-3 Shale Reservoir Production Mechanism (Waters, 2009). 


\subsubsection{Gas Content:}

Gas content has a primary role in the production of unconventional natural gas (Coal Bed Methane) and it is measured as gas yield per mass of rock (Montgomery et al, 2005).

Gas content refers to the determination of the total adsorbed or absorbed gas and this determination has relied on desorption studies on core samples. Onsite and laboratory desorption tests have been performed on core samples collected both by conventional and pressure coring equipment. Figure II-4 shows values of methane isotherms; based on data reworked for the T.P.Sims 2 well (Wise County, Newark East Field (Montgomery et al, 2005). The isotherm covers both adsorbed and total gas.

The adsorbed gas ranges from $60-125 \mathrm{scf} / \mathrm{t}$ at a reservoir pressure of $3800 \mathrm{psia}$. The average value is $85 \mathrm{scf} / \mathrm{t}$ for adsorbed gas and $105 \mathrm{scf} / \mathrm{t}$ for free gas, representing approximately $45 \%$ and $55 \%$ of the average total gas (190 scf/t), respectively. 


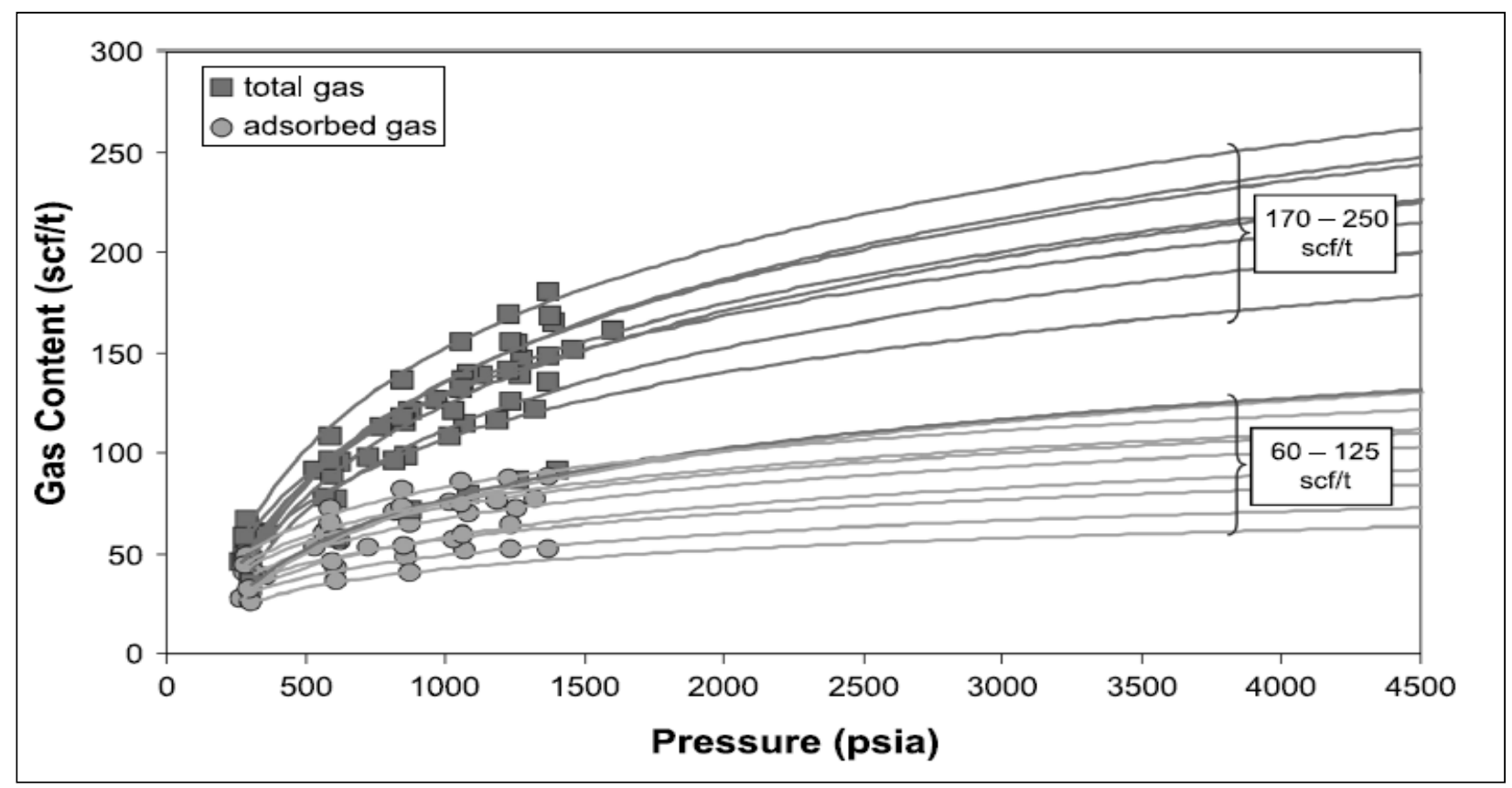

Figure II-4 Adsorption isotherms for Barnett Shale core samples (Montgomery et al, 2005).

\subsubsection{Gas Transmission:}

The permeability of shale is generally very low and it is measured in nano darcy (nd $=10^{-}$

${ }^{9}$ darcy). The critical permeability values for gas shale must be greater than $100 \mathrm{nd}$ (Waters, 2009).

The measurements of permeability and diffusivity are done by using core samples, since the wire line logs do not directly determine permeability and diffusivity in the Barnett Shale (Bowker, 2007). 


\subsection{Natural Fracture Reservoir Models:}

The majority of very low permeability reservoirs are naturally fractured; these natural fractures make the exploitation of these tight formations possible with the application of hydraulic fracturing technology.

Warren and Root (Warren and Root, 1963) introduced an analysis of the natural fracture reservoirs and they came up with the concept of two porosity system (Dual - Porosity System). Figure II-5 depicts an actual dual porosity reservoir created with a rock matrix surrounded by an irregular system of vugs and natural fractures. The theory behind their model is the two different interconnected flow behaviors present - one in the natural fracture and the other in the matrix. They found out that the real heterogeneous, dual porosity reservoir can be modeled with an equivalent homogeneous, dual - porosity such as that shown in the idealized Figure II-5.

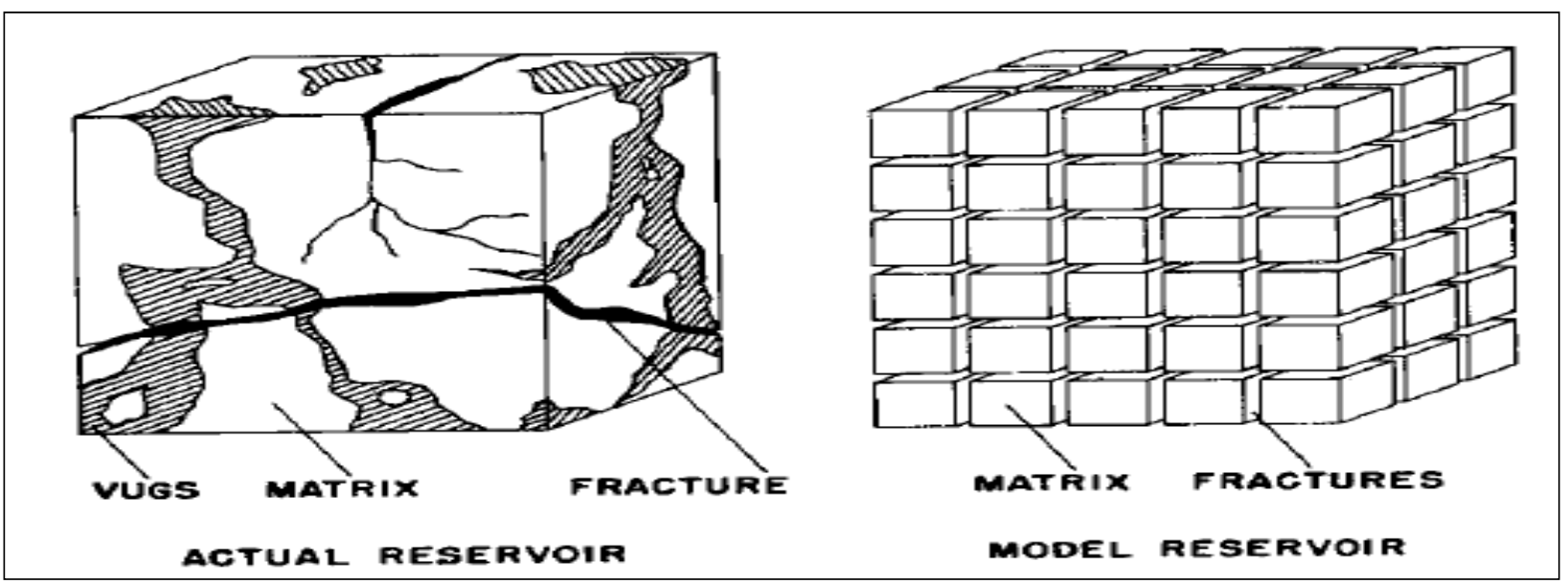

Figure II-5 Warren and Root, Dual - Porosity Model (Warren and Root, 1963). 
The natural fracture network provides the major path for the fluid flow, due to their high permeability values, however they have low porosities. The matrix represents the major storage for the reservoir but it has a very low permeability making the production from the matrix very difficult and in fact the production is not possible without the existence of natural fractures.

Warren and Root (1963) acquainted the industry with two parameters to describe the deviation of the behavior of the reservoir with Dual - Porosity from that of a homogeneous porous medium.

The first parameter is interporosity flow coefficient $(\lambda)$ Figure II- 6 , which measures how easily fluid flows from the matrix to the natural fractures, and is given as:

$$
\lambda=\alpha r_{w}^{2}\left(\frac{k_{m a}}{k_{f}}\right)
$$

And

$$
\alpha=\frac{4 \mathrm{j}(\mathrm{j}+2)}{\mathrm{L}^{2}} .
$$

Where the terms are defined as:

$\mathrm{k}_{\mathrm{ma}}=$ Matrix Permeability, $\mathrm{L}^{2}$, md.

$\mathrm{k}_{\mathrm{f}}=$ Natural fracture permeability, $\mathrm{L}^{2}$, $\mathrm{md}$.

$\mathrm{L}=$ Characteristic dimension of a matrix block, $\mathrm{L}, \mathrm{ft}$. 
$\mathrm{j}=$ Number of normal sets of natural fracture planes limiting the matrix medium.

$\mathrm{j}=3$, in Figure II -5.

The second parameter is the storativity ratio $(\omega)$ Figure II-7, that measures the fluid capacitance of the natural fracture.

$$
\omega=\frac{\left(\phi c_{t}\right)_{\mathrm{f}}}{\left(\phi c_{t}\right)_{\mathrm{f}}+\left(\phi c_{t}\right)_{m a}} .
$$

The terms used in the equations are defined as:

$\phi=$ Porosity, Dimensionless

$\mathrm{c}_{\mathrm{t}}=$ Total compressibility, $\mathrm{m} / \mathrm{Lt}, \mathrm{psi}^{-1}$

$\mathrm{f}=$ Natural Fracture.

ma $=$ Matrix 


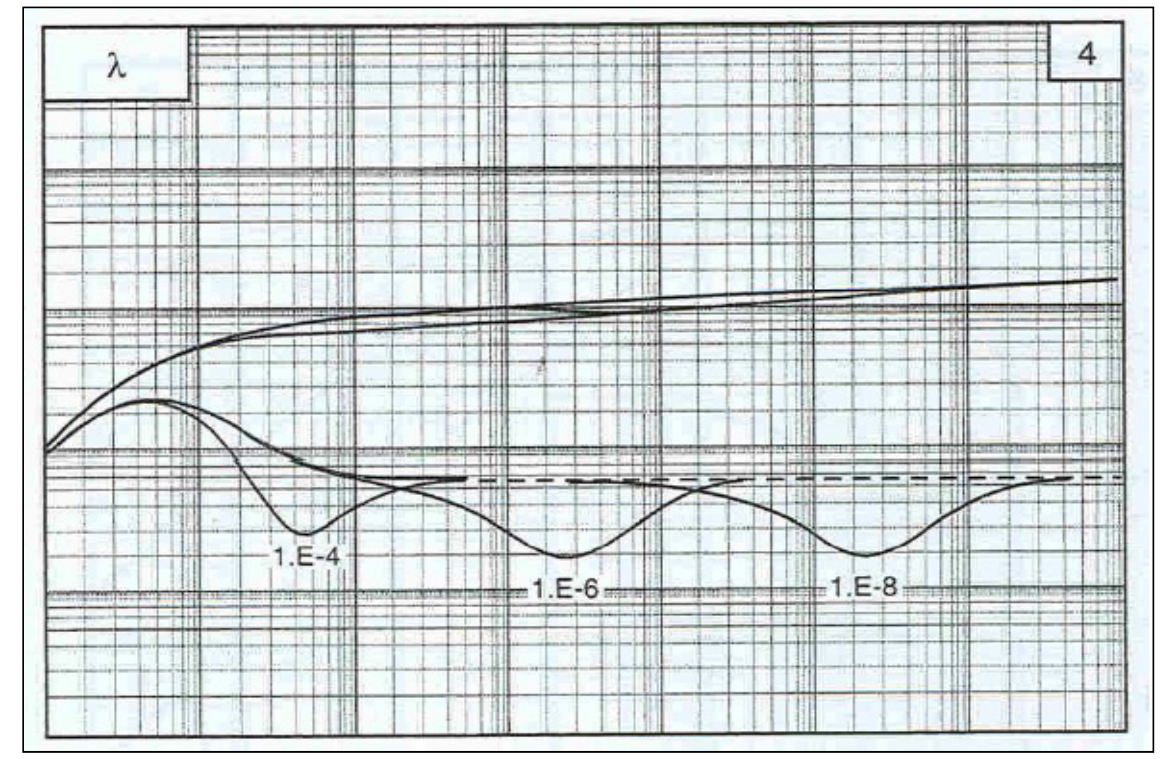

Figure II-6 Type curve (Pressure and pressure derivative versus time) for dual - porosity reservoirs with different values for $\lambda$ (Well Test Interpretation, Schlumberger 2002).

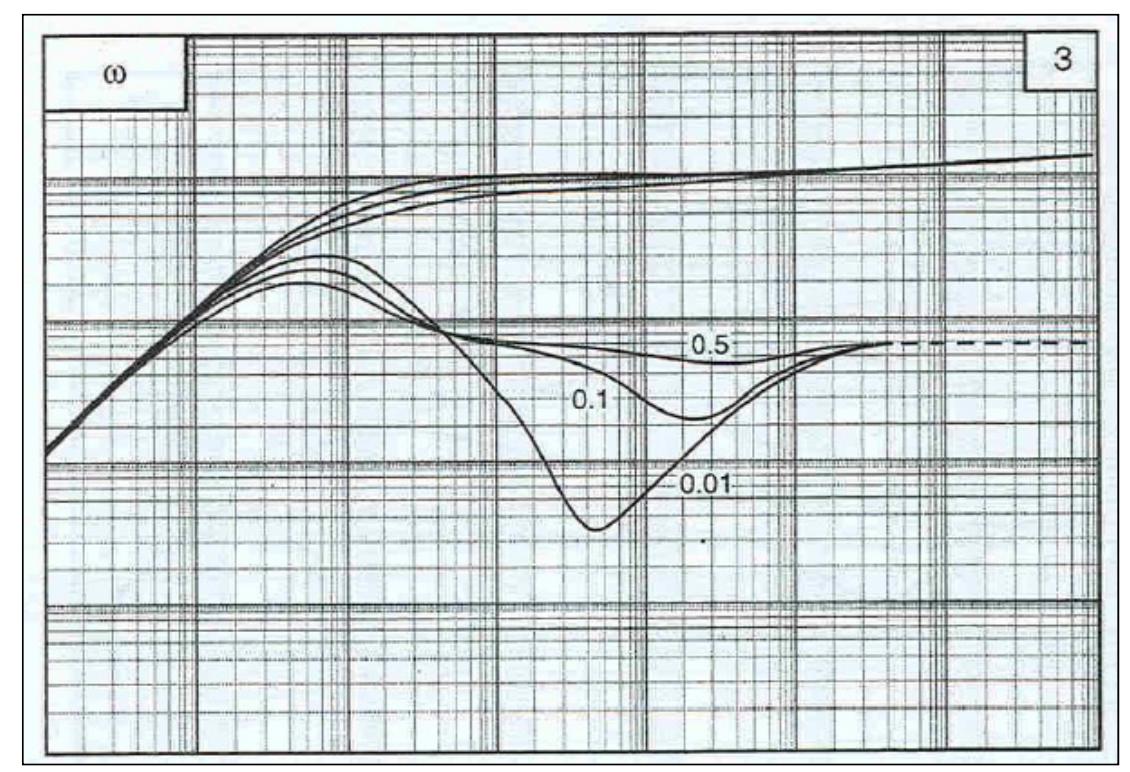

Figure II-7 Type curve (Pressure and pressure derivative versus time) for dual - porosity reservoirs with different values for $\omega$ (Well Test Interpretation, Schlumberger 2002). 
There are two models currently used to represent the flow from the matrix to the natural fractures. The first flow model is Pseudo - Steady state flow from the matrix to natural fractures (Barenblatt et al, 1960) and (Warren and Root, 1963).

The second flow model is Unsteady - State flow, (Kazemi, 1969), (DeSwaan, 1976), (transient flow) in the matrix. Figure II-8 depicts Kazemi model and compares it with Warren and Root.

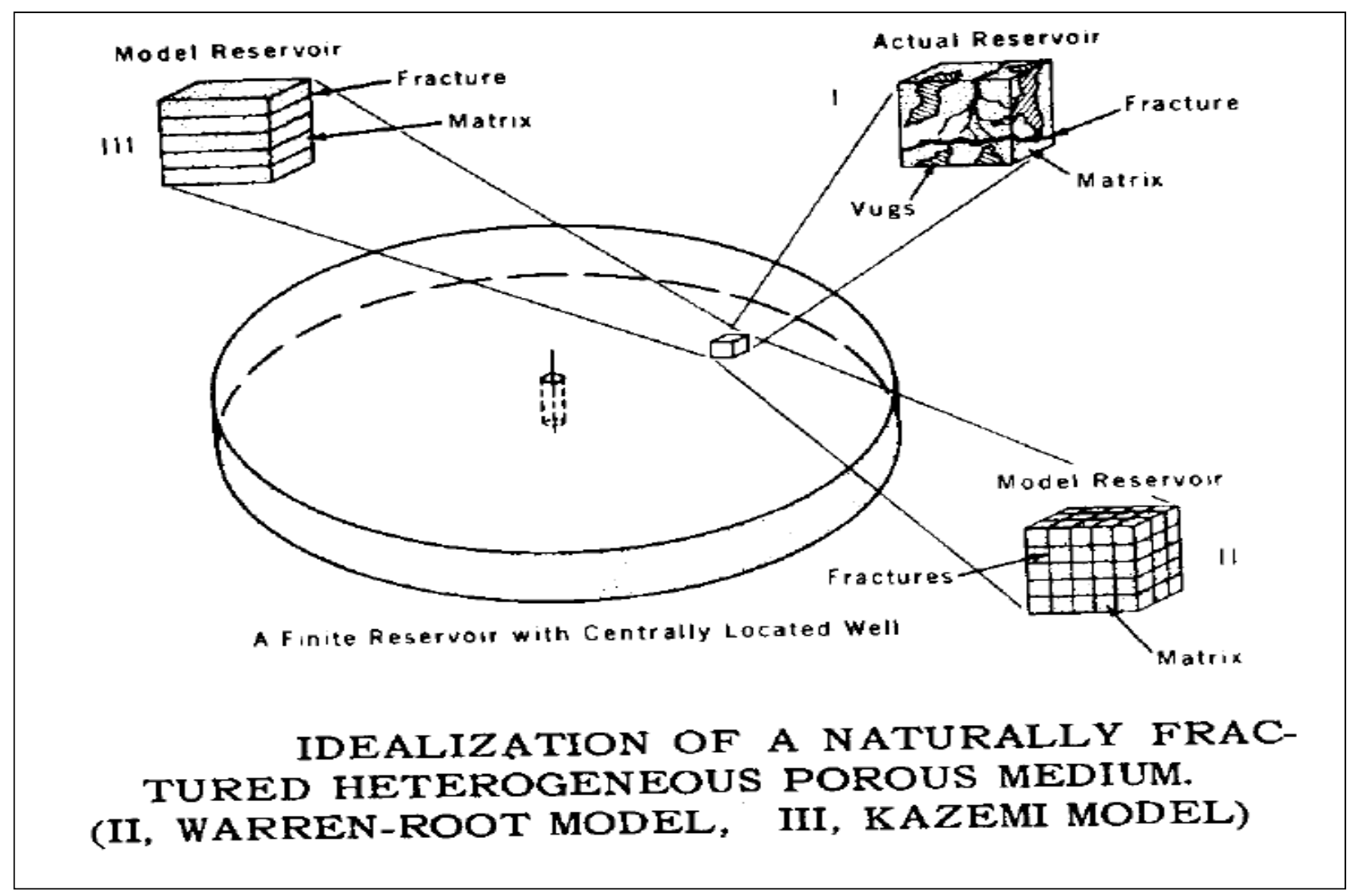

Figure II-8 Kazemi model \& Warren and Root model (Kazemi, 1969). 


\subsection{Productivity Index of Fractured Horizontal Gas Wells in Naturally Fractured Reservoirs (Dual - Porosity Reservoirs):}

\subsubsection{Medeiros F., Ozkan E. and Kazemi H. Model:}

Medeiros, Ozkan and Kazemi (2008), addressed the performance and productivity index of fractured horizontal wells in heterogeneous (naturally fractured), tight gas formations using semianalytical model. The main target of this model is to study the amalgamation effects of a dual - porosity region and hydraulic fractures on the productivity index of horizontal wells.

This semianalytical model is developed based on the work done by (Medeiros et al, 2006). The model used to include finite conductivity hydraulic fractures (transverse and longitudinal) along horizontal well and naturally fractured zones surrounded the hydraulically fractured horizontal wells by using of dual porosity idealization Figure II-9. 

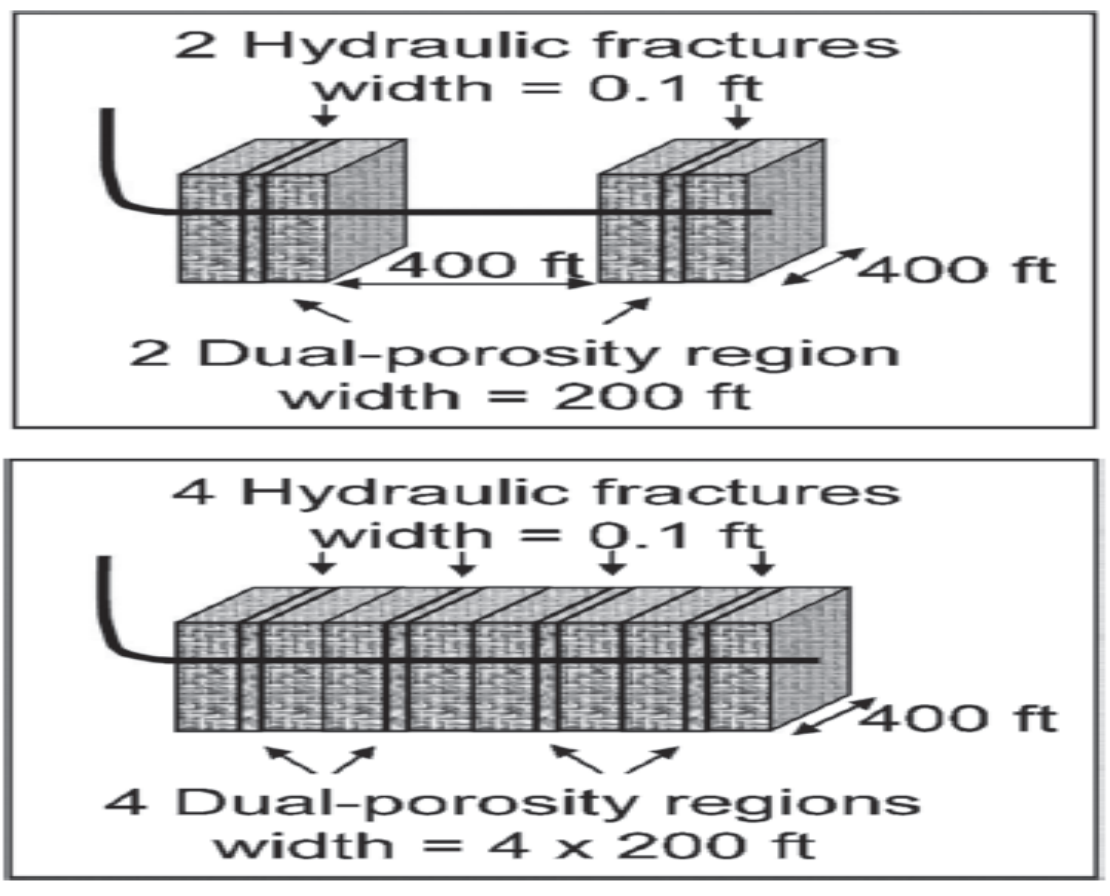

Figure II-9 Horizontal well with transverse fractures surrounded by dual - porosity regions (Medeiros et al, 2008).

The semianalytical model is based on the solution of the $3 \mathrm{D}$ diffusivity equation (Equation II-4) in terms of gas pseudo pressure. Transient (Unsteady state) solution was considered to solve the diffusivity equations, because horizontal wells in tight formations stay longer in transient - flow period before going to depletion under the influence of boundaries.

$$
\mathrm{k}_{\mathrm{x}} \frac{\partial^{2} \Delta \mathrm{m}(\mathrm{p})}{\partial \mathrm{x}^{2}}+\mathrm{k}_{\mathrm{y}} \frac{\partial^{2} \Delta \mathrm{m}(\mathrm{p})}{\partial \mathrm{y}^{2}}+\mathrm{k}_{\mathrm{z}} \frac{\partial^{2} \Delta \mathrm{m}(\mathrm{p})}{\partial \mathrm{z}^{2}}=\phi \mu \mathrm{c}_{\mathrm{t}} \frac{\partial \Delta \mathrm{m}(\mathrm{p})}{\partial \mathrm{t}}
$$


The pseudo pressure is given by:

$$
\begin{aligned}
& \mathrm{m}(\mathrm{p})=2 \int_{0}^{\mathrm{p}} \frac{\mathrm{p}^{\prime}}{\mu \mathrm{Z}} \mathrm{dp} \mathrm{p}^{\prime} \ldots \ldots \ldots \\
& \Delta \mathrm{m}(\mathrm{p})=\mathrm{m}\left(\mathrm{p}_{\mathrm{i}}\right)-\mathrm{m}(\mathrm{p}) .
\end{aligned}
$$

The semianalytical model requires that the reservoir to be subdivided into homogeneous blocks; the solution is done for each block using Green's function (Gringarten et al, 1973); (Ozkan and Raghavan, 1991a and 1991b). Hydraulic fractures are modeled along the well as thin blocks with the properties of the fractures. Natural fractured regions can be modeled by using the dual - porosity idealization of Warren and Root (1963) or Kazemi (1969) for the appropriate blocks. Medeiros et al (2008) used the dual - porosity parameters introduced by Warren and Root (1963), except the shape factor sigma $(\sigma)$. The storativity ratio and interporosity flow coefficient are defined, respectively:

$$
\omega=\frac{\left(\phi c_{\mathrm{t}}\right)_{\mathrm{f}}}{\left(\phi c_{\mathrm{t}}\right)_{\mathrm{f}}+\left(\phi c_{\mathrm{t}}\right)_{\mathrm{ma}}} .
$$

And

$$
\lambda=\sigma \mathrm{l}_{\mathrm{ref}}^{2}\left(\frac{\mathrm{k}_{\mathrm{ma}}}{\mathrm{k}_{\mathrm{f}}}\right) .
$$

The geometric shape factor is defined by (Kazemi et al, 1976), and is given by:

$$
\sigma=4\left(\frac{1}{\mathrm{~L}_{\mathrm{x}}^{2}}+\frac{1}{\mathrm{~L}_{\mathrm{y}}^{2}}+\frac{1}{\mathrm{~L}_{\mathrm{Z}}^{2}}\right) \ldots
$$


Where:

$l_{\text {ref }}=$ reference length, $\mathrm{ft}$.

$\mathrm{L}_{\mathrm{x}}, \mathrm{L}_{\mathrm{y}}, \mathrm{L}_{\mathrm{z}}=$ the dimensions of the matrix block in $\mathrm{x}, \mathrm{y}$ and $\mathrm{z}$ directions, $\mathrm{L}, \mathrm{ft}$. 


\subsubsection{Transient Productivity Index:}

The transient productivity index is a suitable tool to discuss the productivities of horizontal wells in tight formations (Medeiros et al, 2008). The use of this tool in the decline type curve analysis of horizontal wells has been discussed by (Araya and Ozkan, 2002). The generalized transient productivity index concept is useful for all modes of production (constant and variable rate, including shut - in), and it can be extended to oil producing wells (Medeiros et al, 2008). Variable rate production equations are used to develop the transient productivity index for gas flow as a function of flow rate and pseudo pressure as defined by:

$$
J(t)=\frac{\mathrm{q}_{\mathrm{sc}}(\mathrm{t})}{\Delta \mathrm{m}(\mathrm{p})-\Delta \mathrm{m}(\overline{\mathrm{p}})}=\frac{\mathrm{q}_{\mathrm{sc}}(\mathrm{t})}{\Delta \mathrm{m}(\mathrm{p})-\frac{2.356 \mathrm{Tq}_{\mathrm{sc}} \mathrm{t}_{\mathrm{a}}}{\phi\left(\mu \mathrm{c}_{\mathrm{t}}\right)_{\mathrm{i}} \mathrm{Ah}}} \ldots \ldots \ldots . . .
$$

Where:

$$
\begin{aligned}
& \Delta \mathrm{m}(\mathrm{p})=\mathrm{m}\left(\mathrm{p}_{\mathrm{i}}\right)-\mathrm{m}(\mathrm{p}) . \\
& \Delta \mathrm{m}(\overline{\mathrm{p}})=\mathrm{m}\left(\mathrm{p}_{\mathrm{i}}\right)-\mathrm{m}(\overline{\mathrm{p}}) . \\
& \mathrm{A}=\text { drainage area, } \mathrm{ft}^{2} . \\
& \mathrm{c}_{\mathrm{t}}=\text { total compressibility of the reservoir, } \mathrm{psi}^{-1} . \\
& \mathrm{h}=\text { reservoir thickness, } \mathrm{ft} . \\
& \mathrm{J}=\text { productivity index, } \mathrm{Mscf} / \mathrm{psi}^{2} / \mathrm{cp} .
\end{aligned}
$$




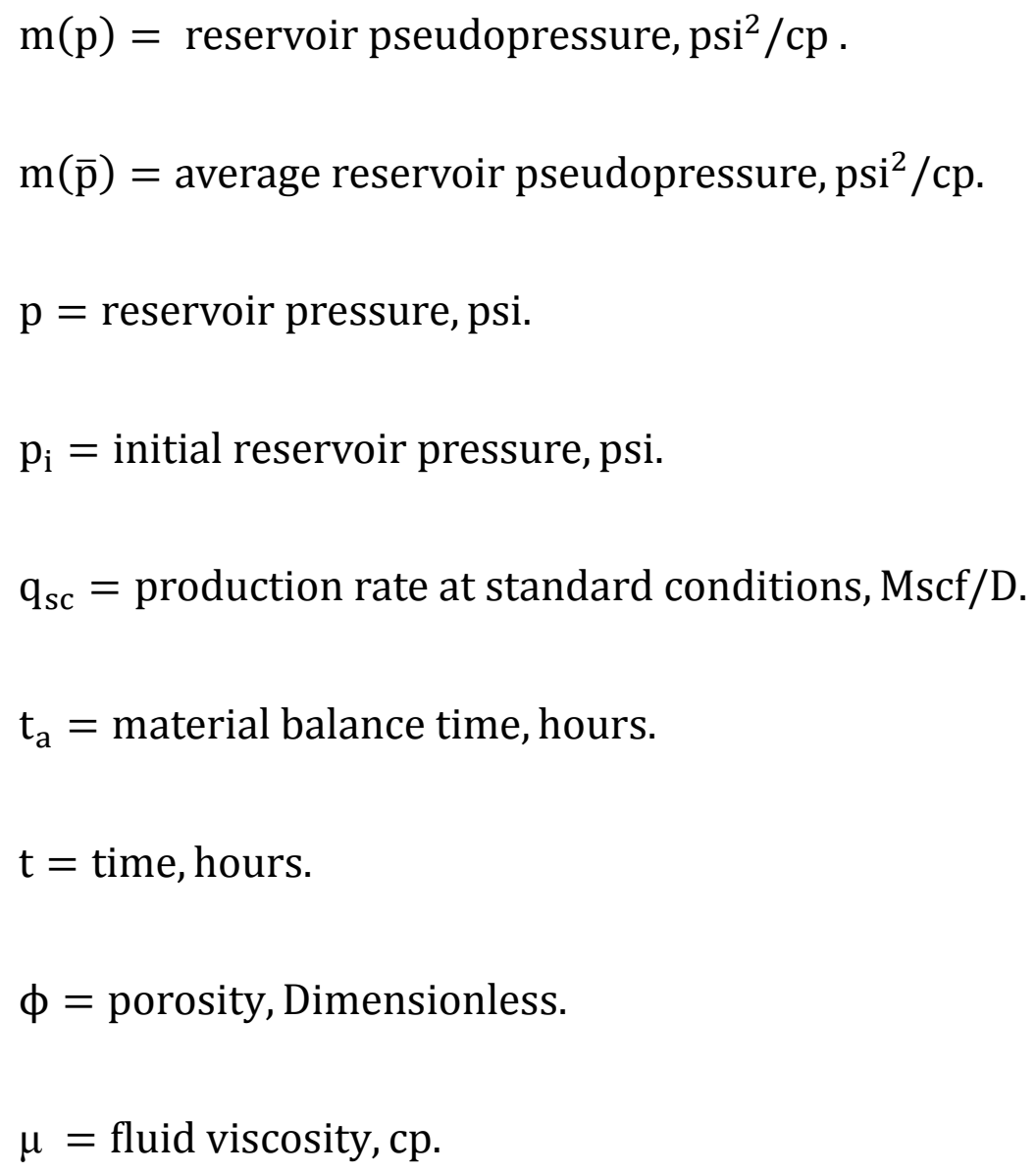

Medeiros et al (2008) introduced another parameter as the cumulative productivity index defined by:

$$
J_{c}(t)=\int_{0}^{t} J\left(t^{\prime}\right) d t^{\prime}=\int_{0}^{t} \frac{q\left(t^{\prime}\right)}{\Delta m(\bar{p})} d t^{\prime}=\frac{1}{\overline{\Delta m(\bar{p})}} \int_{0}^{t} q\left(t^{\prime}\right) d t^{\prime}=\frac{Q(t)}{\overline{\Delta m(\bar{p})}} \ldots \ldots \ldots
$$

Where:

$\mathrm{Q}(\mathrm{t})=$ cumulative production at time $(\mathrm{t})$.

$\overline{\Delta \mathrm{m}(\overline{\mathrm{p}})}=$ the integral mean value of the drawdown in the time interval 
from 0 to $(\mathrm{t})$.

The cumulative productivity index can be defined as a measure of cumulative production per average drawdown. 


\subsubsection{Trilinear - Flow Model (Ozkan et al 2009):}

This model is introduced form the observation that the drainage volume of multiply fractured - horizontal - wells is limited to inner reservoir linear flow between the fractures even for relatively large matrix permeability.

The main concept of Trilinear - flow model is that, there are three immediate flow regions as shown in Figure II-10:

- The outer reservoir $(\mathrm{O})$.

- The inner reservoir between the natural fractures (I).

- Hydraulic fracture region (F).

To simulate the performance of horizontal wells with multiple fracture treatments in shale, the authors made the inner reservoir to be naturally fractured. They used the dual porosity idealization to depict the dual - porosity region. They considered in this model transient fluid flow from the matrix $(\mathrm{m})$ to natural fractures $(\mathrm{F})$ as idealized by Kazemi (1969) and DeSwaan (1976). 


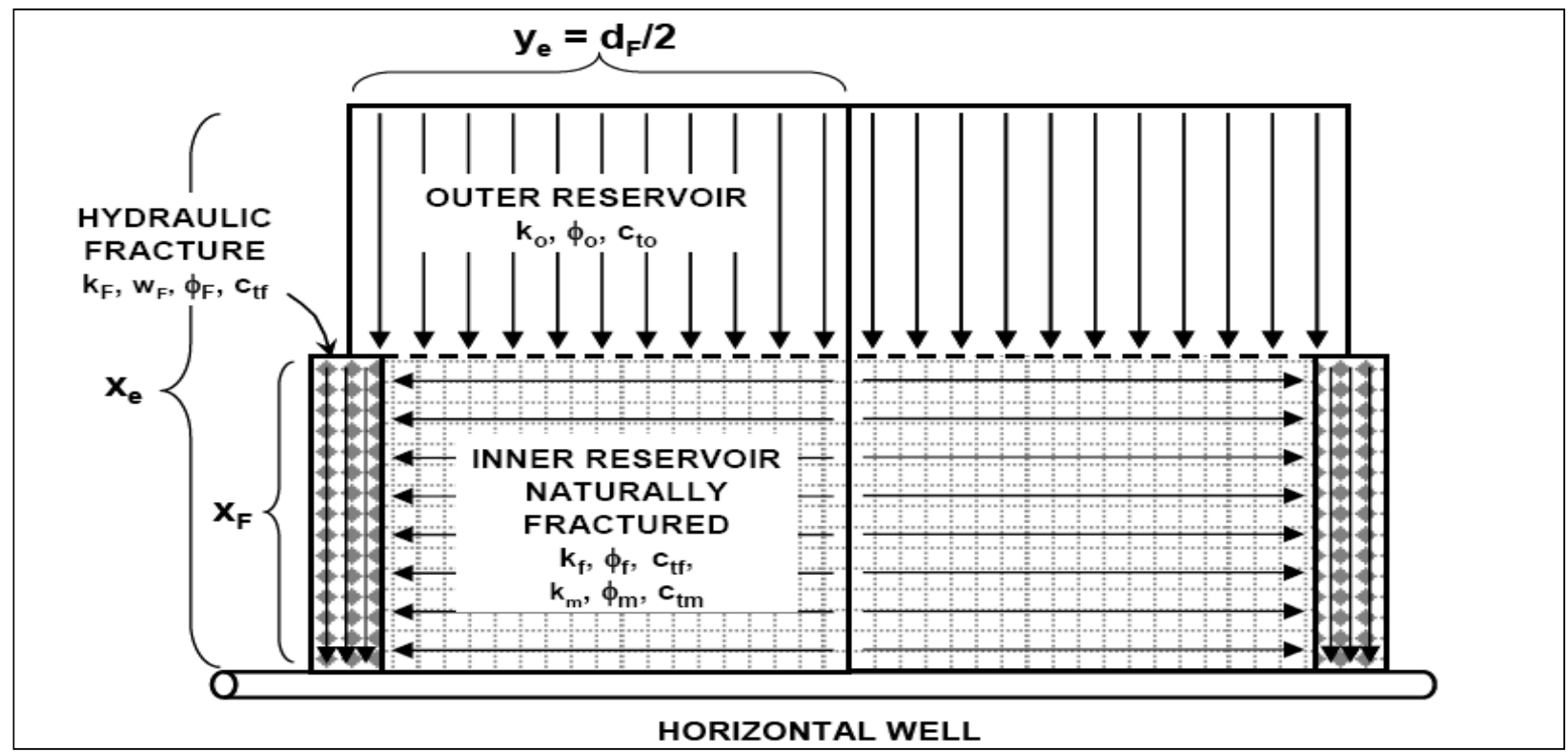

Figure II-10 Schematic of the Trilinear - flow model used for the analytical solution of multiplies - fractured - horizontal well performance (Ozkan et al, 2009).

\subsubsection{Productivity Index of the Multiply - Fractured Horizontal Gas Well:}

Constant rate production equations are used to develop the productivity index for this

case as:

$$
\begin{aligned}
& \mathrm{J}=\frac{\mathrm{q}_{\mathrm{sc}}}{\mathrm{m}(\overline{\mathrm{p}})-\mathrm{m}\left(\mathrm{p}_{\mathrm{wf}}\right)}=\mathrm{n}_{\mathrm{F}} \frac{\mathrm{q}_{\mathrm{F}}}{\frac{1422 \mathrm{q}_{\mathrm{F}} \mathrm{T}}{\mathrm{K}_{\mathrm{I}} \mathrm{h}}\left(\mathrm{m}\left(\mathrm{p}_{\mathrm{wD}}\right)-\overline{\left.\mathrm{m}\left(\mathrm{p}_{\mathrm{D}}\right)\right)}\right.} . \\
& \widetilde{\mathrm{m}\left(\mathrm{p}_{\mathrm{D}}\right)} \approx 2 \pi \frac{\mathrm{t}_{\mathrm{D}}}{(1+\omega) \mathrm{A}_{\mathrm{D}}} \ldots \ldots \ldots \ldots \ldots \ldots \ldots \ldots \ldots \ldots \ldots \ldots \ldots \ldots \ldots \ldots \ldots \ldots \ldots \ldots
\end{aligned}
$$

$\mathrm{m}\left(\mathrm{p}_{\mathrm{wD}}\right)=$ the dimensionless (pseudopressure) trilinear flow solution.

$\mathrm{q}_{\mathrm{sc}}=$ production rate at standard conditions, Mscf/D. 


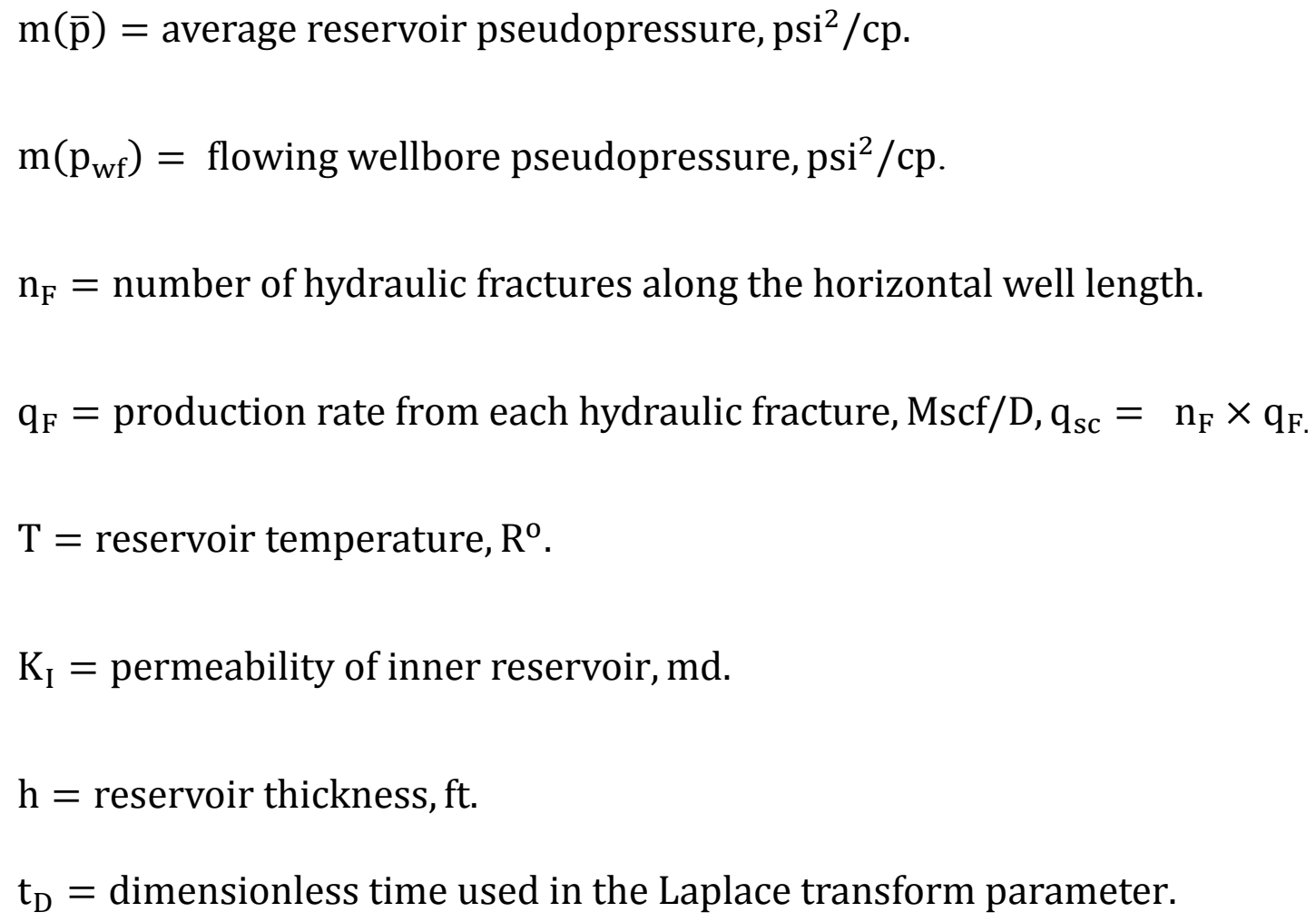




\subsection{Flow Regimes of Horizontal wells in Naturally Fractured Reservoirs:}

\subsubsection{Medeiros F., Ozkan E. and Kazemi H.:}

Medeiros et al (2006) discussed the pressure - transient characteristics of both fractured and unfractured horizontal well (HW) in both homogeneous formation and heterogeneous (Dual porosity) formation. Figure II-11 shows pseudopressure and derivative responses for an unfractured horizontal well in homogeneous tight formation. There are four flow regimes indicated in Figure II-11:

1. Early - Time Radial Flow (ERF); indicated by the flat derivative responses with $($ slope $=0)$.

2. Intermediate - Time Linear Flow (ILF); indicated by the derivative responses with $($ slope $=1 / 2)$.

3. Pseudo - Radial Flow (PRF); indicated by the derivative responses with (slope $=0)$.

4. Boundary Dominated Flow (BDF); indicated by the derivative responses with $($ slope $=1)$. 


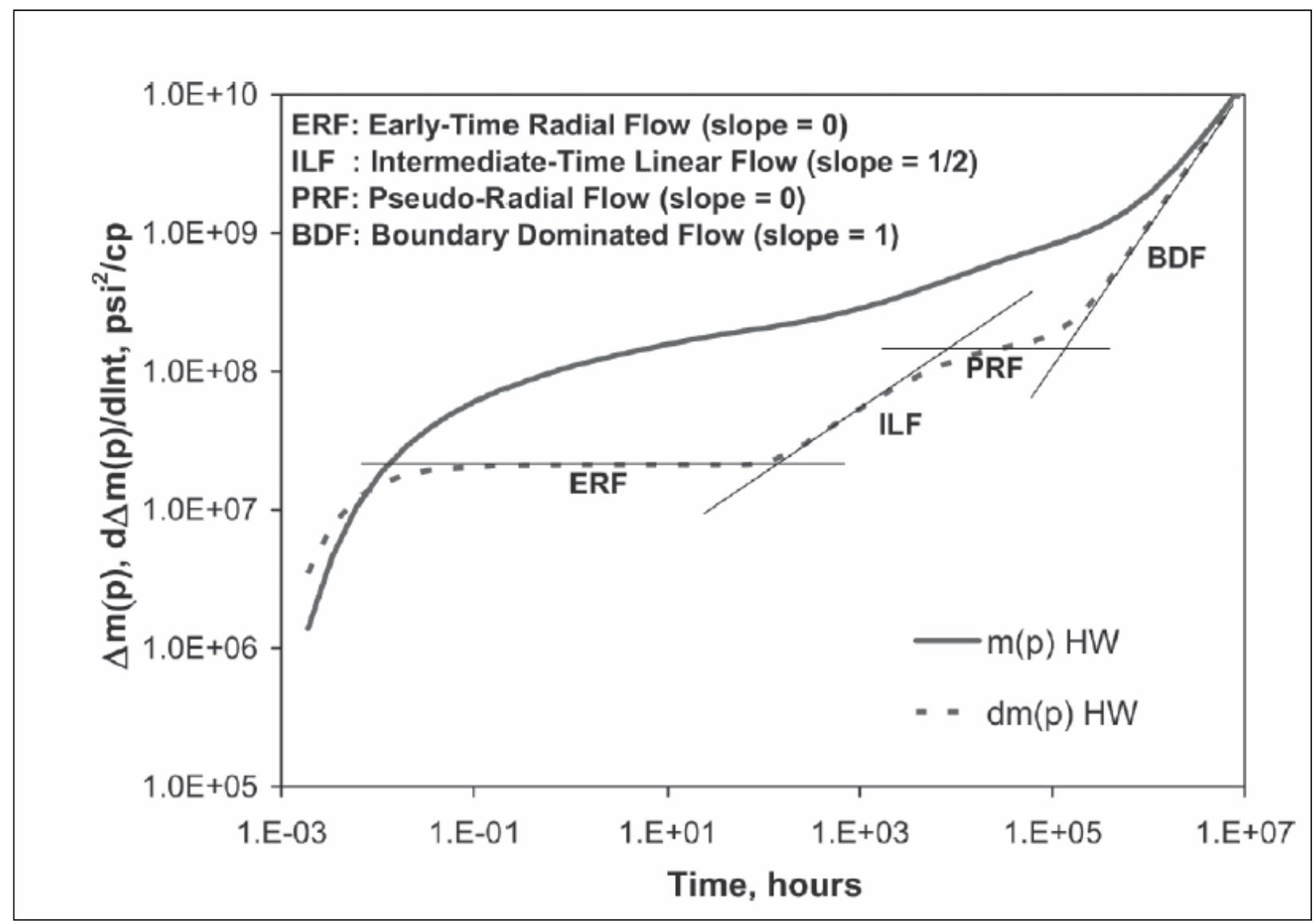

Figure II-11 Pseudopressure and derivative responses for a horizontal well in a homogeneous, tight formation (Medeiros et al, 2008).

Figure II-12 shows pseudopressure and derivative responses for a horizontal well surrounded by a naturally fractured zone (NF). The pseudopressure and pseudopressure derivative responses for the homogeneous tight formations are plotted here by the continuous and dashed lines for pseudopressure and pseudopressure derivative, respectively. The responses indicated by the filled in (pseudopressure) and open (pseudopressure derivative) square markers are for the horizontal well surrounded by natural fractures zone (NF). 


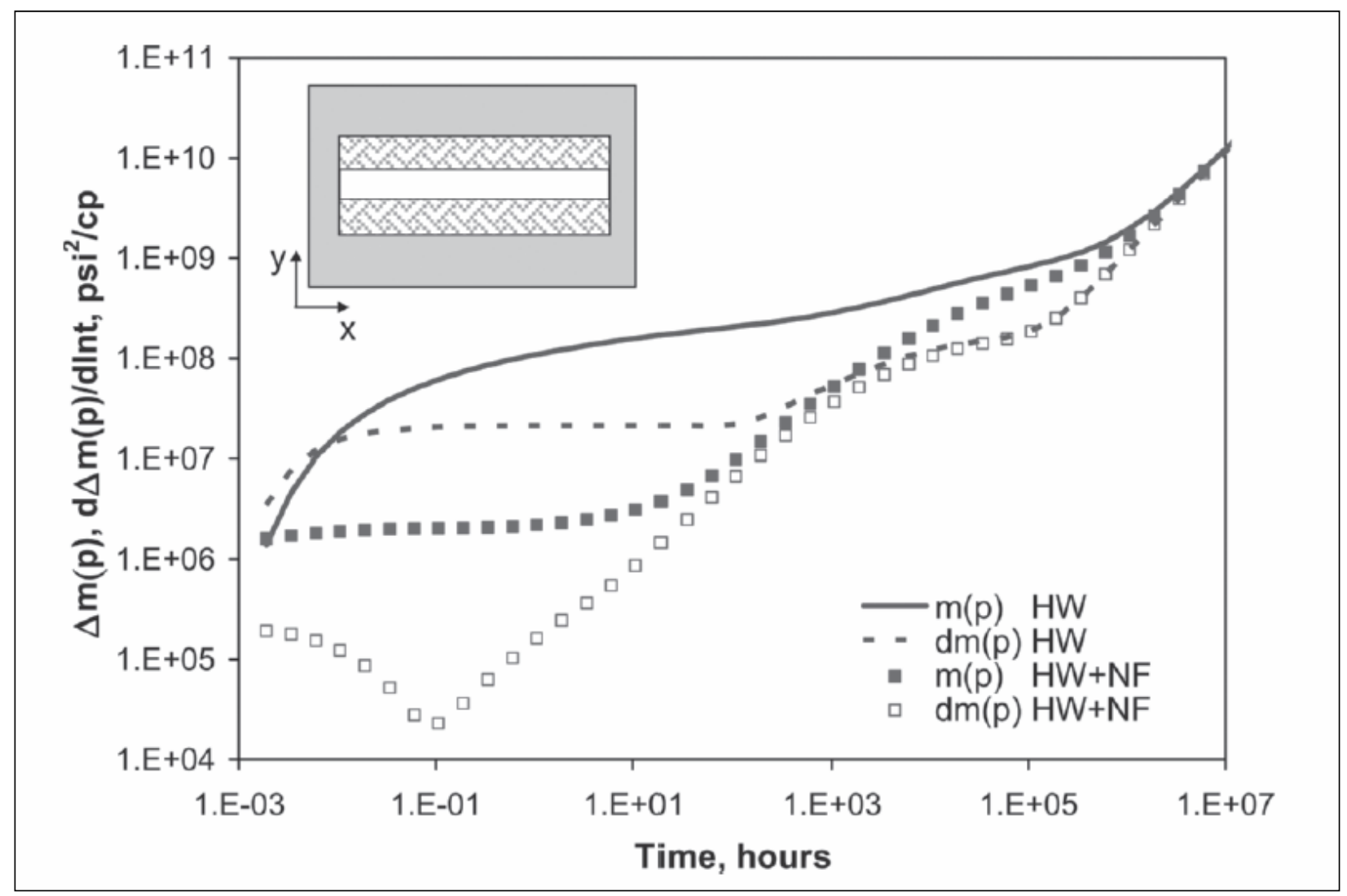

Figure II-12 Pseudopressure and derivative responses for a horizontal well surrounded by a naturally fractured zone (Medeiros et al, 2008).

Figure II-13 shows the pseudopressure and derivative responses for a horizontal well with two transverse hydraulic fractures. The flat derivative responses at early times indicate radial/linear flow (radial flow in the fracture and linear flow in the reservoir), and half slope derivative behavior indicates the reservoir linear flow toward fracture surfaces. 
Comparison of the derivative responses for the fractured and unfractured wells in Figure II-13 indicates that linear - flow behavior (half slope line derivative) ends for the fractured well before it starts for the unfractured well. This is because the linear flow for the fractured well is toward the transverse fractures (TF) and for the unfractured well it is toward the horizontal wellbore (HW) axis (Medeiros et al, 2008). The flattening of the derivatives in Figure II-13 resulted from the development of (PRF) around fractures for a short period of time, but the interference among the fractures and horizontal well masks this intermediate time PRF. Approximately at the 5.7 years $\left(5 \times 10^{4}\right.$ hours $)$, PRF around the fractured horizontal well begins. The PRF ends approximately at the 11.4 years $\left(10^{5}\right.$ hours $)$ and the influence of the boundary begins.

Similar to the unfractured - well case Figure II-12, the fractured horizontal well produces under transient flow conditions for approximately 11.5 years, $\left(10^{5}\right.$ hours $)$. During the early part of this transient flow period, the productivity of the fractured well is better than that of the unfractured well (the drawdown is smaller for the same rate). After the BDF the differences between the pressure and derivative responses and the productivities of the fractured and unfractured wells become insignificant.

Figure II- 14 shows pseudopressure and derivative responses for a horizontal well with four transverse hydraulic fractures. The flow regimes for this case are the same as those for a horizontal well with two transverse hydraulic fractures. 


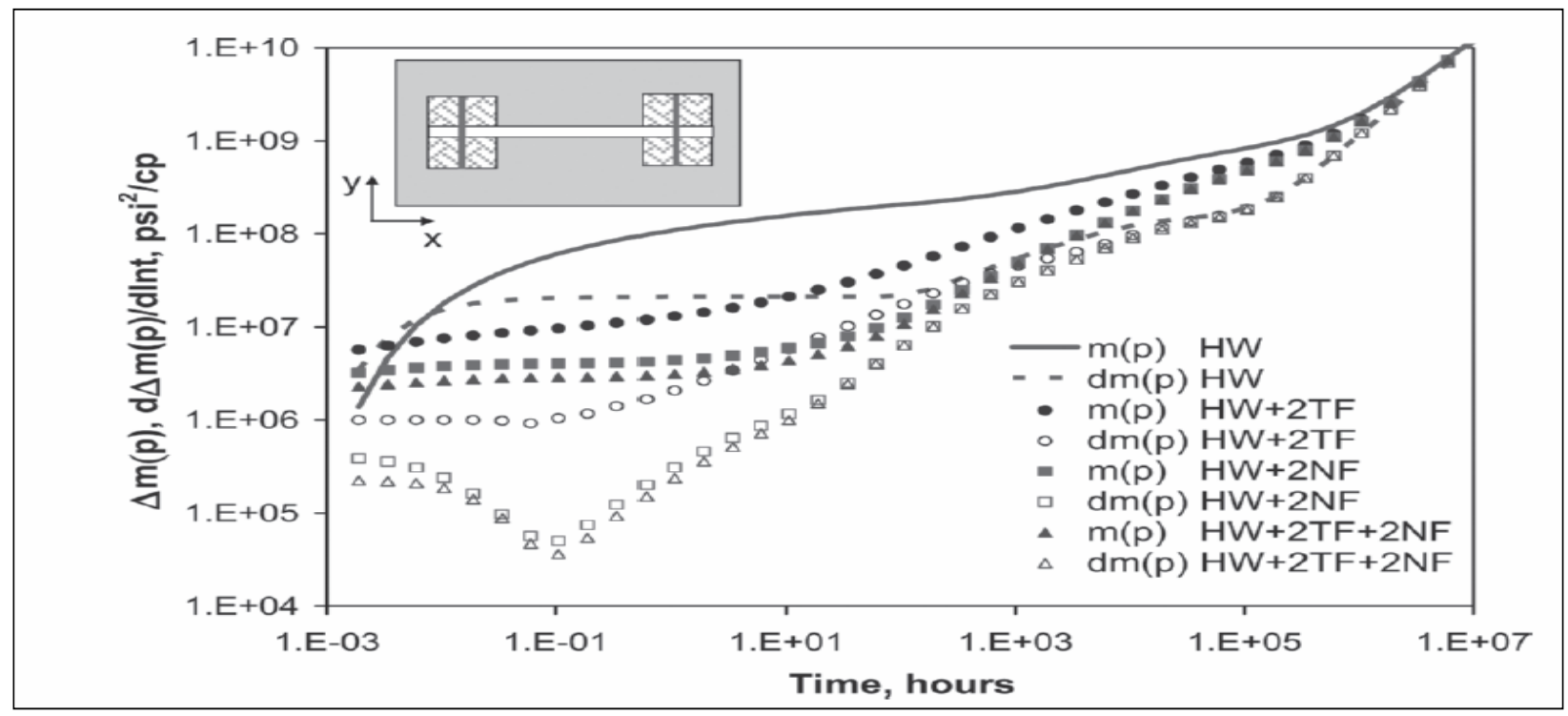

Figure II-13 Pseudopressure and derivative responses for a horizontal well with two transverse hydraulic fractures (Medeiros et al, 2008).

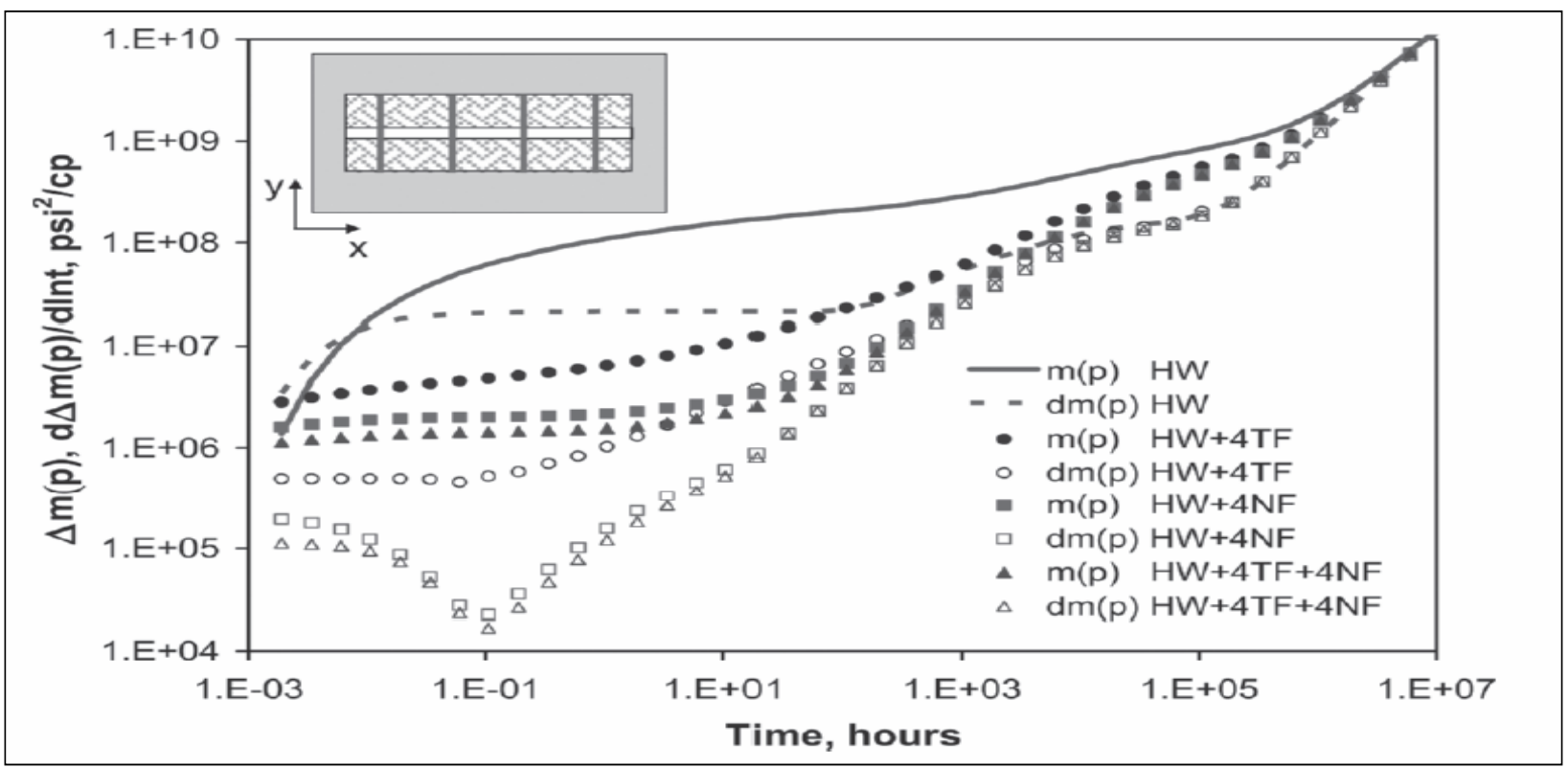

Figure II-14 Pseudopressure and derivative responses for a horizontal well with four transverse hydraulic fractures (Medeiros et al, 2008). 


\subsection{Application of Well Configurations (Multi - lateral wells):}

In the past, all drilled wells were vertical, and the workers in the industry did not know much about the geology until the horizons were drilled and logged or cored. For this reason, the industry was often content to have one commercially successful well in 10 tries, but after the horizontal well drilling technology has been invented and the current seismic interpretation changed what can be known about the geology before a well is drilled. These days, only one development well in seven is a dry hole. With the current technology the wells can be steered by using the previously interpreted surface seismic data, and seismic and log data acquired while drilling (Hill et al, 2008).

The well configurations - vertical, vertical with fractures, single horizontal wells, or multilateral, multibranched, or multilevel wells - must be accommodated to the geologic setting, the size of the intended drainage volume, and many other reservoir characteristics, including stress and permeability anisotropy and the location of geological discontinuities such as faults. Views such as these touch practically all features of the life of the well, including the productivity index, as well as water and gas management in the case of an oil well (Hill et al, 2008).

The well architecture design, well paths, and completion plans are dependent on the reservoir configuration and types of produced fluids. Reservoir heterogeneities and anisotropies also play a major role. The well drainage volume is a determining factor to select the best method to complete the reservoir (Hill et al, 2008). Yildiz (2005) presented 
experimental and theoretical investigations of multilateral/duallateral horizontal well performance in areally anisotropic reservoirs. He categorized the advantages of multilaterals wells as:

- More contact area with reservoir.

- Accelerated production.

- Better well control compared to a long single lateral.

- Less drill sites.

- Less drill footage.

- Minimization of wellbore pressure losses.

- Better reservoir coverage and definition.

- Improved control over flooding patterns.

There are many common reservoir geometries studied and the well architecture for each is described. In this study the focus is on the naturally fractured reservoirs.

\subsubsection{Well Configurations in Gas Shale Formations:}

Single horizontal well provides significant advantages in naturally fractured reservoirs, if they are drilled perpendicular to the fracture planes, but natural fractures might create rapid water or gas breakthrough into the well. To foreclose such problems, many natural fractured reservoirs should be operated at a low pressure drawdown as economically as 
possible. One solution is to drill opposing dual lateral wells, a very common procedure in areas such as the Austin chalk in Texas (Hill et al, 2008).

Naturally fractured shale formations (Barnett Shale) was completed by vertical wells till 2002, from this year horizontal wells have been drilled. When these horizontal wells stimulated, they will be able to drain several parallel sections of reservoir, thus expanding the overall drainage area (Montgomery et al, 2005).

Natural opening - type fractures in the Barnett shale are mostly narrow, sealed with calcite, these narrow fractures are all sealed and cannot conduce to reservoir storage or increase permeability unless they will be reactivated by hydraulic fractures.. Gale et al (2007) consider the Austin Chalk to be a good analog for the Barnett shale with respect to natural fracture patterns. Horizontal wells drilled in the Austin Chalk exploit these open fracture clusters. By analogy, horizontal wells drilled perpendicular to natural fractures in the Barnett shale might intersect an open fracture cluster. If the fractures are contained within the shale, then this could be useful in enhancing permeability (Gale et al, 2007).

\subsubsection{Multilateral well systems:}

There are several multilateral well systems in the literature. By drilling many drain holes from a main horizontal or vertical well, the producers can exploit resources which used to be inaccessible and multilateral well systems can drain these resources efficiently. 


\subsubsection{Economides, M.J., Retnanto, A. and Frick, T.P.:}

Multilateral wells are classified to several configurations by Economides et al (1996) as:

- Multi- branched well Figure (II-15) a.

- Fork well Figure (II-15) b.

- Several laterals branching into one horizontal "mother hole" Figure (II-15) c.

- Several laterals branching into one vertical "mother hole" Figure (II-15) d.

- Dual opposing laterals Figure (II-15) e.

- Stacked laterals Figure (II-15) f.

Figure II-16 shows additional well configurations presented by Economides et al, (1996).

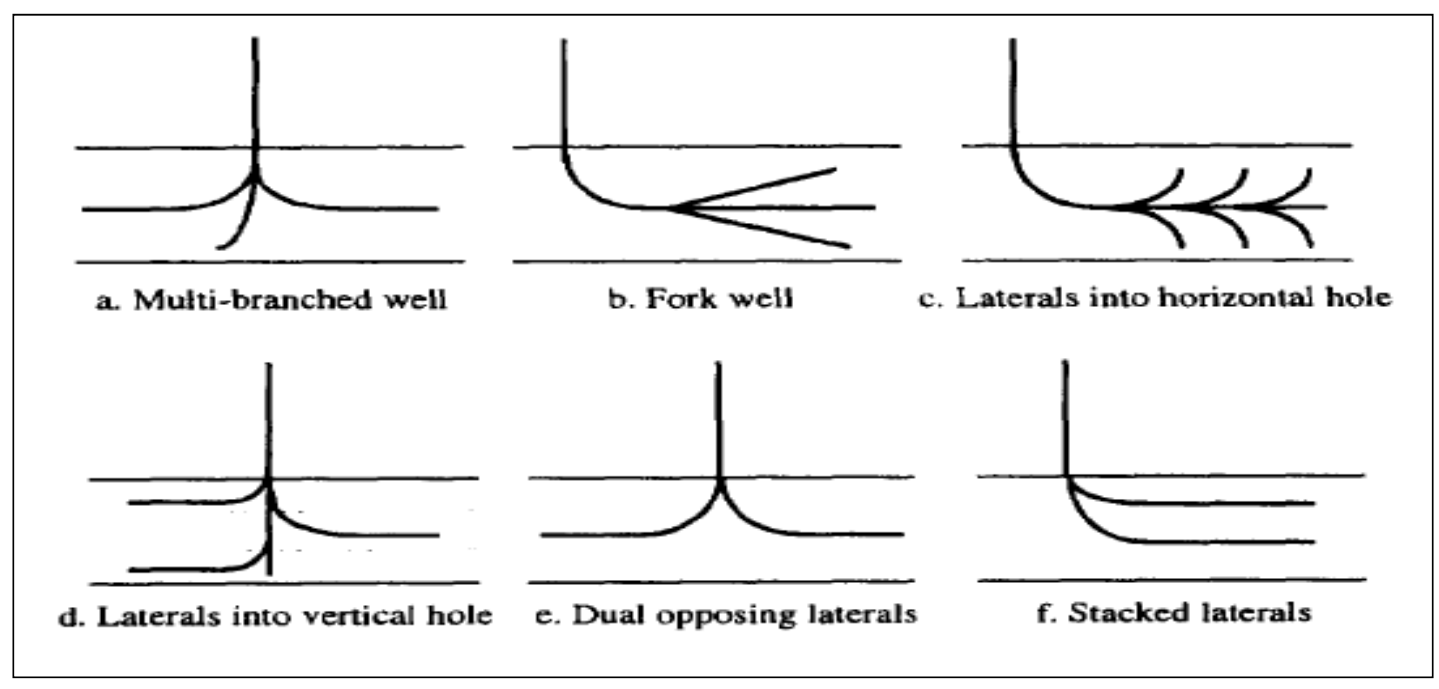

Figure II-15 Multilateral well designs (Economides et al, 1996). 


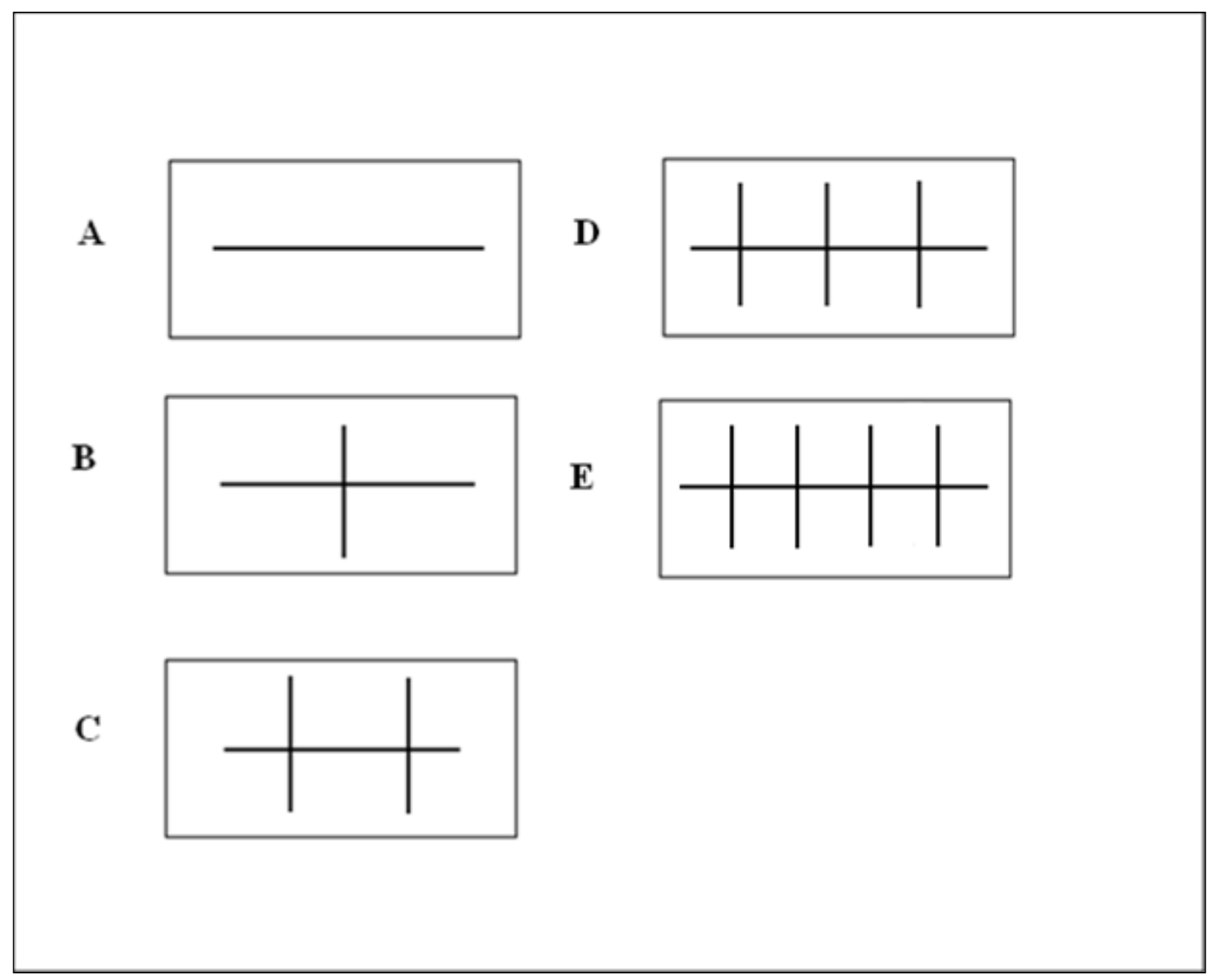

Figure II-16 Multilateral well designs (Economides et al, 1996). 


\subsubsection{Maricic, N., Mohaghegh, S.D. and Artun, E.:}

Maricic et al (2005) presented a parametric study on the benefits of drilling horizontal and multilateral wells in coal bed methane reservoirs. Their study encompasses several well configurations system as shown in Figure II-17.

Both coal bed methane and shale reservoirs are naturally fractured reservoirs, so that the well configurations used in coal bed methane might be suitable for shale reservoirs.

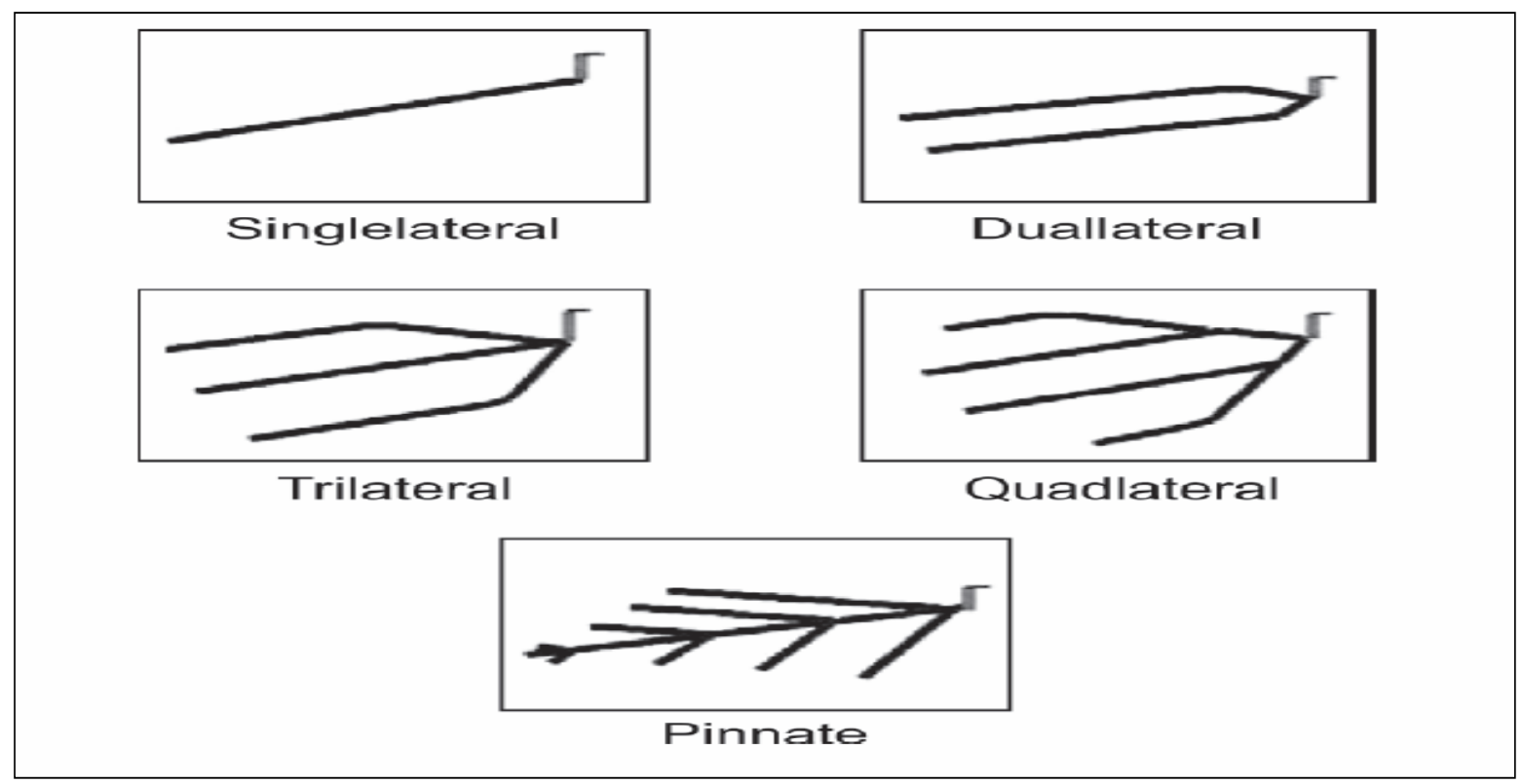

Figure II-17 Multilateral well designs (Maricic et al, 2005). 
2.5.2.3 Powell, A., Bustos, O., Kordziel, W., Olsen, T., Sobernheim, D. and Vizurraga, T.:

Powell et al (2007) presented a paper under the title of "Fiber - Laden Fracturing Fluid Improves Production in the Bakken Shale Multilateral Play”. In this paper they discussed the different well configurations used in the Bakken shale in Montana and North Dakota, as shown in Figure II-18, Figure II-19 and Figure II-20.

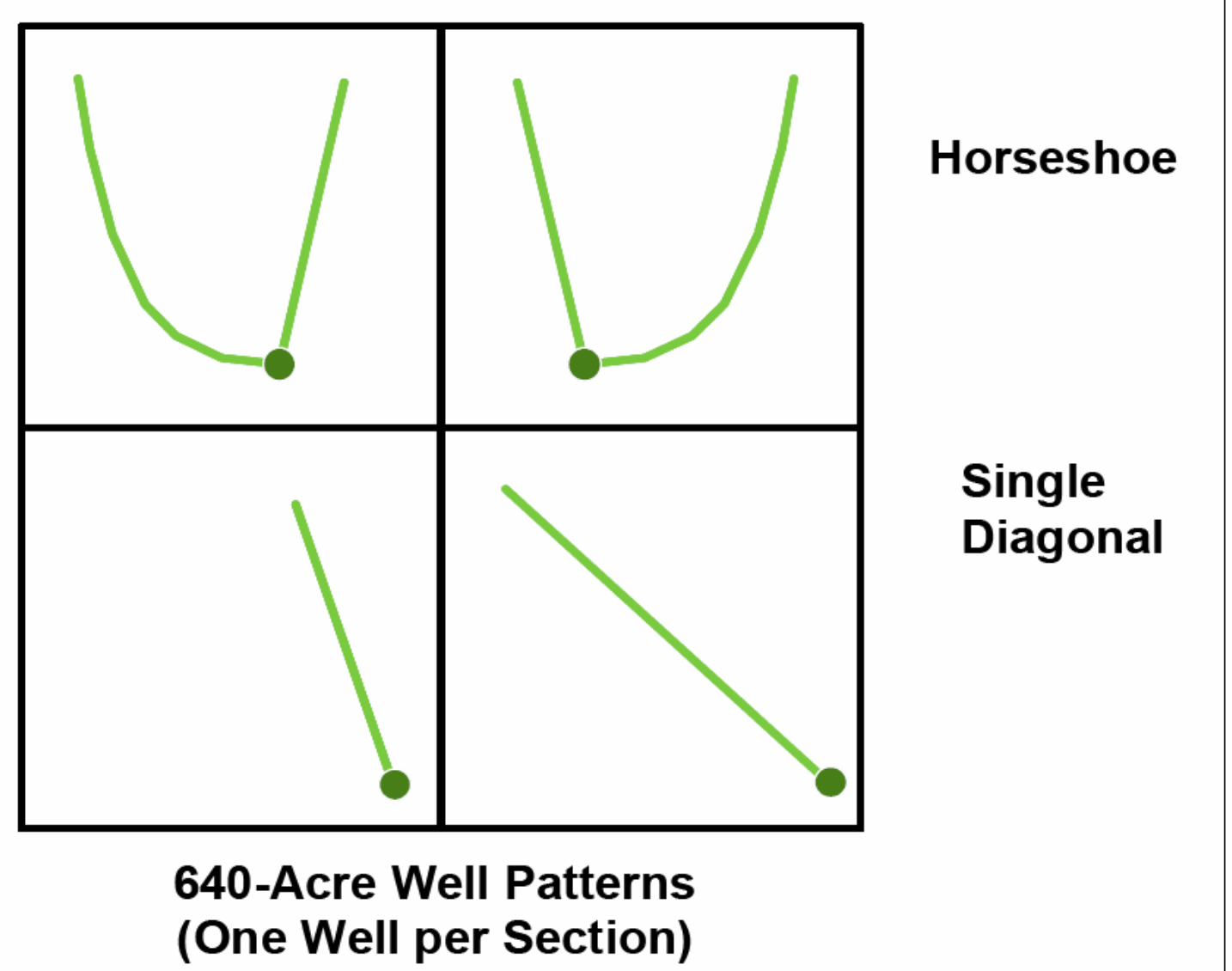

Figure II-18 Multilateral well designs in Montana and North Dakota (Powell et al, 2007). 


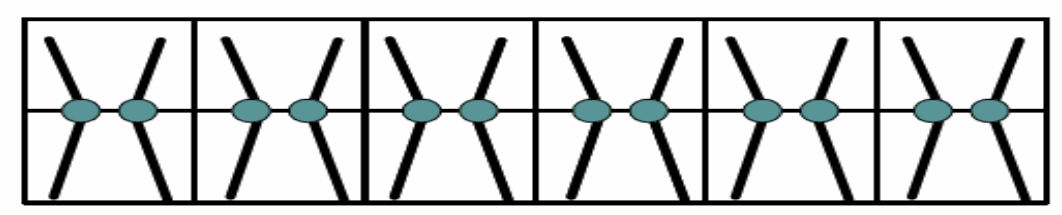

Bow-Tie

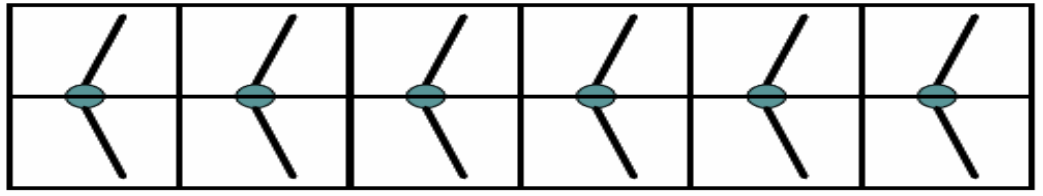

Chevron

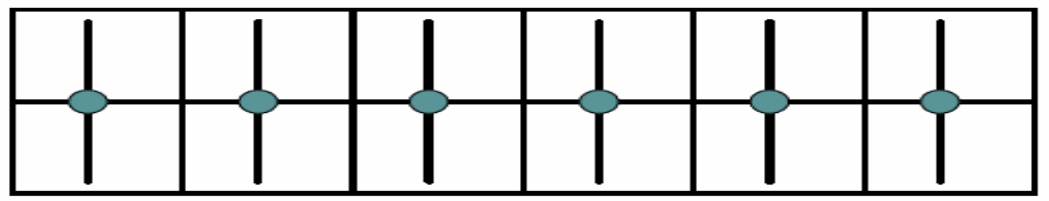

Straight

Figure II-19 Dual laterals well designs in Montana (Powell et al, 2007).

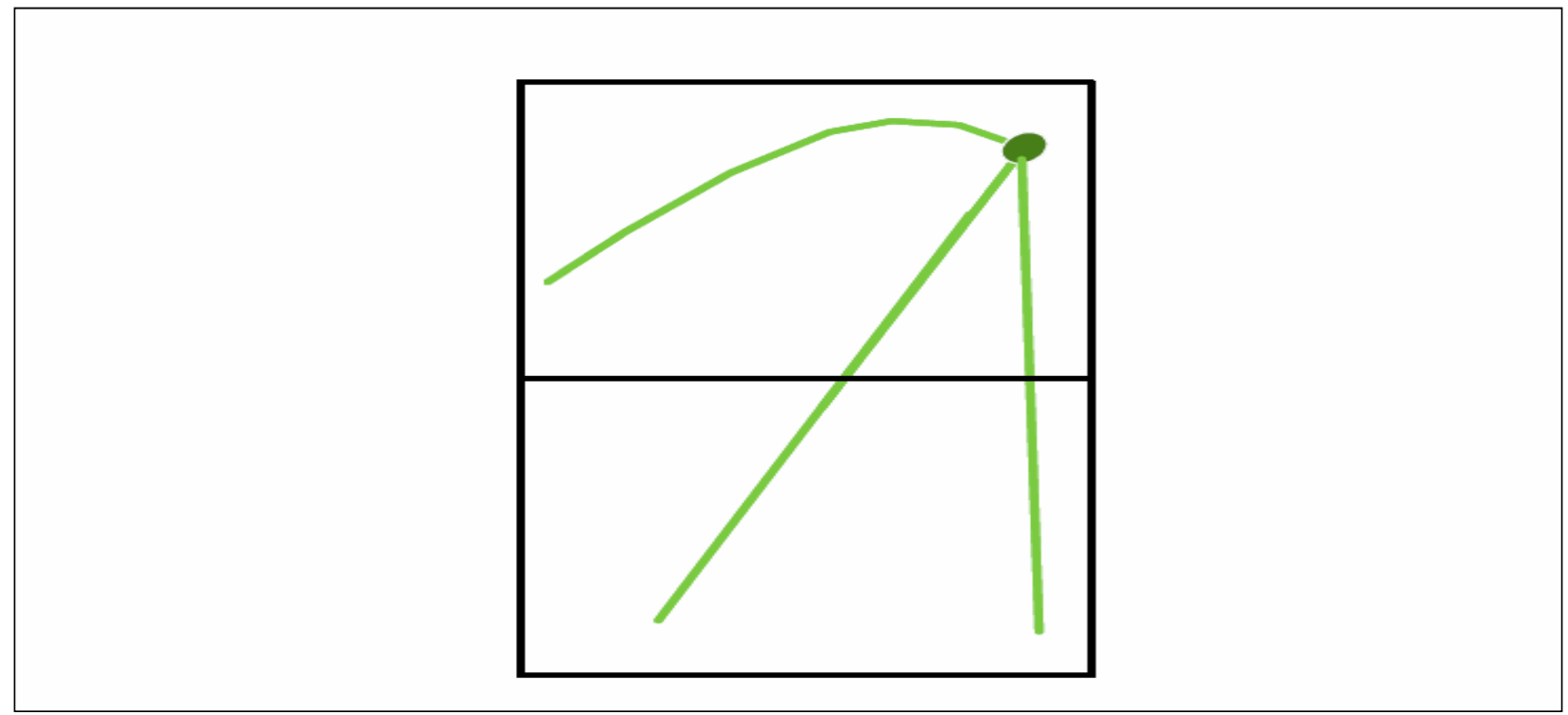

Figure II-20 Tri- laterals well design in North Dakota (Powell et al, 2007). 


\subsection{Gas Shale Formation stimulation:}

\subsubsection{Gas Shale Stimulation:}

The selection of the feasible gas shale is dependent on many parameters, such as kerogen type, total organic content (TOC), thermal maturity (measured by vitrinite reflectance), gas content, mineral content and other traditional petrophysical properties (Matthews, 2008). Mineral content and natural fractures, both open and sealed are the major factors on the success of the hydraulic fracturing process. Shale rich with quartz has found to be easy to fracture (Waters, 2009).

The intention behind the stimulation of gas shale formations is to adjoin as much reservoir rock as possible with a conductive flow path to the wellbore and keep the hydraulic fractures within the shale. To achieve this objective, a simultaneous fracture technique (simo - frac) of two offset wells drilled parallel to one another with well spacing of the order of 500 to 700 feet is practiced in Barnett Shale (Mutalik and Gibson, 2008), Figure II-21 shows three horizontal wells drilled parallel to each other. This method results in a significant degree of communication between offset wellbores thousands of feet away (Matthews, 2008).

Historically, slick water as a method of stimulation was introduced to the Barnett Shale in 1996, and in 2002 horizontal well with multi stage slick water fracturing was applied in 
Barnett Shale. The number of hydraulic fracturing stages reached up to ten stages during 2007 (Matthews, 2008).

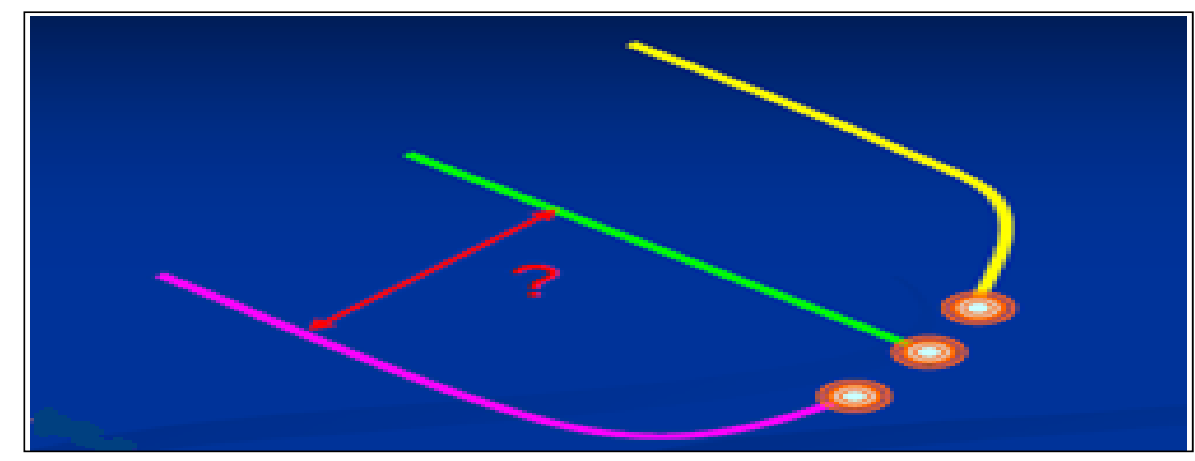

Figure II-21 Three horizontal wells drilled parallel to each other (Matthews, 2008).

\subsubsection{Multilateral well Stimulation:}

In many cases the purpose of using multilateral wells instead of vertical wells is to increase the reservoir deliverability without the applications of well stimulation. However, it is unavoidable that some multilateral wells can be improved by well stimulation; in fact, hydraulic fracturing may be necessary to create an economic well in low - permeability reservoirs such as gas shales (Hill et al, 2008).

Stimulation of a single lateral is the same as a single wellbore in a conventional completion, except the need for special efforts to place the treating fluids in the desired lateral. In the case of hydraulic fracturing, the consideration of interaction of one stimulated lateral with others should be considered. Since most laterals in a multilateral well are long, nearly horizontal wellbores, stimulation procedures for long horizontal wells are required in multilaterals (Hill et al, 2008). 
The hydraulic fracturing of a single lateral of multilateral wells is possible and has been done on a great number of cases (Hill et al, 2008). In some of these cases, the dual lateral wells are treated simultaneously, so that fractures are created in more than one lateral during one large treatment. The common practice in multilateral well stimulation is to place multiple hydraulic fractures along the laterals (Hill et al, 2008).

There are two obvious limiting cases for horizontal lateral fracturing:

- Longitudinal fractures, where the well is drilled perpendicular to the minimum horizontal stress direction.

- Transverse fractures, where the well is drilled parallel to the minimum horizontal stress. Figure II-22 shows transverse fractures intersecting horizontal well.

In this study the main focus is to investigate the effect of different well configurations on the productivity index, and these different well configurations will be stimulated by eight stages transverse hydraulic fractures which have been practiced in the Barnett Shale during 2006 in a horizontal well with a lateral of $4063 \mathrm{ft}$ (Matthews, 2008).

As mentioned previously the hydraulic fracturing of a single lateral of multilateral wells is possible and has been done on a great number of cases (Hill et al, 2008). Thus, instead of setting eight stages on one lateral, probably sixteen stages can be set on dual - laterals (eight stages per lateral) resulting in the same total length of a single lateral. 


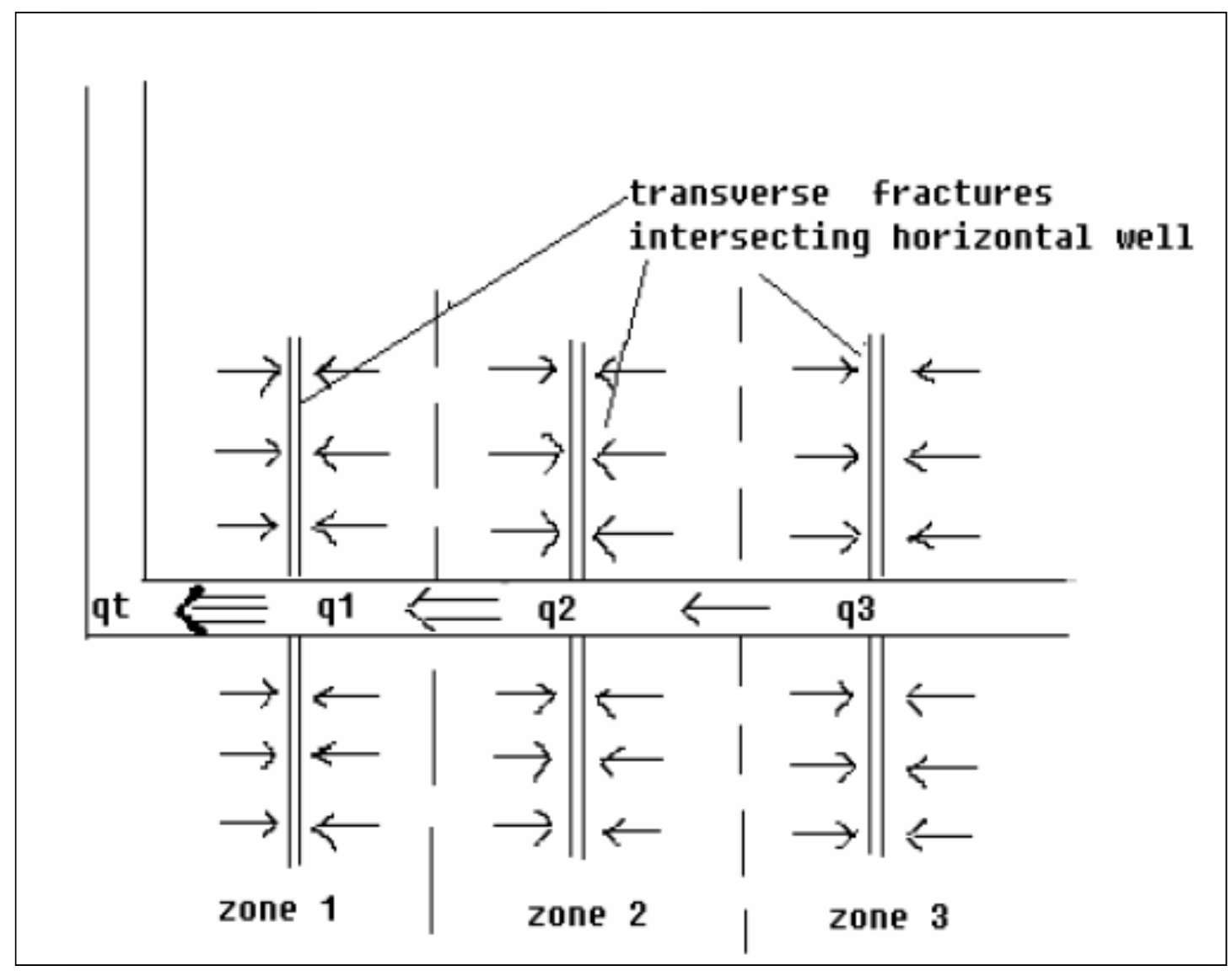

Figure II-22 Transverse hydraulic fractures intersecting horizontal well (Wei and Economides, 2005). 


\section{CHAPTER III}

\section{METHODOLOGY}

The objective of this study is to determine the effect of different well configurations on the productivity index of gas wells drilled in shale formation. Well configurations were modeled by using a reservoirs simulation program. Various flow regimes for these configurations were studied to determine their effect on the productivity index.

In this study, a reservoir simulation was utilized to determine the behavior of gas shale formation completed with different well configurations. The results were used to determine the productivity index of each well design. Total production from the different well configurations was used to confirm the best well configuration design. The results were compared for each design with respect to base case horizontal well completed with eight transverse multi - stage hydraulic fractures.

\subsection{Reservoir Simulation Design:}

Commercially available software (Eclipse, Schlumberger) was used in this research to simulate gas shale reservoir. Reservoir simulators have been the benchmark for commercial reservoir studies for over 25 years because of their comprehensive quality, parallel scalability, utility computing, and unmatched platform coverage. Complex well 
models can be designed by Eclipse and also different types of completion such as hydraulic fractures. There are four different options in Eclipse software (Schlumberger):

- Black - oil.

- Compositional.

- Thermal.

- Streamline.

- Add - On Options.

In this study, the compositional option was used, because it is ideally studied for natural fracture reservoir modeling. The version that used in this study is Eclipse 2007.2. Coal Bed Methane template was used with shale properties to represent shale gas formation behavior similar to the coal bed methane. Both coal bed methane and shale represent dual - porosity model. The basic dual - porosity model parameters that were included in the model are:

- Shale matrix porosity and permeability.

- Natural fracture porosity and permeability.

- Langmuir Isotherm input:

- Langmuir Pressure constant.

○ Langmuir Concentration constant.

- Sigma $(\sigma)$, shale matrix shape factor (Equation II- 9) 
The reservoir simulation used to represent gas shale formation had two phases (Gas \& Water). The reservoir properties were collected from the literature and these properties represent Barnett Shale, which has been used as a model for most of the prospective shale plays in the entire United States of America, because of its successful production history.

The reservoir simulation in this study has grid dimensions with maximum and minimum cell size of 100 and 50 feet, respectively in $\mathrm{x}, \mathrm{y}$ and $\mathrm{z}$ directions. These grid sizes were selected after several tries which resulted with more accurate output and faster running time. Local grid refinement is used automatically by the software program to describe properties of the well laterals and the induced hydraulic fractures.

The model was designed to produce with unlimited flow rate (open to flow), and the bottomhole pressure limit is 500 psia.

\subsection{Reservoir Data:}

The reservoir data used to build the reservoir simulation were collected from published documents about the Barnett Shale (Lewis and Hughes, 2008). The hydraulic fracture properties were selected from Medeiros et al, (2008).

The representative reservoir data were used to run the simulator for different case scenarios; representing different well configurations. The base case has a single horizontal well with a length of $5000 \mathrm{ft}$, completed with eight stage hydraulic fractures in squire drainage area of 3306 acres $(12,000 \mathrm{ft} \times 12,000 \mathrm{ft})$. 
The initial gas in place is $250 \mathrm{BCF}$. All runs are conducted for a 30 year period. Table III-

1 shows the representative reservoir data used to run the simulator for all cases:

Table III-1 Representative reservoir data that are used to run the reservoir simulation.

\begin{tabular}{|l|l|}
\hline Simulation time (years) & 30 \\
\hline Formation thickness $(\mathrm{ft})$ & 100 \\
\hline Well drainage area (acres) & 3306 \\
\hline True vertical depth $(\mathrm{ft})$ & 7500 \\
\hline Natural fracture porosity (fraction) & 0.005 \\
\hline Natural fracture permeability (md) & 0.0025 \\
\hline Matrix porosity (fraction) & 0.06 \\
\hline Matrix permeability (md) & 0.0005 \\
\hline Shale matrix shape factor, Sigma $(\sigma),\left(1 / f t^{2}\right)$ & 0.0073500029 \\
\hline Shale compressibility $(1 / p s i)$ & 0.000001 \\
\hline Rock density $\left(l b / f t^{3}\right)$ & 89.52 \\
\hline Reservoir pressure (psia) & 4000 \\
\hline Water saturation (fraction) & 0.05 \\
\hline Total lateral length $(\mathrm{ft})$ & 5000 \\
\hline Well bore radius $\left(r_{w}\right),(\mathrm{ft})$ & 0.33 \\
\hline Flow rate $($ MSCF/D) & Unlimited (open to flow) \\
\hline Bottomhole flowing pressure (psia) & 500 \\
\hline Reservoir temperature (degrees Fahrenheit) & 180 \\
\hline Langmuir pressure constant (psia) & 635 \\
\hline Langmuir concentration constant (SCF/US ton) & 89 \\
\hline
\end{tabular}


The hydraulic fractures properties used in this study are shown in Table III-2:

Table III-2 Hydraulic fracture properties that are used to run the reservoir simulation.

\begin{tabular}{|l|l|}
\hline Fracture half - length, $\left(x_{f}\right),(\mathrm{ft})$ & 200 \\
\hline Fracture width $,\left(w_{f}\right),(\mathrm{in})$ & 0.24 \\
\hline Hydraulic fracture permeability $(\mathrm{md})$ & 1000 \\
\hline Fracture porosity $\left(\varnothing_{f}\right),($ fraction$)$ & 0.1 \\
\hline
\end{tabular}




\subsection{Well configurations:}

The strategy used to study the effect of different well configurations on the productivity index of gas well producing from shale formation is to compare the productivity index of base case $(\mathrm{BC})$ with other cases.

All cases have the same total lateral length of $5000 \mathrm{ft}$, and the number of hydraulic fracture for all cases are eight hydraulic fractures distributed throughout the laterals. These eight hydraulic fractures have the same properties, (Table III-2). The other representative reservoir properties were kept constant in all runs. Table III-3 lists the well configurations used in this study. These well configurations represent the most common well configurations that have been used in the shale formation such as Bakken shale in Montana and North Dakota.

Table III-3 Well configurations or designs used in this study.

\begin{tabular}{|l|l|}
\hline Number of case & Well configurations or designs \\
\hline 1 & Single horizontal well (Base Case, BC ) \\
\hline 2 & Two parallel horizontal Well (TPHW) \\
\hline 3 & Dual - lateral Well (DLW) \\
\hline 4 & V - well (VW) \\
\hline 5 & Tri - lateral well (TLW) \\
\hline 6 & Chicken - foot well (CFW) \\
\hline 7 & Web - well (WW) \\
\hline
\end{tabular}




\subsubsection{Base Case (BC):}

The base case used in this study is a single horizontal well parallel to the x-axis, Figure III-1, placed in the middle of the shale layer. The eight induced multi - stages hydraulic fractures are generated parallel to the y-axis and have a spacing of $600 \mathrm{ft}$.

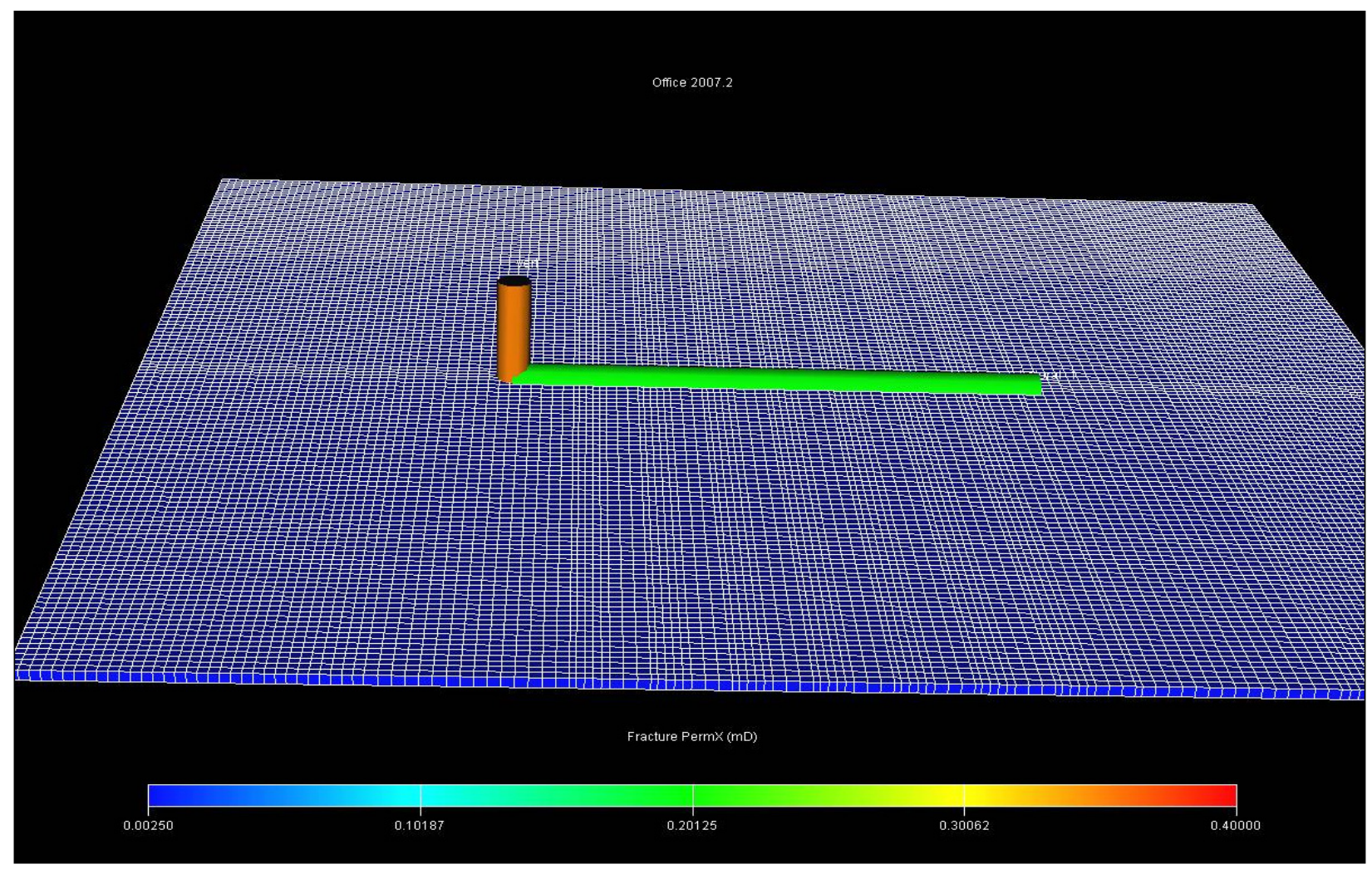

Figure III-1 Single horizontal well representation. 


\subsubsection{Two Parallel Horizontal Wells (TPHW):}

The two parallel horizontal wells are placed in the middle of the shale layer parallel to the $\mathrm{x}$-axis, Figure III-2. The total length for the two wells is $5000 \mathrm{ft}$, with $2500 \mathrm{ft}$ for each well. There are four multi - stage transverse fractures in each lateral parallel to the y-axis with $600 \mathrm{ft}$ fracture spacing.

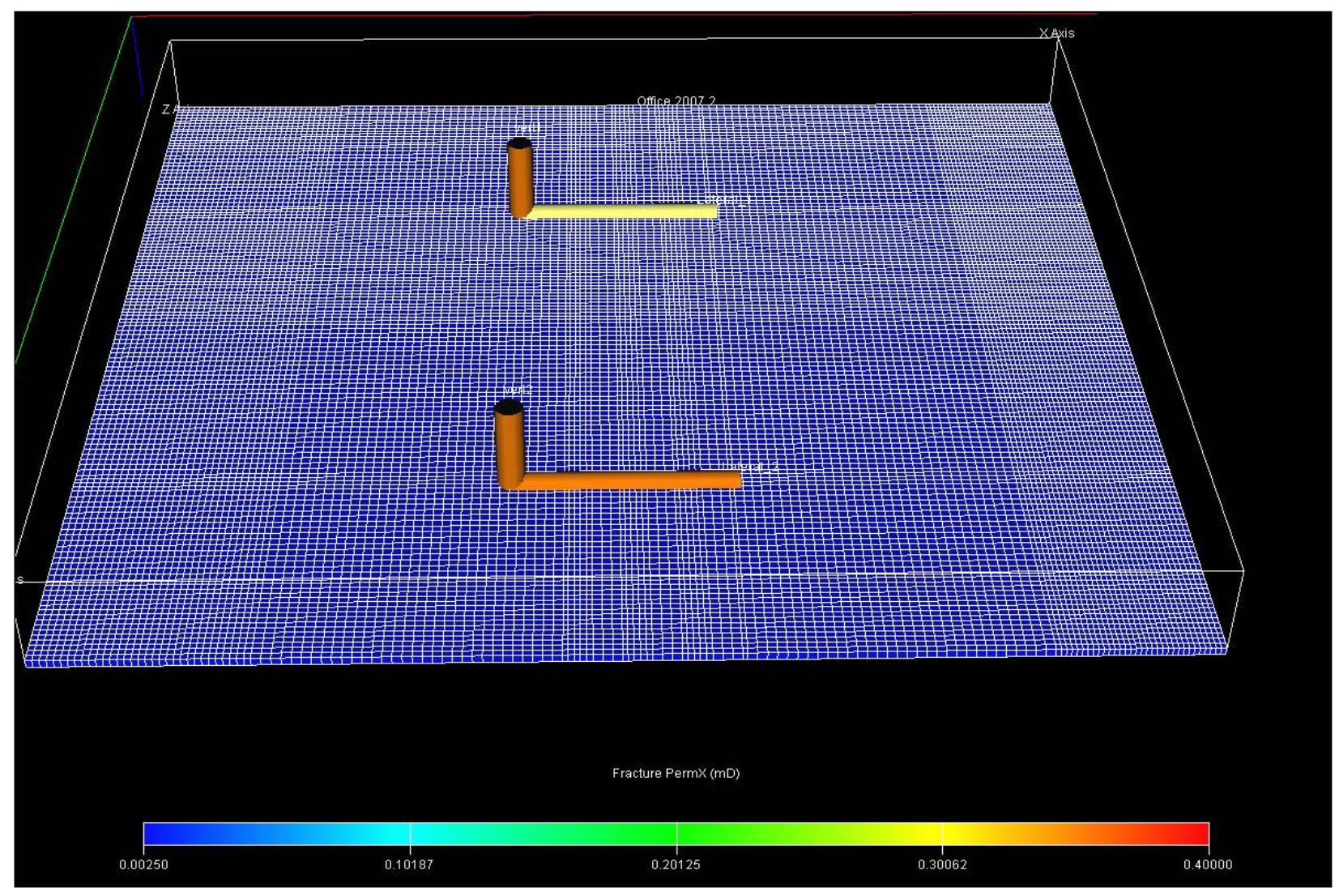

Figure III-2 Two parallel horizontal wells representation. 


\subsubsection{Dual - lateral Well Case (DLW):}

The dual - lateral well is drilled from a vertical well located in the middle of the drainage area, Figure III-3. The total length for the two laterals is $5000 \mathrm{ft}$ parallel to the $\mathrm{x}$-axis, with $2500 \mathrm{ft}$ for each lateral. The angle between the two laterals is $180^{\circ}$ (Dual opposing laterals). There are four multi - stage transverse fractures in each lateral parallel to the $y-$ axis with $600 \mathrm{ft}$ fracture spacing.

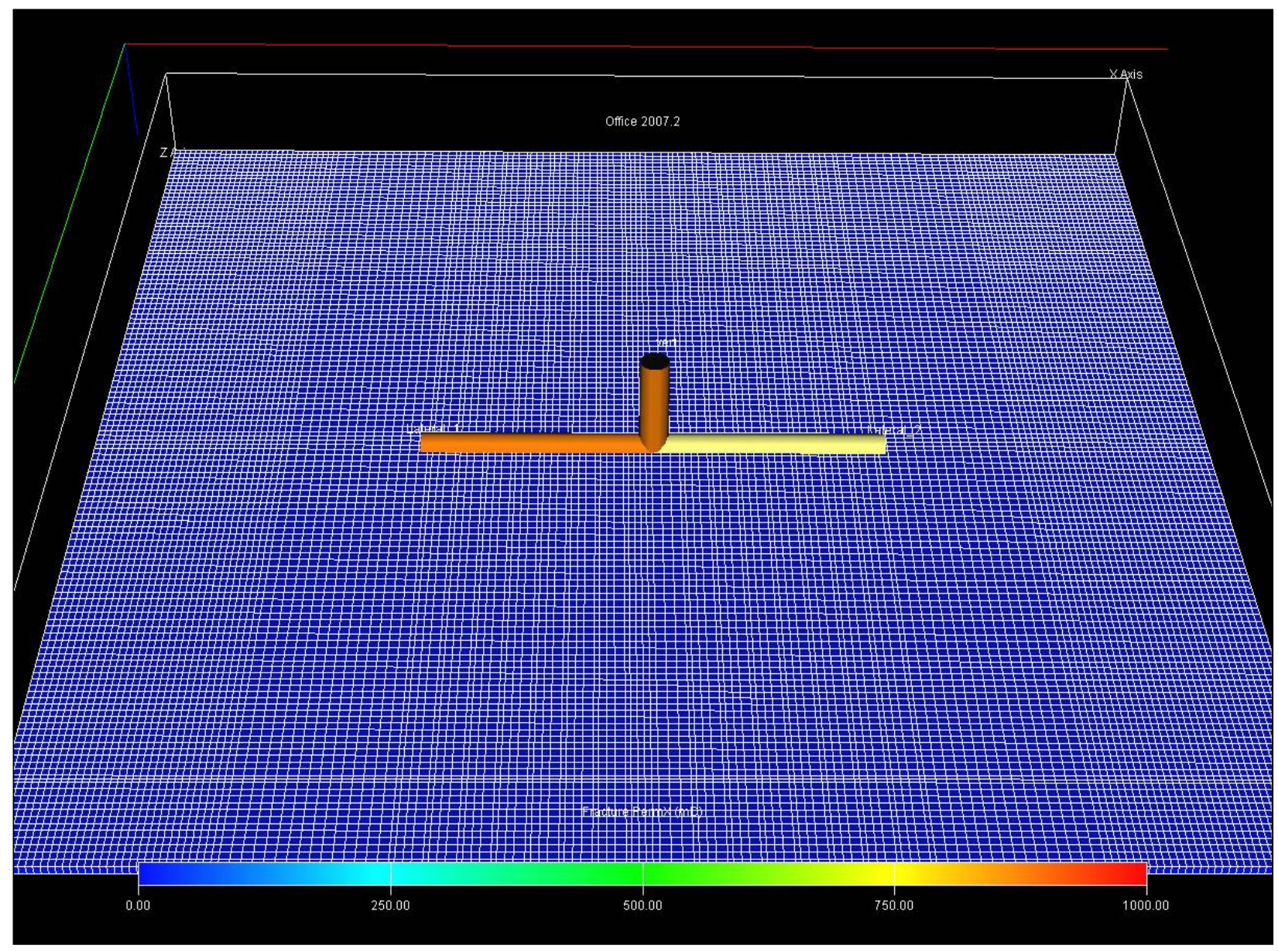

Figure III-3 Dual - lateral well representation. 


\subsubsection{V - Well Case (VW):}

The V - well configuration model could be considered as dual - lateral well, but the angle between the two laterals is $120^{\circ}$ instead of $180^{\circ}$. This results in less spacing distance between the two laterals. The main objective of selecting this well design in this study is to investigate the effect of lateral spacing on the productivity index. This well design has been used in Montana (Powell et al, 2007).

The total lateral length is $5000 \mathrm{ft}$ with $2500 \mathrm{ft}$ for each lateral along the $\mathrm{x}$-axis. Figure III-4 shows the V - well configuration used in this study. There are four multi - stage transverse fractures in each lateral parallel to the y-axis with $600 \mathrm{ft}$ fracture spacing.

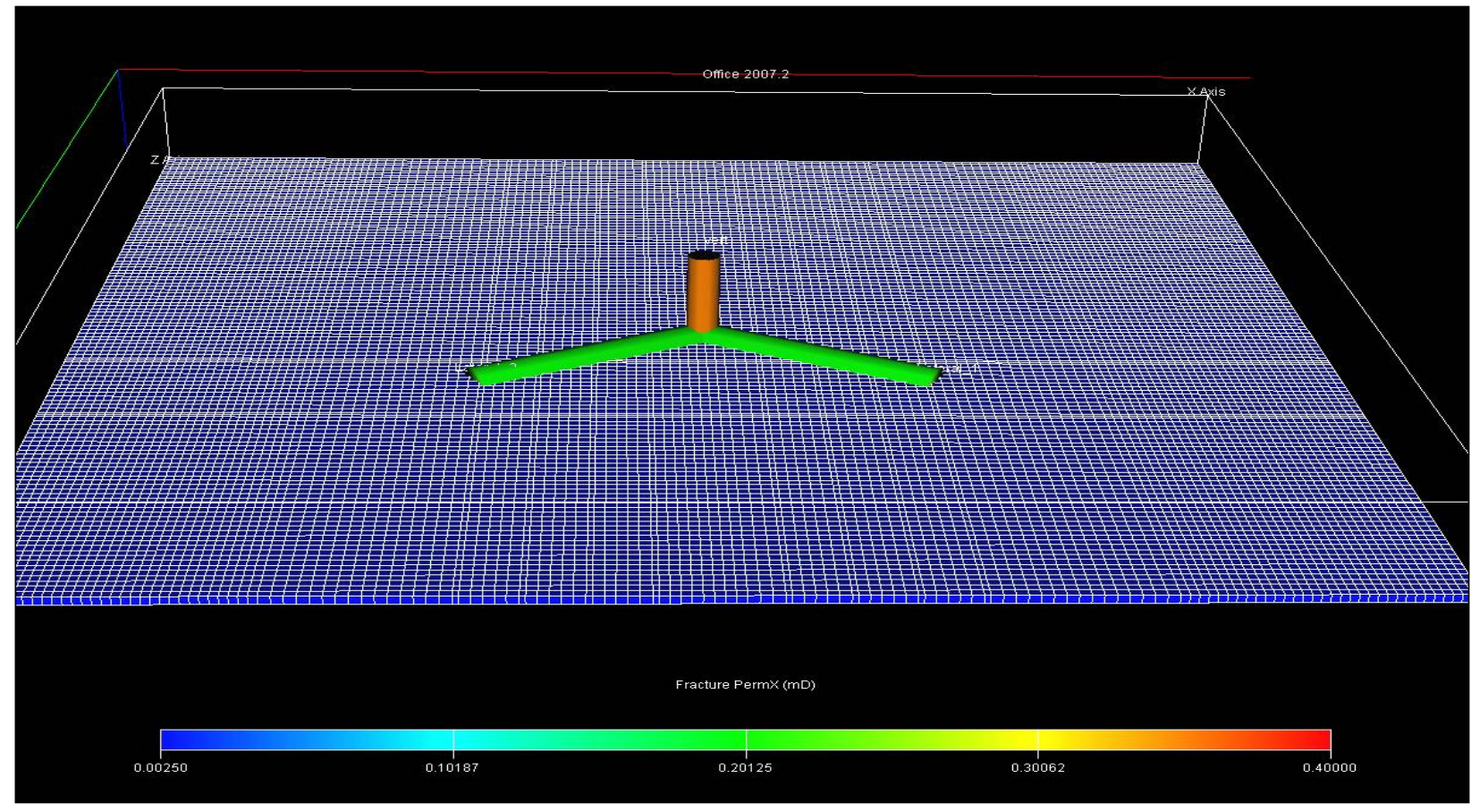

Figure III-4 V - well representation. 


\subsubsection{Tri - lateral Well Case (TLW):}

The tri - lateral well configuration is designed by drilling three laterals from a vertical well located in the center of the drainage area, Figure III-5. Each lateral has a length of $1667 \mathrm{ft}$ so that the total lateral length is approximately $5000 \mathrm{ft}$. The first lateral is placed parallel to the $y$-axis and the other two laterals are placed $120^{\circ}$ to the first lateral. There are four multi - stage transverse fractures in the first lateral with $400 \mathrm{ft}$ fracture spacing and two stage transverse fractures for each of the two leg laterals with $800 \mathrm{ft}$ fracture spacing. All transverse fractures are generated parallel to the x-axis.

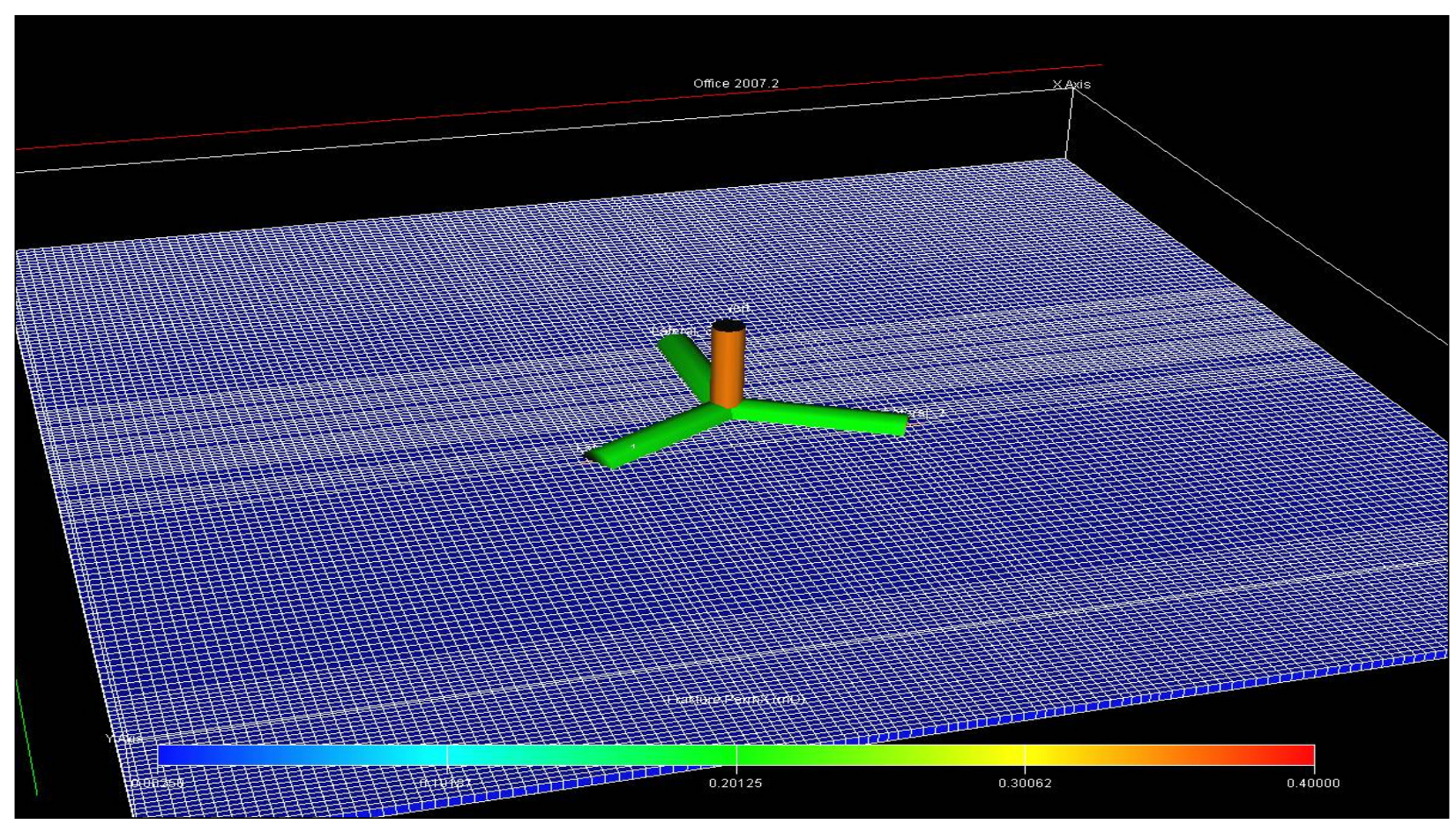

Figure III-5 Tri - lateral well representation. 


\subsubsection{Chicken - Foot Well Case (CFW):}

The chicken - foot well configuration is driven from the $\mathrm{V}$ - well configuration by drilling one more lateral between the already drilled two laterals, Figure III-6. Thus, the spacing between the three laterals is decreased by $50 \%$ compared to the $\mathrm{V}$ - well configuration model. The length for each lateral is the same as the tri - lateral well model, but the angle between the laterals is $60^{\circ}$ instead of $120^{\circ}$. There are two transverse hydraulic fracture stages with $700 \mathrm{ft}$ fracture spacing in the middle lateral which is placed parallel to the $\mathrm{x}$-axis. The other two laterals have three stages of transverse hydraulic fractures with $500 \mathrm{ft}$ fracture spacing. The hydraulic fractures are generated for each lateral parallel to the y-axis.

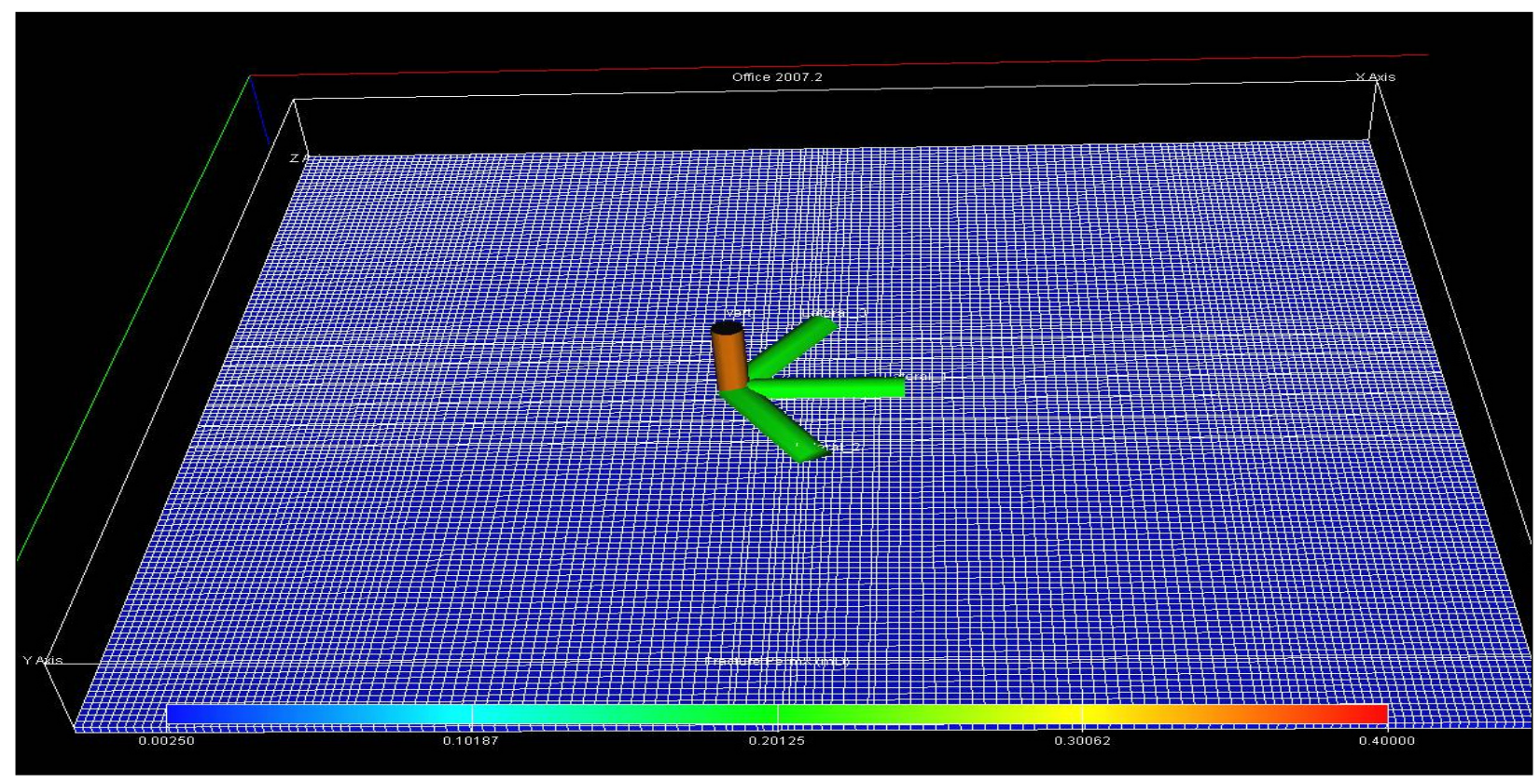

Figure III-6 Chicken - Foot well representation. 


\subsubsection{Web - Well Case (WW):}

There are six laterals in this well configuration with $60^{\circ}$ between each lateral, and the length for each lateral is $833 \mathrm{ft}$ Figure III-7. There are two stages of hydraulic fracture in the two laterals that are parallel to the $\mathrm{y}$ - axis, the fracture spacing is $300 \mathrm{ft}$. The other four laterals have one hydraulic fracture on each lateral, the distance between the vertical well and the hydraulic fracture is $400 \mathrm{ft}$. All fractures are generated along the $\mathrm{x}$-direction for all laterals.

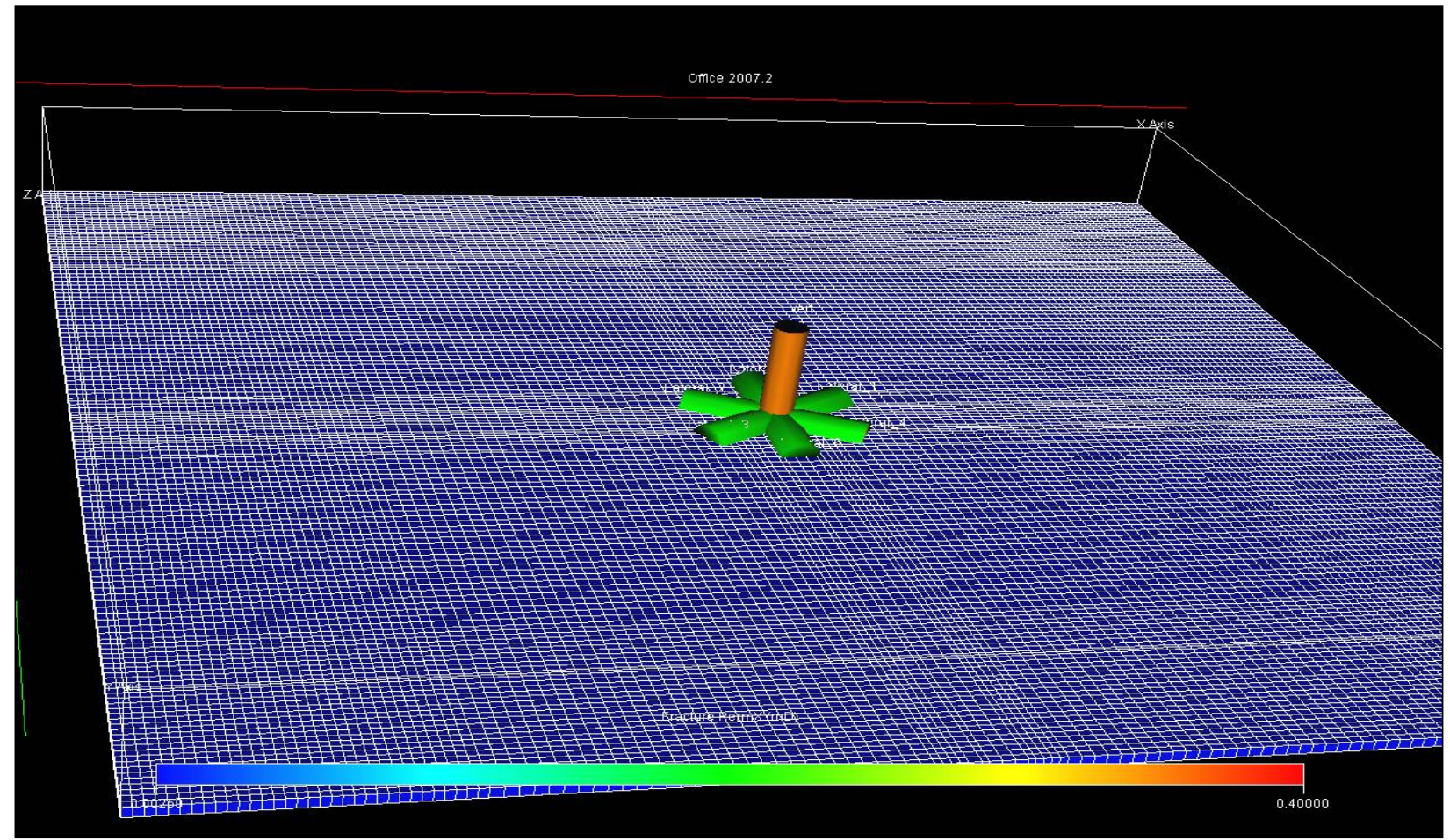

Figure III-7 Web - well representation. 


\subsection{Grid System Selection:}

The grid system was selected after trying different grid sizes. Grid size selection in Coal Bed Methane-Template option of the software used in this study has a local refinement setup; with minimum and maximum cell sizes in $\mathrm{x}, \mathrm{y}$ and $\mathrm{z}$ directions. Table III-4 shows the different grid sizes that were tested in this study.

Table III-4 Minimum and Maximum cell size for three different trials.

\begin{tabular}{|l|l|l|l|}
\hline Trials & First Trial & Second Trial & Third Trial \\
\hline $\begin{array}{l}\text { Minimum Cell Size (ft) } \\
\text { (in x,y and z direction) }\end{array}$ & 25 & 50 & 150 \\
\hline $\begin{array}{l}\text { Maximum Cell Size (ft) } \\
\text { (in x,y and z direction) }\end{array}$ & 50 & 100 & 150 \\
\hline
\end{tabular}

The cell size limitations that are shown in Table III-4 divides the total drainage area into number of blocks in $\mathrm{x}, \mathrm{y}$ and $\mathrm{z}$ directions and these blocks are distributed by a growth factor. The blocks that are closer to the wells and the hydraulic fractures will have smaller sizes than those blocks far from the wells and the hydraulic fractures. This distribution of blocks throughout the entire drainage area is controlled by the growth factor to achieve the required local refinement with best accuracy and also shortest running time. The growth factor that was used in this study has a value of two. 
Figure III-8 and Figure III-9 show the results of bottomhole flowing pressure versus time for the single horizontal well (Base case) and the Tri - lateral well, respectively, for three different cell combinations. All runs were conducted with a constant flow rate of 400 MSCF/D. Based on the results, a minimum of $50 \mathrm{ft}$ and a maximum of $100 \mathrm{ft}$ for the cells size in $\mathrm{x}, \mathrm{y}$ and $\mathrm{z}$ directions were selected for this study based on acceptable accuracy and reasonable running time. A restriction of $500 \mathrm{psi}$ for the bottomhole flowing pressure was used.

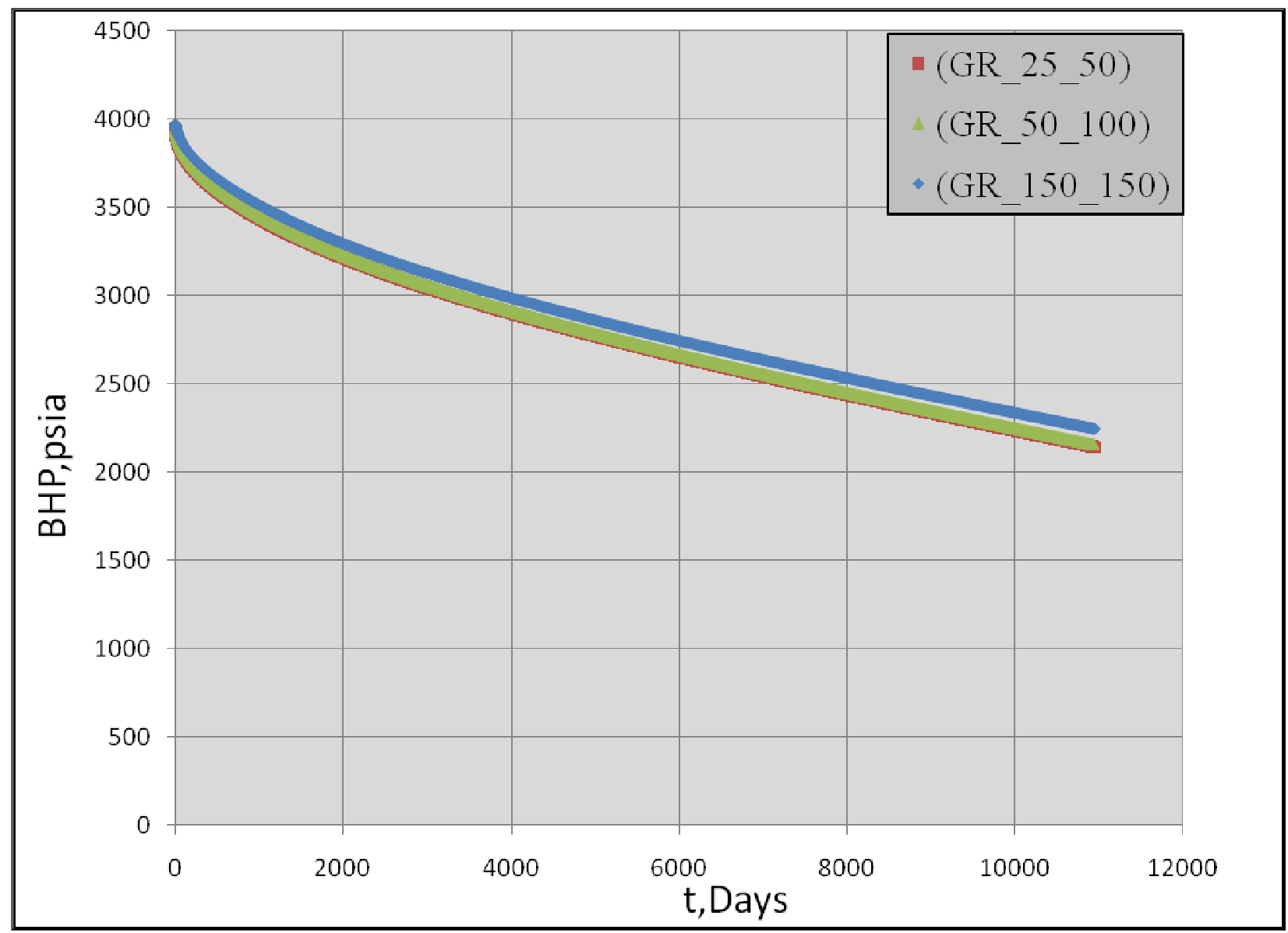

Figure III-8 Bottomhole flowing pressure versus time for a horizontal well with eight fractures treatments $\left(\mathrm{x}_{\mathrm{f}}=200 \mathrm{ft}\right)$ tested by three different cell size limitations. 


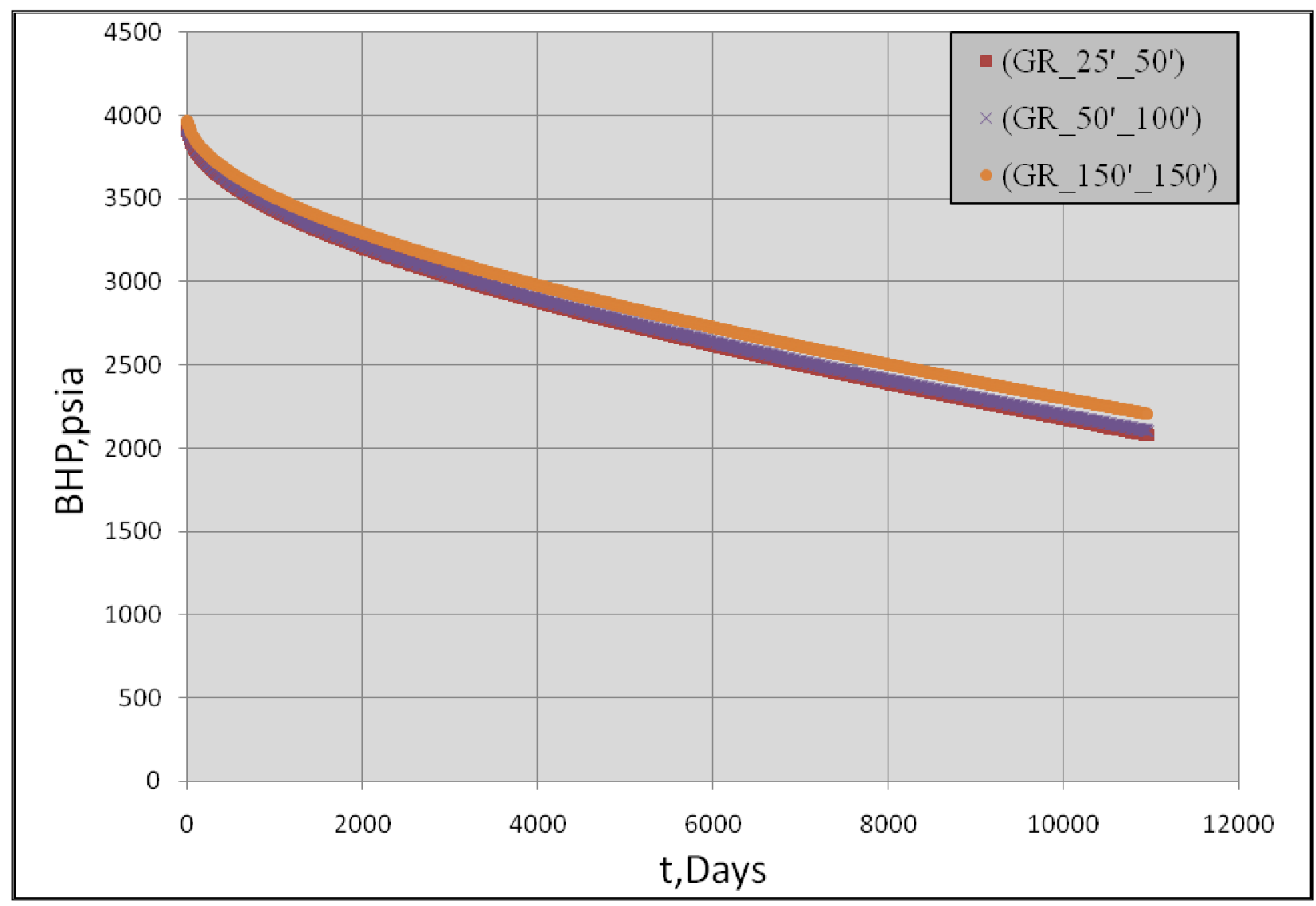

Figure III-9 Bottomhole flowing pressure versus time for a Tri - lateral well with eight fractures treatments $\left(\mathrm{x}_{\mathrm{f}}=200 \mathrm{ft}\right)$ tested by three different cell size limitations. 


\subsection{Analysis of the Results:}

The parameters that were used to analyze the results were taken from the reservoir simulation. The reservoir simulation was set to produce without any restrictions on the flow rate and the limit used was the bottomhole flowing pressure with a value of 500 psia (Lewis and Hughes, 2008).

The key output reservoir simulation parameters that were used to analyze the result are:

- Flow or production rate.

- Total production.

- Reservoir pressure (field pressure).

\subsubsection{Productivity Index:}

In this study, the effects of well configurations on productivity index were discussed and the productivity index used in the calculations is given by:

$$
\mathrm{J}=\frac{\mathrm{q}_{\mathrm{sc}}(\mathrm{t})}{\mathrm{m}\left(\mathrm{P}_{\text {Average Reservoir }}\right)-\mathrm{m}\left(\mathrm{P}_{\mathrm{BHP}}\right)}
$$

$\mathrm{q}_{\mathrm{sc}}(\mathrm{t})=$ Production rate (function of time) at standard conditions, Mscf/D.

$\mathrm{m}\left(\mathrm{P}_{\text {Average Reservoir }}\right)=$ Average reservoir pseudopressure, $\mathrm{MMpsi}^{2} / \mathrm{cp}$.

$\mathrm{m}\left(\mathrm{P}_{\mathrm{BHP}}\right)=$ Flowing bottomhole pseudopressure, $\mathrm{MMpsi}^{2} / \mathrm{cp}$.

\subsubsection{Flow Regimes:}

Flow regimes for the selected different well configurations were plotted in this research, so the effect of the different well configurations on the productivity index can be 
investigated by observing the change in the flow regimes or in the pressure transient. Pressure change and derivative of pressure change were plotted versus time to analyze the pressure transient responses for the different well configurations.

The pressure change $(\Delta \mathrm{m}(\mathrm{P}))$ is given by:

$\Delta \mathrm{m}(\mathrm{P})=\mathrm{m}(\mathrm{P})_{\text {Initial Reservoir Pressure }}-\mathrm{m}(\mathrm{P})_{\text {Field Pressure }}$

$(\mathrm{P})_{\text {Initial Reservoir Pressure }}=$ Initial reservoir pseudopressure, $\mathrm{MMpsi}^{2} / \mathrm{cp}$.

$\mathrm{m}(\mathrm{P})_{\text {Field Pressure }}=$ Field pseudopressure,$\frac{\mathrm{MMpsi}^{2}}{\mathrm{cp}}$

Field pressure is obtained from the reservoir simulator, which represents the average field/reservoir pressure at specific time.

\subsubsection{Total Field Production:}

The total production is plotted versus time for each well configuration and compared with the base case $(\mathrm{BC})$. The total production and pressure transient plots are used to confirm the results obtained from the productivity index schemes. 


\section{CHAPTER IV}

\section{RESULTS and DISCUSSION}

In this chapter, the results are obtained for different well configurations and the comparison is made between the base case and the other well configurations or designs.

\subsection{Base Case (BC) (Single horizontal well with 8 multi - stage hydraulic fractures):}

The pseudo pressure $(\Delta \mathrm{m}(\mathrm{P}))$ and its derivative $(\mathrm{d} \Delta \mathrm{m}(\mathrm{P}) / \mathrm{dlnt})$ for the base case with and without hydraulic fractures are shown in Figure IV-1 and Figure IV-2, respectively.

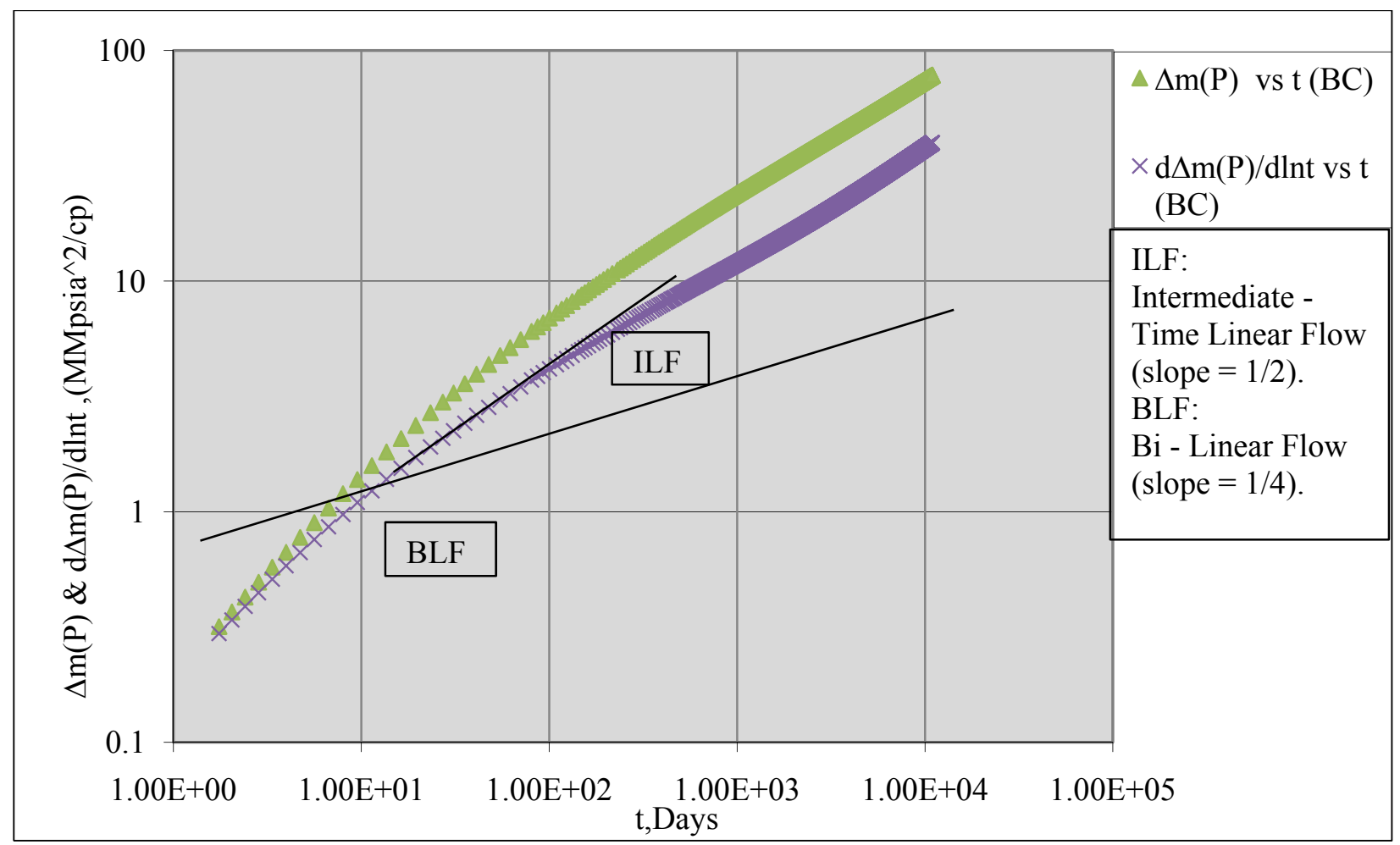

Figure IV-1 Pseudo pressure and its derivative for the (BC) with eight hydraulic fractures $\left(\mathrm{x}_{\mathrm{f}}=200 \mathrm{ft}\right)$. 
Figure IV-1 depicts the pseudo pressure and its derivative for the base case. The derivative has a straight line with slope of $(1 / 2)$ which reflects the linear flow from the reservoir to the hydraulic fractures. Straight line with slope of (1/4) was drawn in Figure IV-1, and it shows that there is no existence of the bi - linear flow regime. The well configurations used in this study do not show the bi - linear flow.

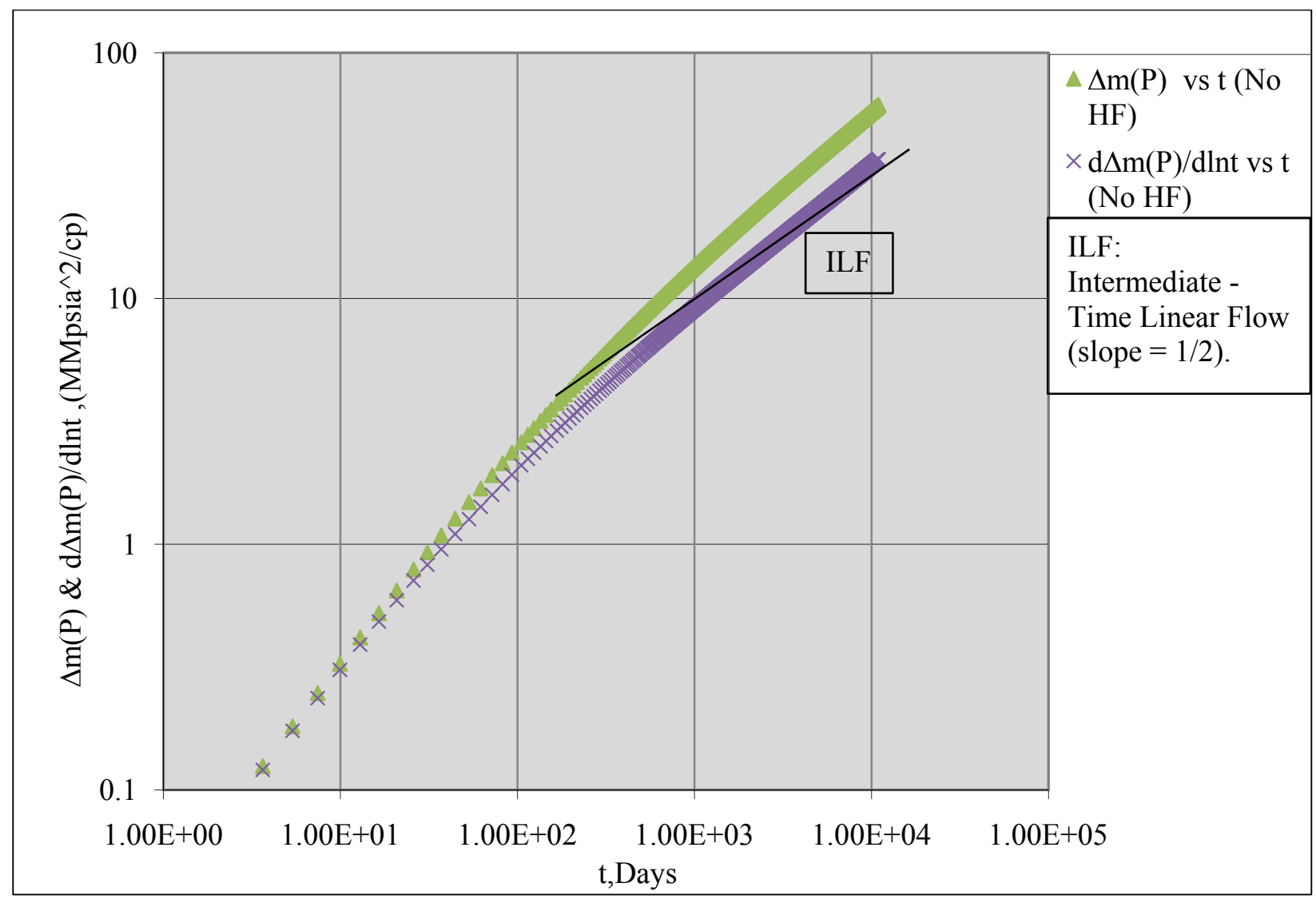

Figure IV-2 Pseudo pressure and its derivative for the $(\mathrm{BC})$ without hydraulic fractures. Figure IV-2 shows the base case without hydraulic fractures. The linear flow for this case occurred later than the base case Figure IV-3, because in the base case the linear flow represents flow to the hydraulic fractures, but in the base case without stimulation, the 
half slope line represents the linear flow from the reservoir to the horizontal well. The difference in time between the linear flow for the base case with and without stimulation is due to the additional pressure drop in the base case without stimulation than the base case with stimulation.

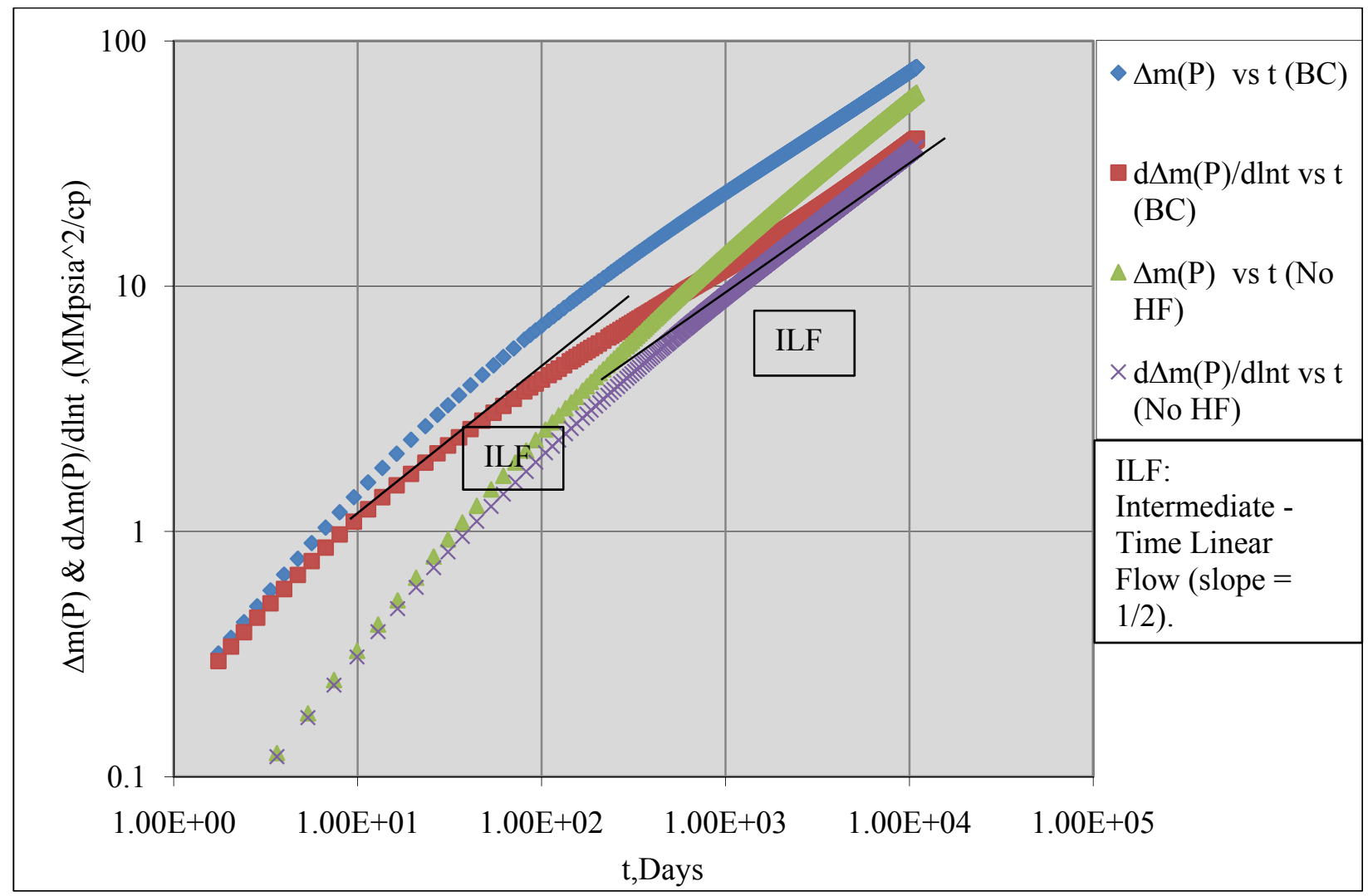

Figure IV-3 Pseudo pressure and its derivative for the (BC) with and without hydraulic fracture.

Figure IV-4 and Figure IV-5 show pressure distribution for the base case with and without hydraulic fractures respectively. It is clear that hydraulic fractures will decrease the time for linear flow to occur. 


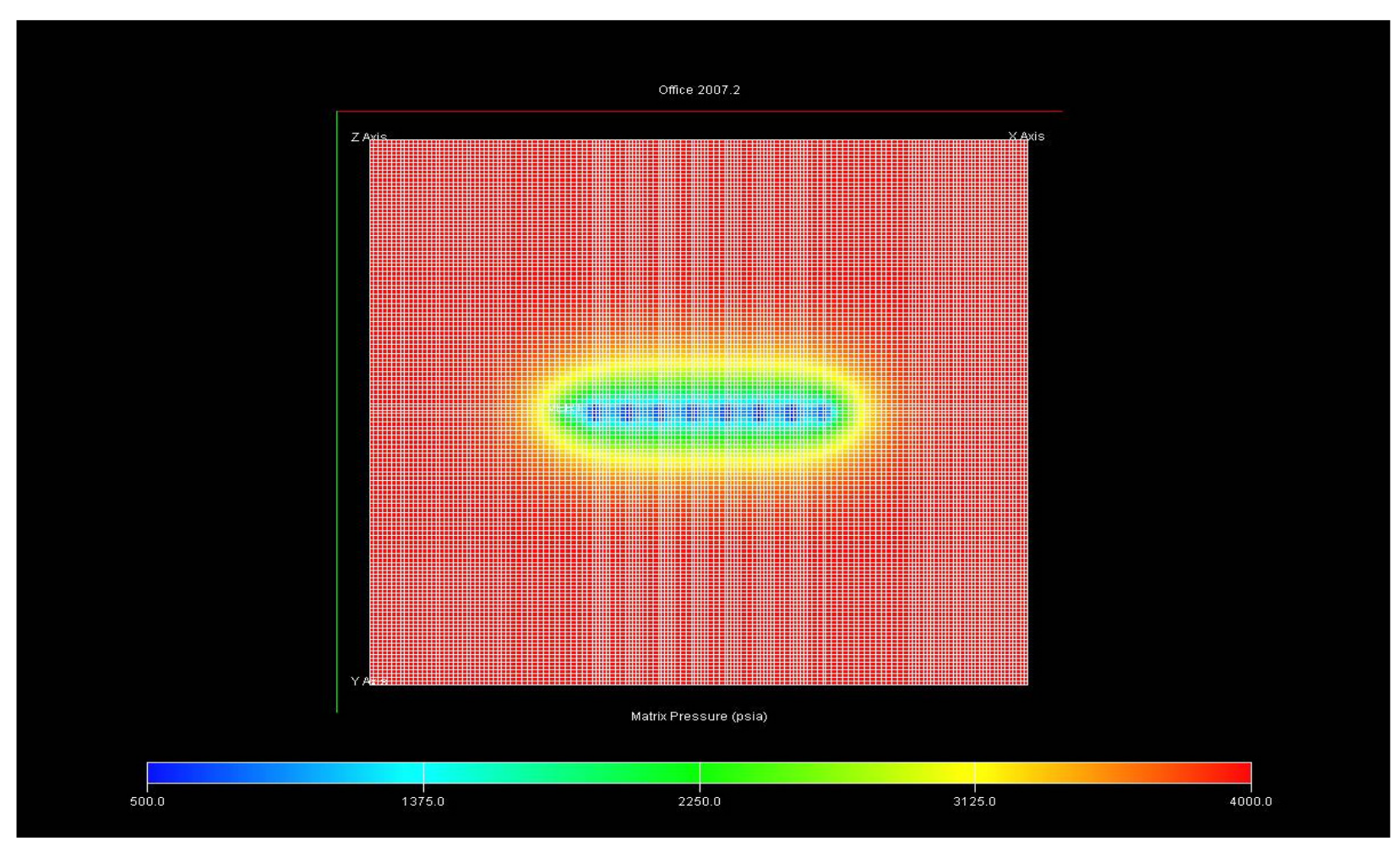

Figure IV-4 Pressure distribution for the $(\mathrm{BC})$ with eight hydraulic fractures $\left(\mathrm{x}_{\mathrm{f}}=200 \mathrm{ft}\right)$ at the end of 30 years. 


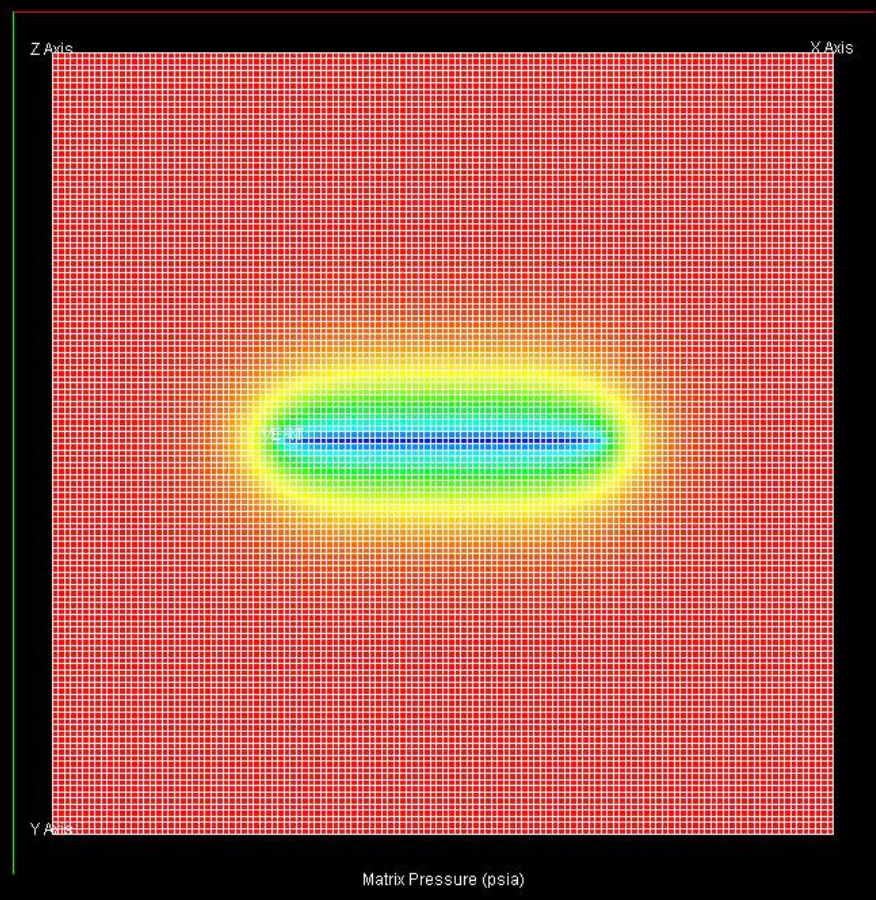

Figure IV-5 Pressure distribution for the (BC) without hydraulic fractures (HF) at the end of 30 years.

The productivity index for both base cases with and without hydraulic fracture is plotted in Figure IV-6. This figure shows the difference in productivity indices between the two cases. The productivity index for the base case with 8 multi - stages hydraulic fractures has better productivity than the base case without hydraulic fractures. 


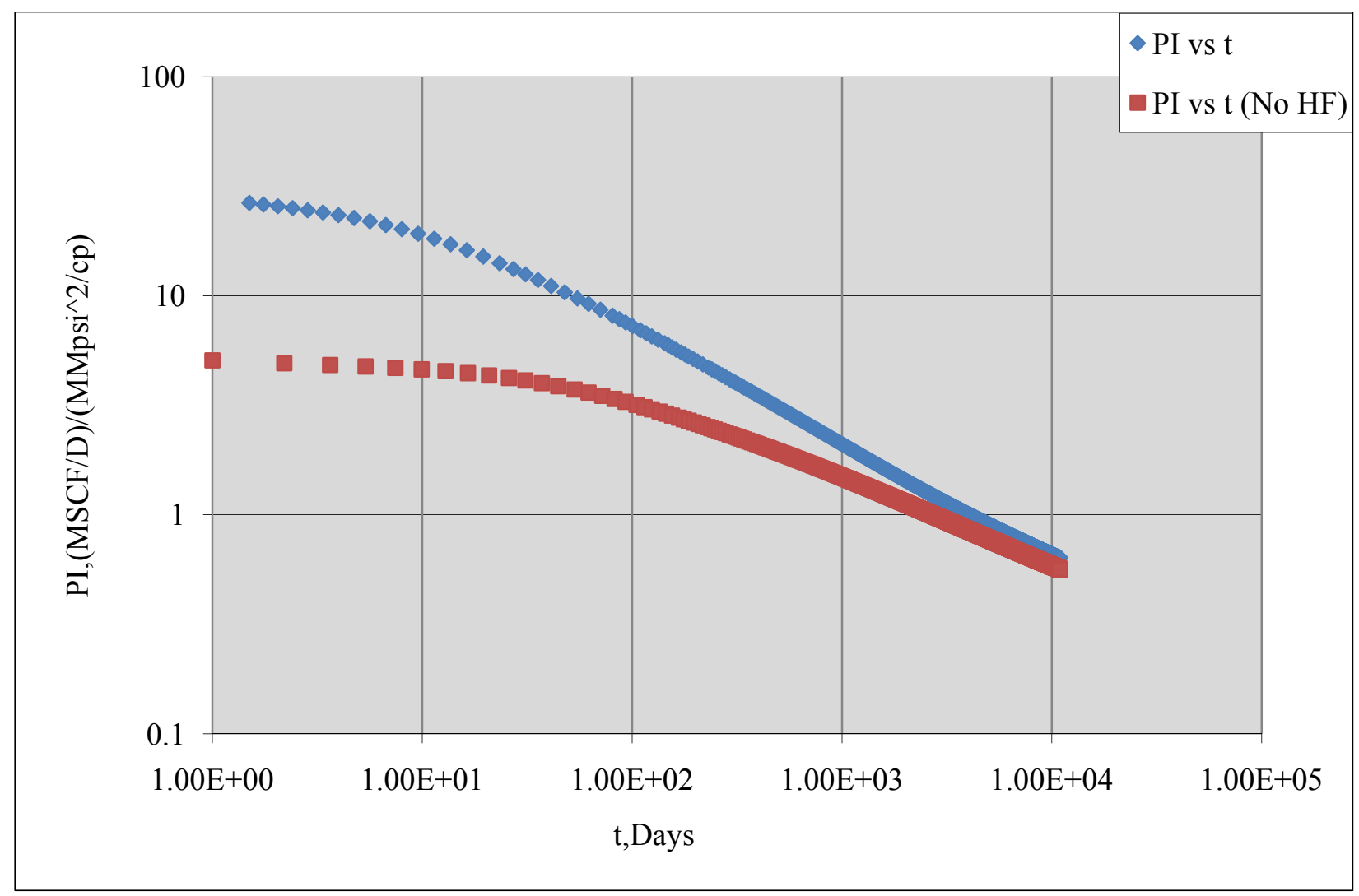

Figure IV-6 Productivity Index versus time for the (BC) with and without hydraulic fractures.

The improvement in the productivity index is a result of hydraulic fracturing, which accelerates the appearance of linear flow regime. This acceleration comes from increased connection between the formation and the horizontal well through the hydraulic fractures. As shown in Figure IV-6, the late time productivity index for the two cases are convergent; at late time hydraulic fractures affect decreases. 
Figure IV-7 shows the different in the total production between the base case with and without hydraulic fractures. It is clear that the base case with stimulation has more total production which confirmed the improvement in the productivity index.

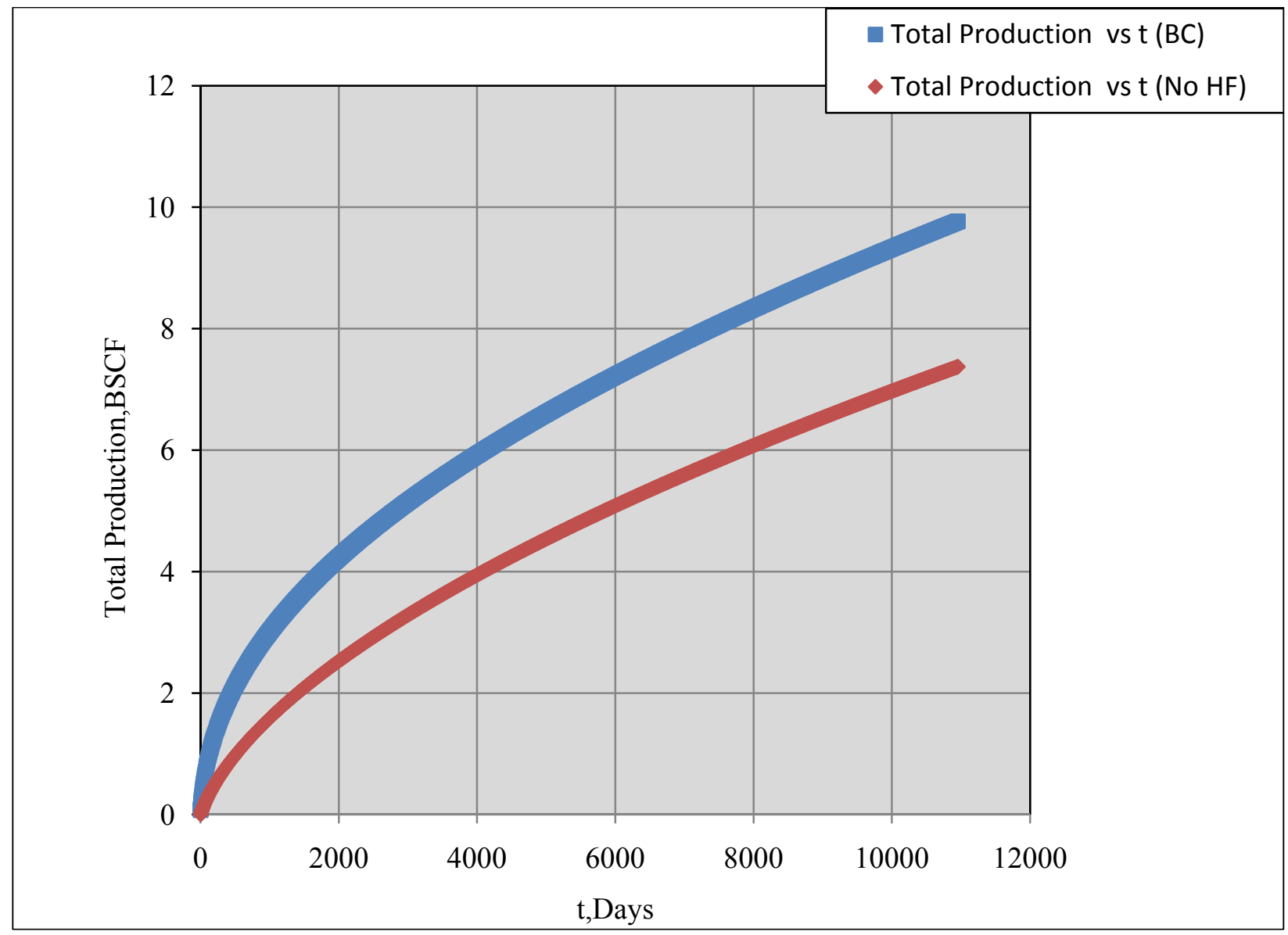

Figure IV-7 Total production versus time for the (BC) with and without hydraulic fractures. 


\subsection{Base Case (BC) versus Two parallel horizontal well (TPHW):}

Figure IV-8 shows pseudo pressure and its derivative for the two parallel horizontal well with four multi - stage hydraulic fractures on each well. Each well has a length of 2500 $\mathrm{ft}$, and the details were given in section (3.3.2). There is a similarity in the flow regimes between the (BC) and the (TPHW); these flow regimes are dominated by the linear flow to the hydraulic fractures. The pressure drop is greater in the (BC) than the (TPHW), because the $(\mathrm{BC})$ has lateral $(5000 \mathrm{ft})$ longer than the (TPHW) $(2500 \mathrm{ft}$ per each horizontal well).

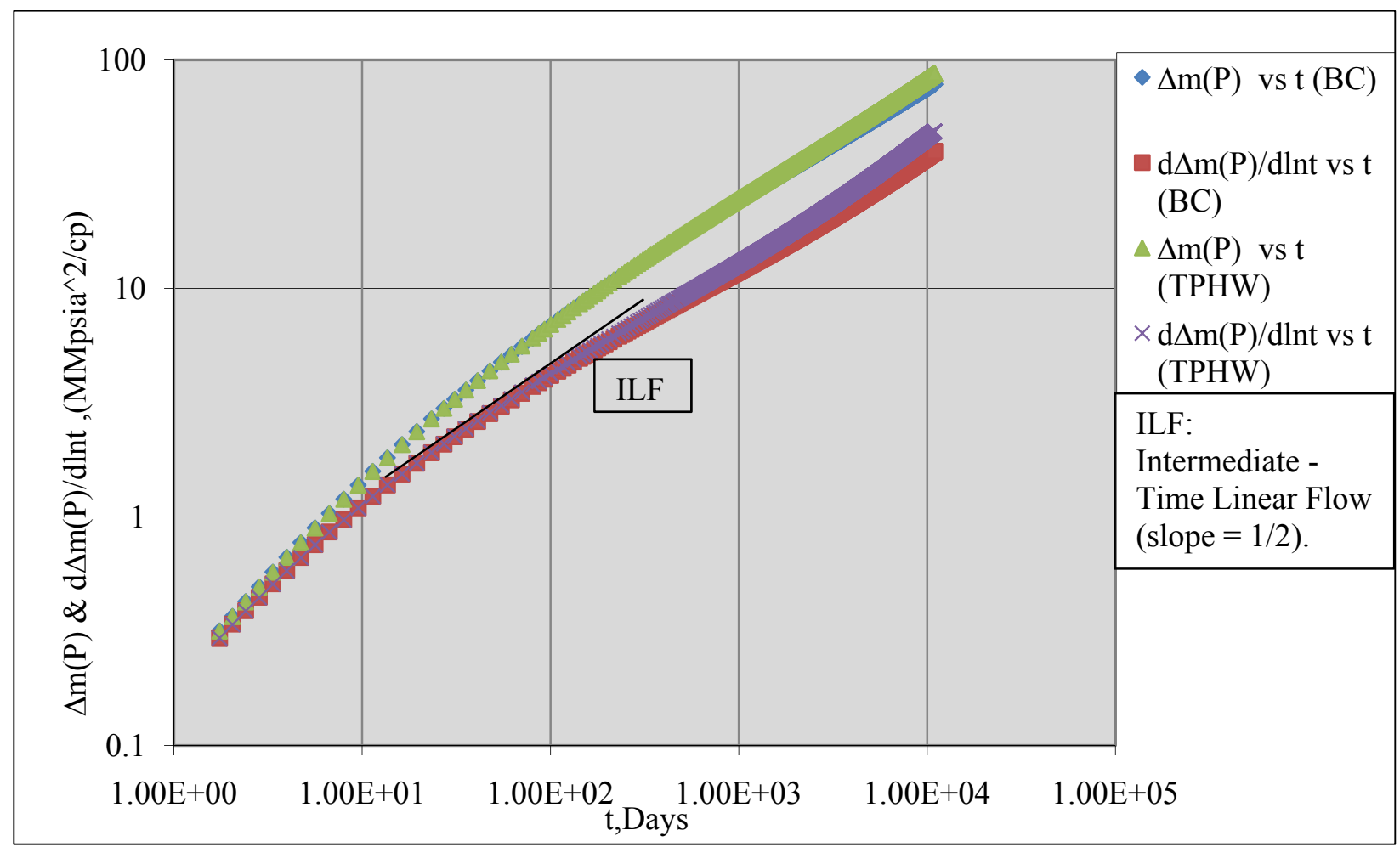

Figure IV-8 Pseudo pressure and its derivative for the (TPHW) and the (BC) with eight fracture treatment $\left(\mathrm{x}_{\mathrm{f}}=200 \mathrm{ft}\right)$. 
Productivity index for both (BC) and (TPHW) are plotted in Figure IV-9. The productivity indices at the first year are similar, then a slight deviation, resulted in a better productivity index for the (TPHW) than (BC) even with the same total lateral footage and the same eight multi - stages hydraulic fracture treatments. This difference in the productivity index confirmed the last interpretation for the pressure drop variation between the two cases. Figure IV-10 shows the total production for the two cases and it confirmed the same conclusion that (TPHW) has better productivity than the (BC).

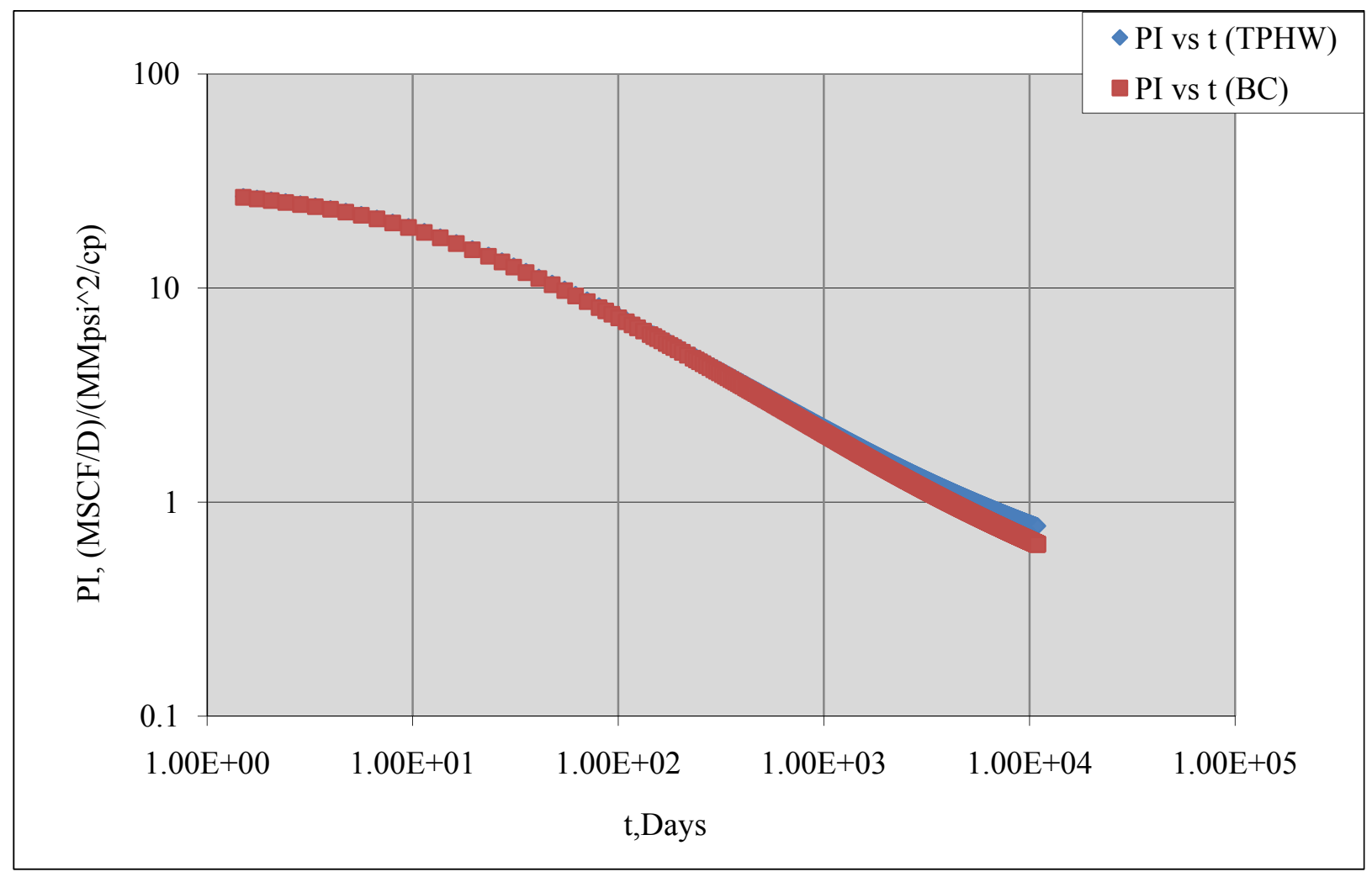

Figure IV-9 Productivity Index versus time for the (TPHW) and the (BC) with eight fracture treatment $\left(\mathrm{x}_{\mathrm{f}}=200 \mathrm{ft}\right)$. 


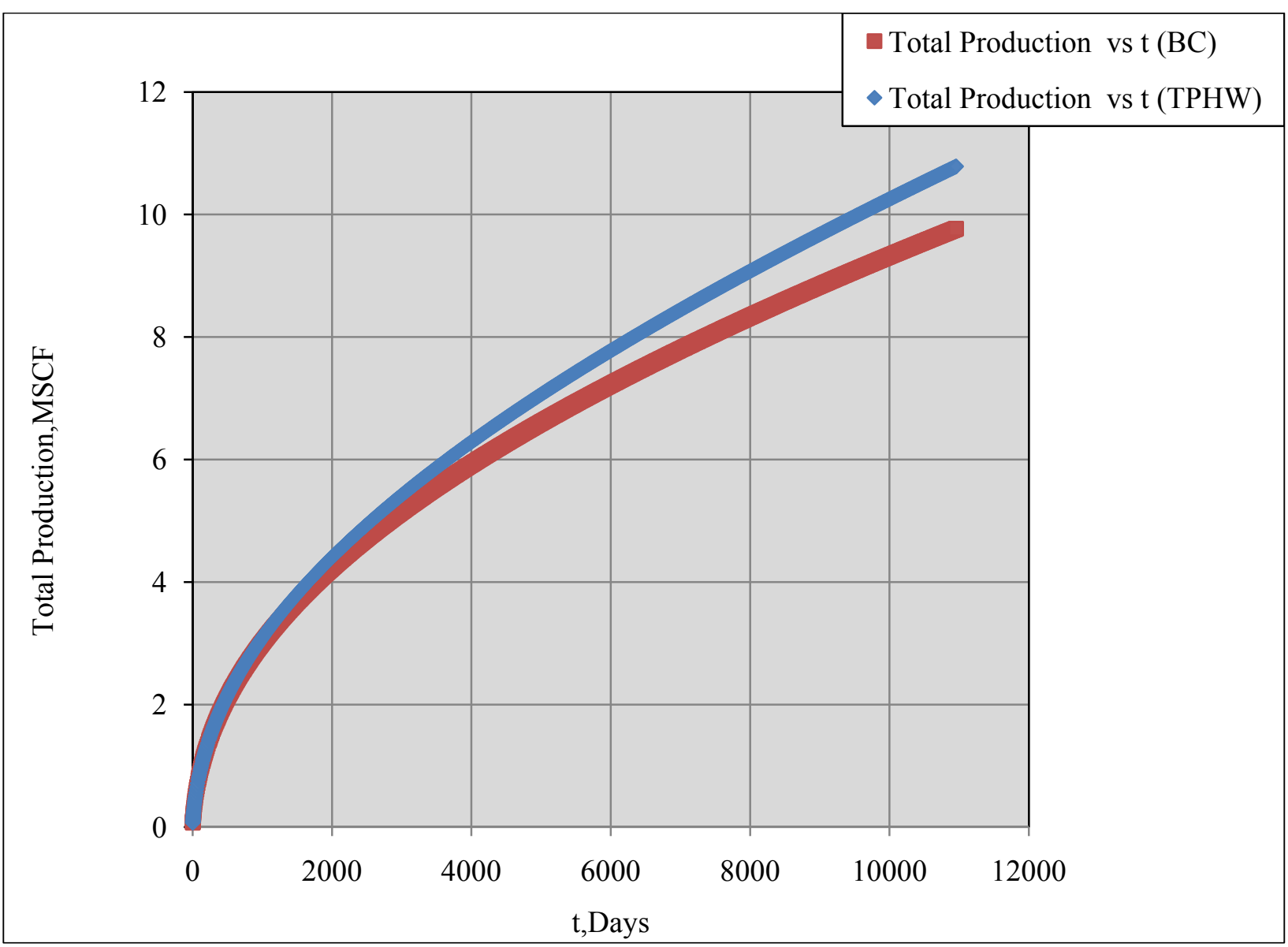

Figure IV-10 Total production versus time for the (TPHW) and the (BC) with eight fracture treatment $\left(\mathrm{x}_{\mathrm{f}}=200 \mathrm{ft}\right)$. 


\subsection{Base Case (BC) versus Dual - lateral well (DLW):}

Figure IV-11 shows pseudo pressure and its derivative for the dual - lateral well with four multi - stage hydraulic fractures on each lateral. Each lateral has a length of $2500 \mathrm{ft}$, and the details were given in section (3.3.3). There is a similarity between transitional (ILF) flow regimes for both the base case and dual - lateral well as shown in Figure IV12.This similarity indicates that pressure transient responses come from the induced multi - stage eight hydraulic fractures. The only different is occurred when the hydraulic fractures effect is decreased by the dominating flow from the reservoir to the horizontal well. There is a slightly more pressure drop in the base case $(\mathrm{BC})$ than the Dual lateral well (DLW).

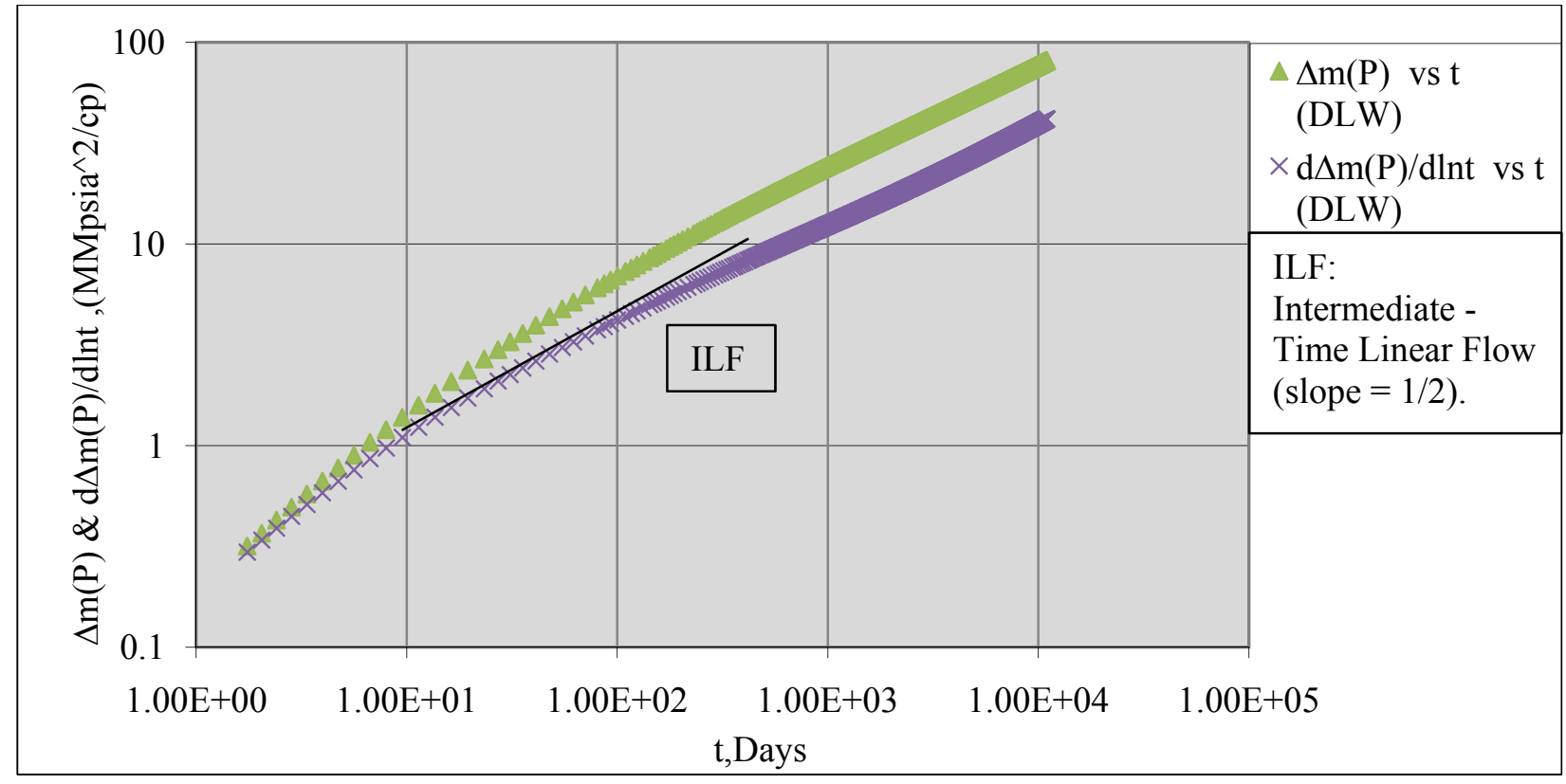

Figure IV-11 Pseudo pressure and its derivative for the (DLW) with eight fracture treatments $\left(\mathrm{x}_{\mathrm{f}}=200 \mathrm{ft}\right)$. 


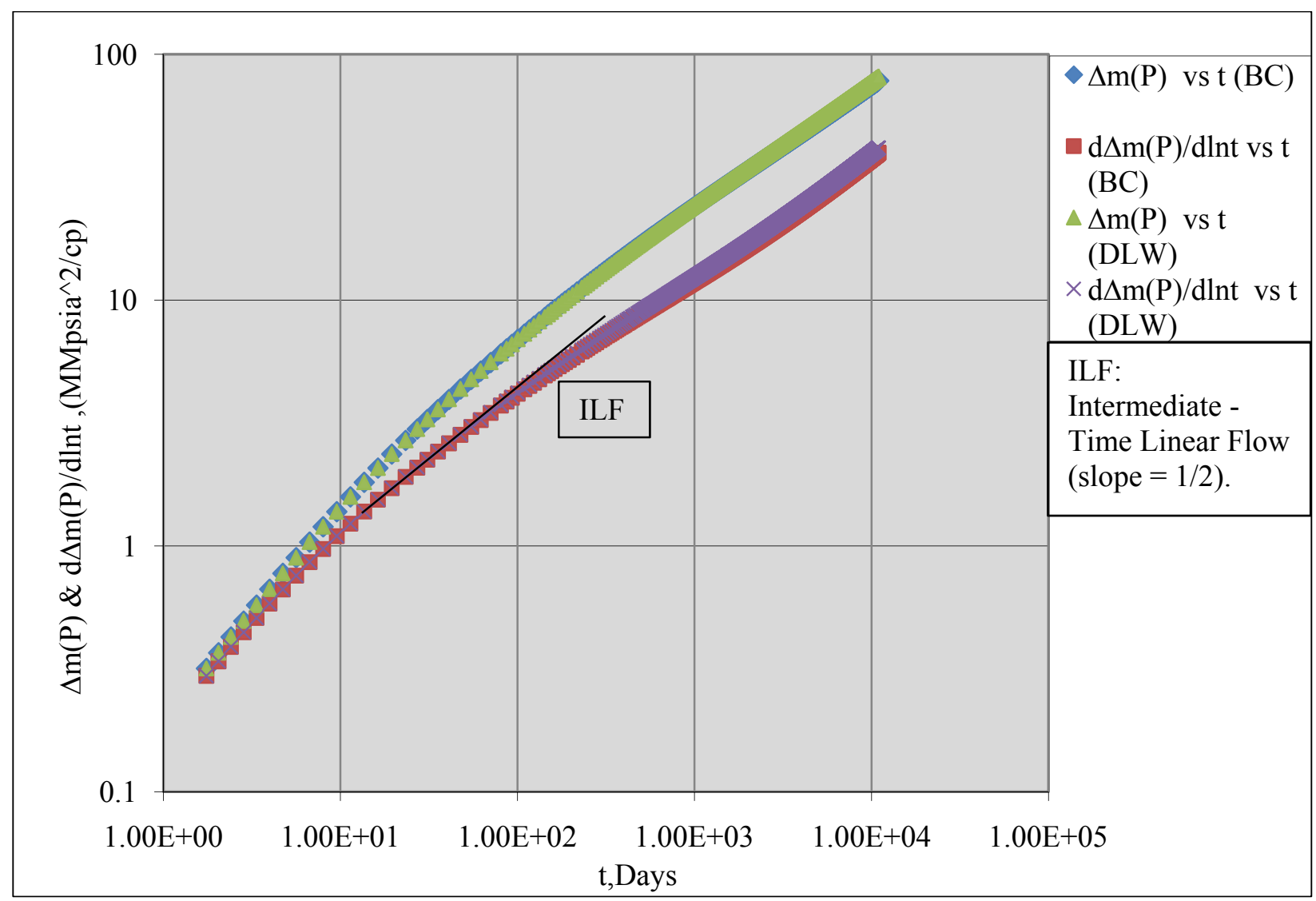

Figure IV-12 Pseudo pressure and its derivative for the (DLW) and the (BC) with eight fracture treatments $\left(\mathrm{x}_{\mathrm{f}}=200 \mathrm{ft}\right)$.

Productivity index for both base case and dual - lateral well are plotted in Figure IV-13. The productivity index for the both case is slightly similar with a little improvement for the (DLW) as the time increases.

Figure IV-14 shows the total production for the two cases with (DLW) has a slightly better productivity than the $(\mathrm{BC})$. 


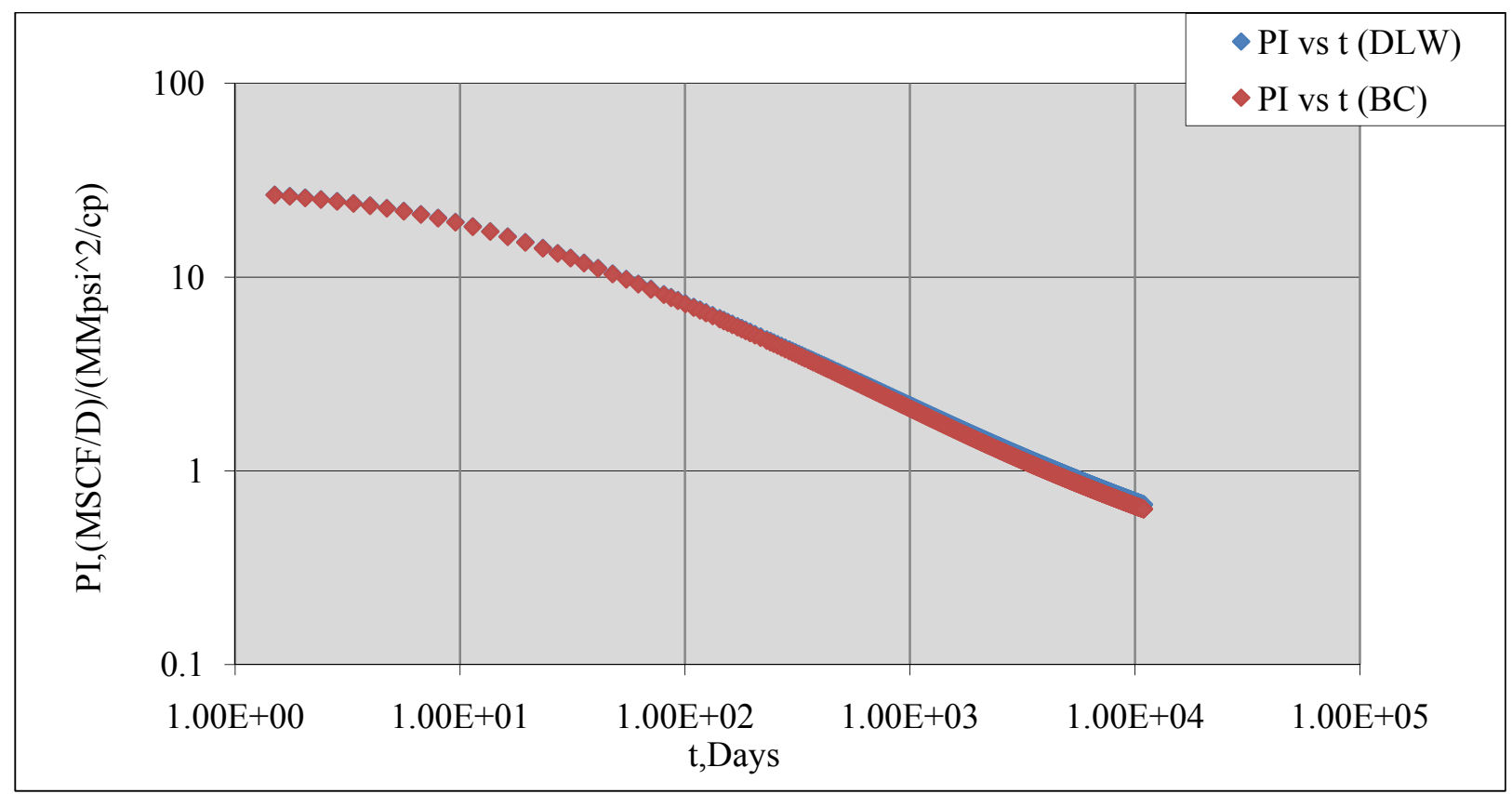

Figure IV-13 Productivity Index for the (DLW) and the (BC) with eight fracture treatments $\left(\mathrm{x}_{\mathrm{f}}=200 \mathrm{ft}\right)$.

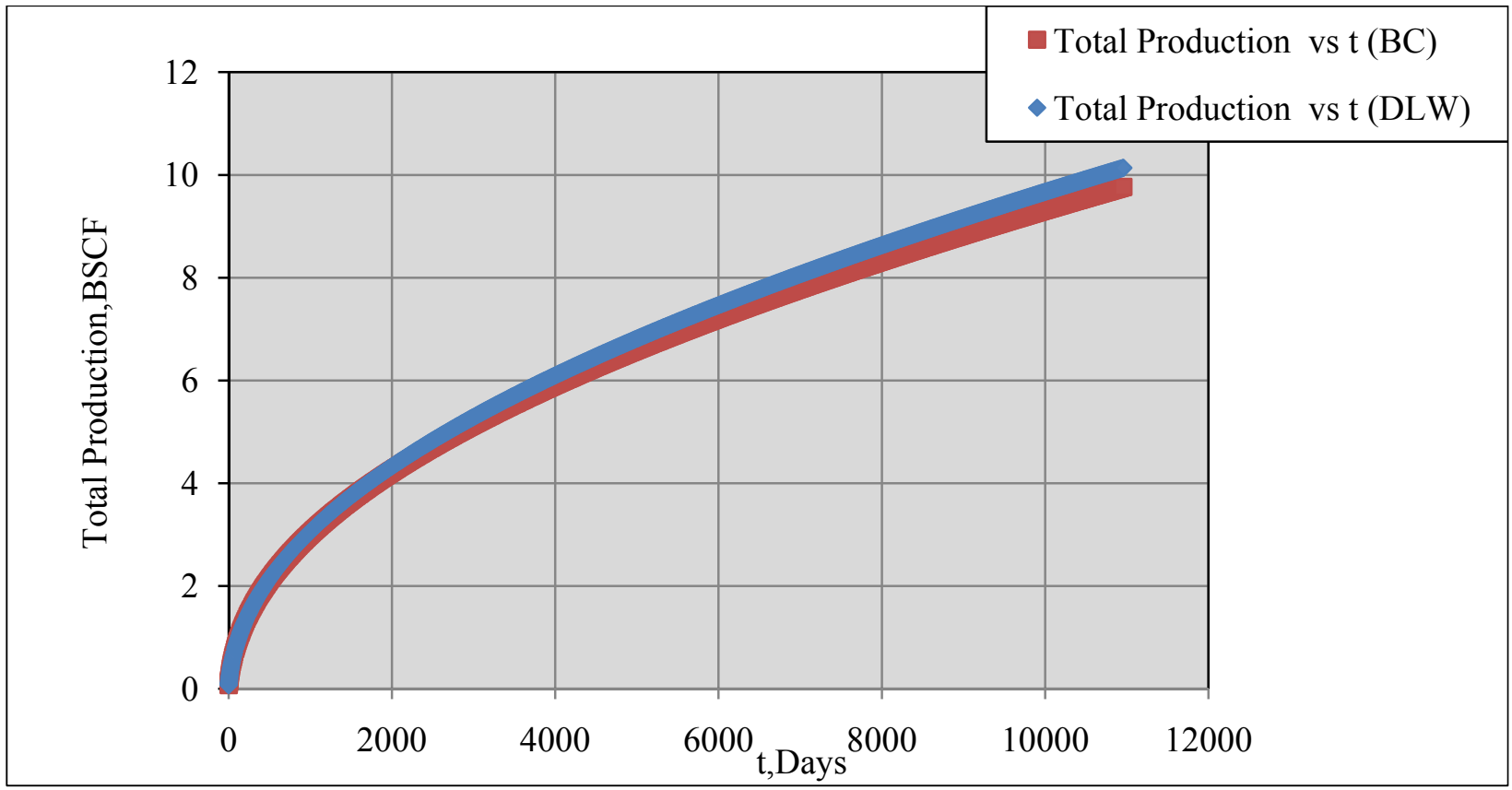

Figure IV-14 Total production versus time for the (DLW) and the (BC) with eight fracture treatments $\left(\mathrm{x}_{\mathrm{f}}=200 \mathrm{ft}\right)$. 


\subsection{Base Case (BC) versus V - well (VW):}

Figure IV-15 shows pseudo pressure and its derivative for the V - well with four multi stage hydraulic fractures on each lateral $2500 \mathrm{ft}$ long.

In Figure IV-16, except for the early time, the pseudo pressure and its derivative have similar transitional flow (ILF) for both base case and V- well. This similarity indicates that pressure transient responses come from the induced multi - stage eight hydraulic fractures.

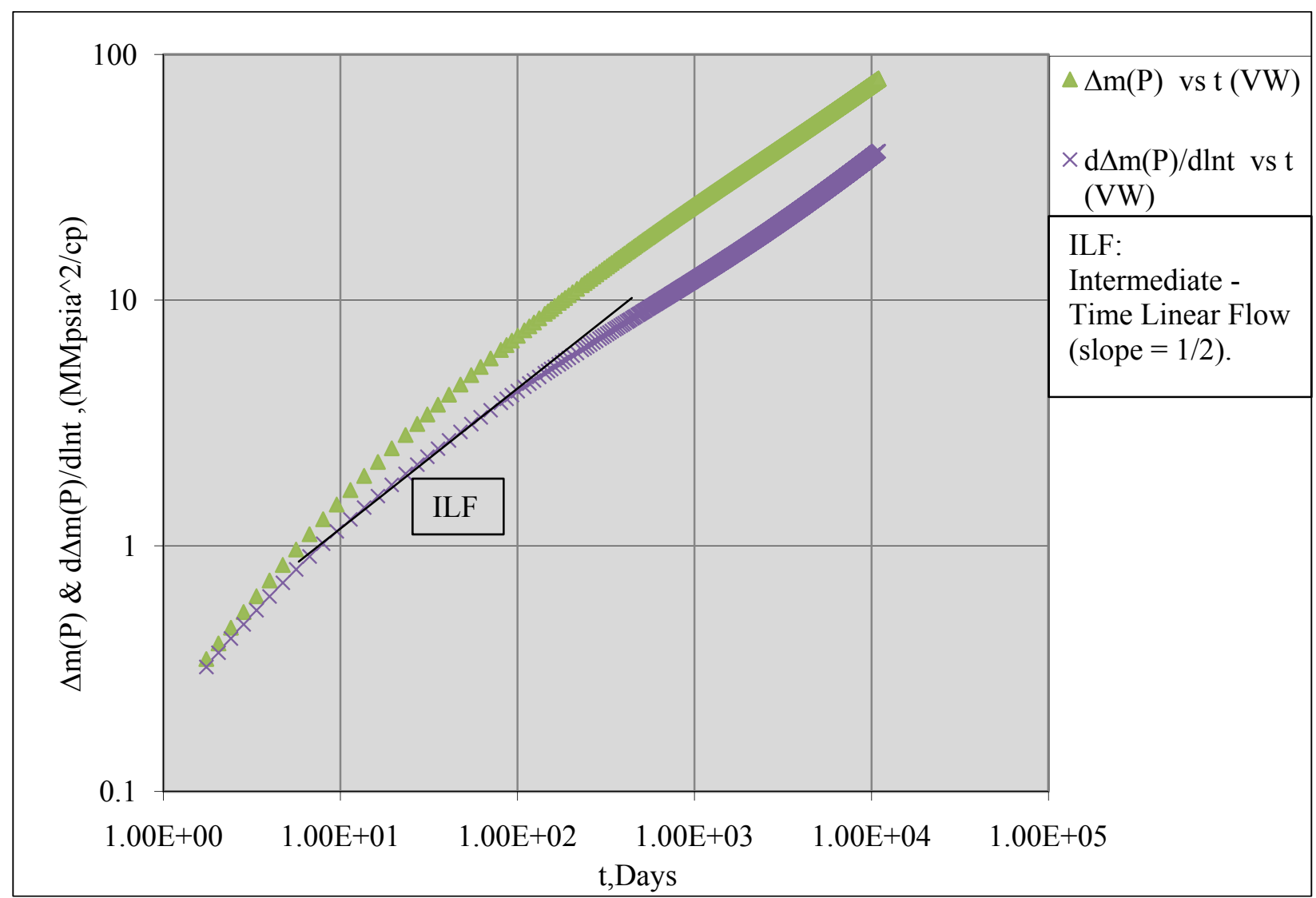

Figure IV-15 Pseudo pressure and its derivative for the (VW) with eight fracture treatments $\left(\mathrm{x}_{\mathrm{f}}=200 \mathrm{ft}\right)$. 


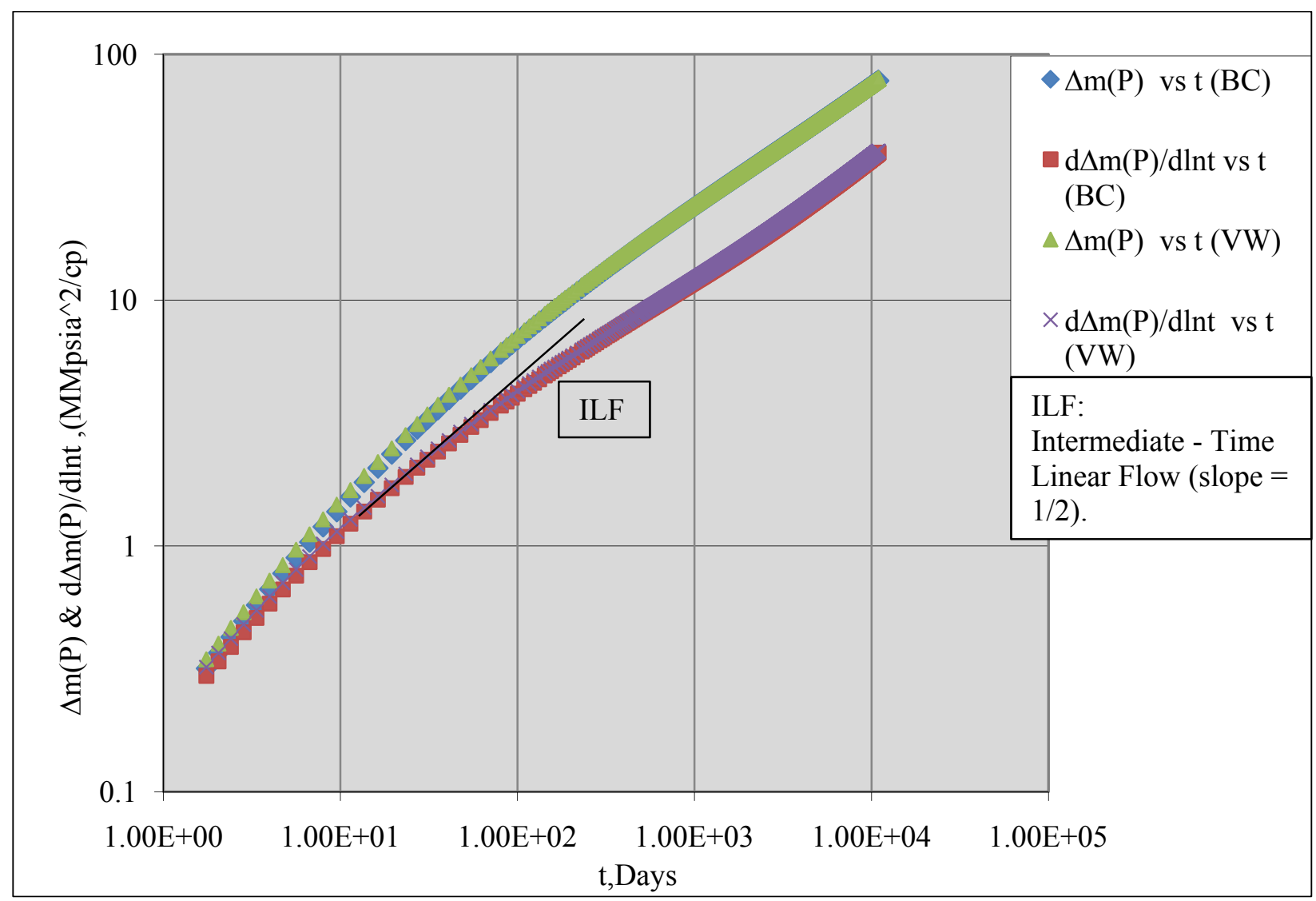

Figure IV-16 Pseudo pressure and its derivative for the (VW) and the (BC) with eight fracture treatments $\left(\mathrm{x}_{\mathrm{f}}=200 \mathrm{ft}\right)$.

Productivity index for both base case and V - well are plotted in Figure IV-17. The productivity indices are identical for the single horizontal lateral and the $\mathrm{V}$ - well except the early 100 days which resulted in slightly more total production for the (VW) than the (BC) as shown in Figure IV-18. 


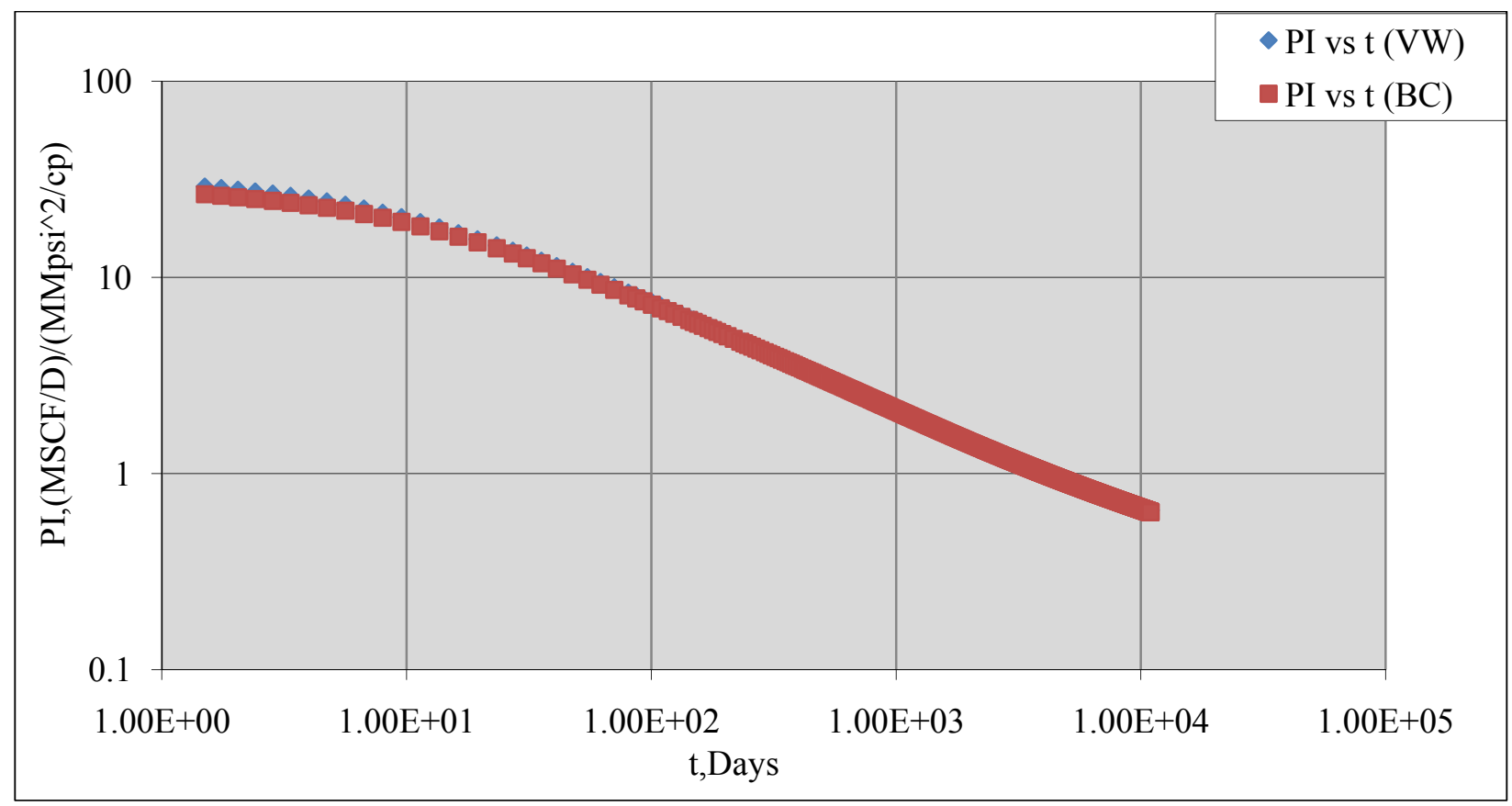

Figure IV-17 Productivity Index for the (VW) and the $(\mathrm{BC})$ with eight fracture treatments $\left(\mathrm{x}_{\mathrm{f}}=200 \mathrm{ft}\right)$.

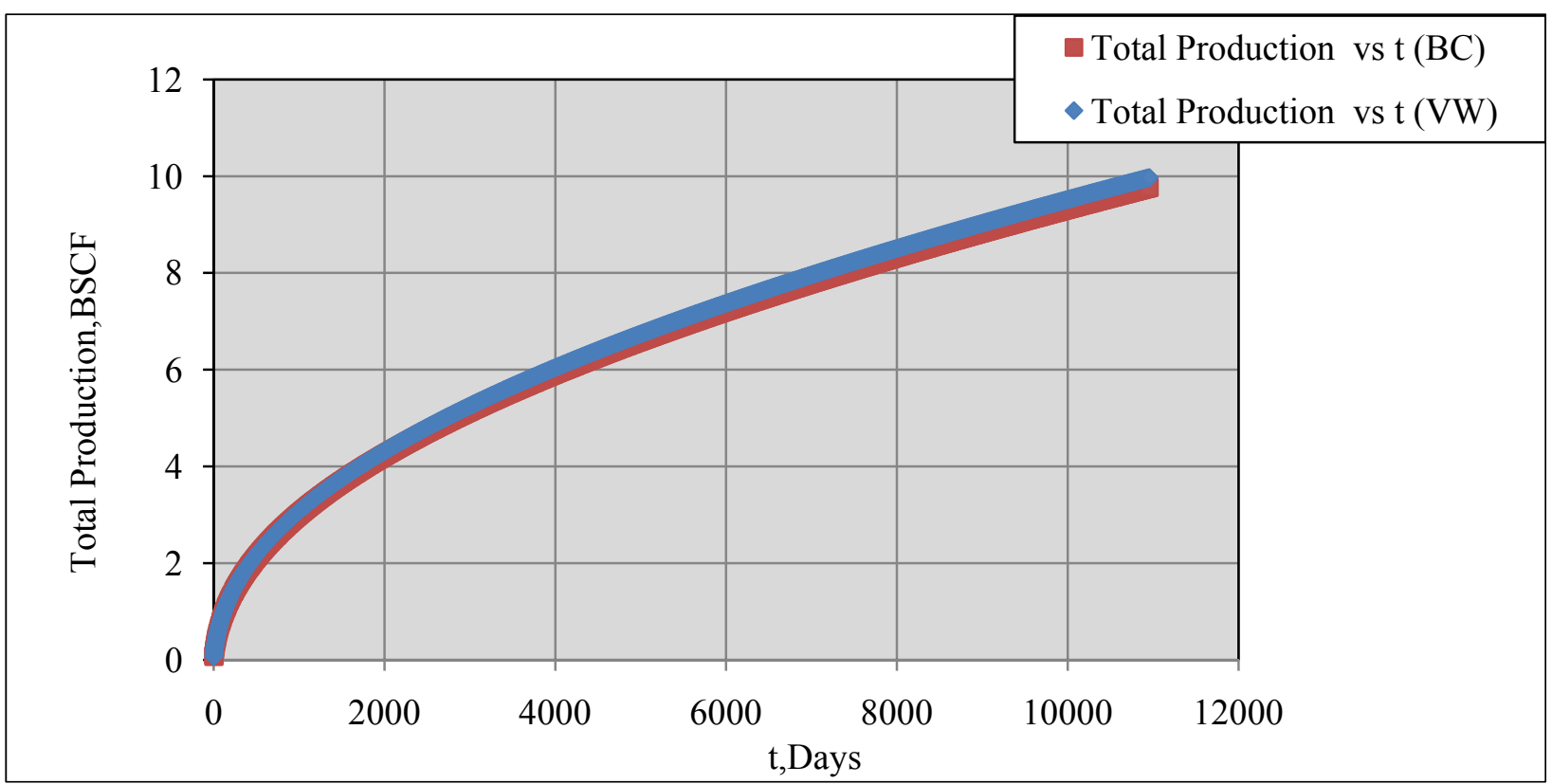

Figure IV-18 Total production versus time for the (VW) and the $(\mathrm{BC})$ with eight fracture treatments $\left(\mathrm{x}_{\mathrm{f}}=200 \mathrm{ft}\right)$. 


\subsection{Base Case (BC) versus Tri - lateral well (TLW):}

Figure IV-19 shows pseudo pressure and its derivative for the tri - lateral well. The details of tri-lateral well were given in section (3.3.5).

Figure IV-20, shows similar transitional flow (ILF) for the base case and tri - lateral well case. The similarity indicates that pressure transient responses come from the induced multi - stage eight hydraulic fractures. There are three laterals with a $1667 \mathrm{ft}$. per lateral for the case of (TLW) compared to $5000 \mathrm{ft}$ length for the (BC) and $2500 \mathrm{ft}$ length for each lateral for the (DLW). All these different well configurations had eight hydraulic fracture treatments. The (TLW) with its three lateral can be stimulated by more stages than the (BC) by stimulating each lateral individually as discussed later.

Productivity indices for both base case and tri - lateral well are plotted in Figure IV-21. The productivity index of tri - lateral well is similar to the base case.

Figure IV-22 shows the total production for both the (TLW) and the (BC) and it confirmed the above result that both cases have the same total production. 


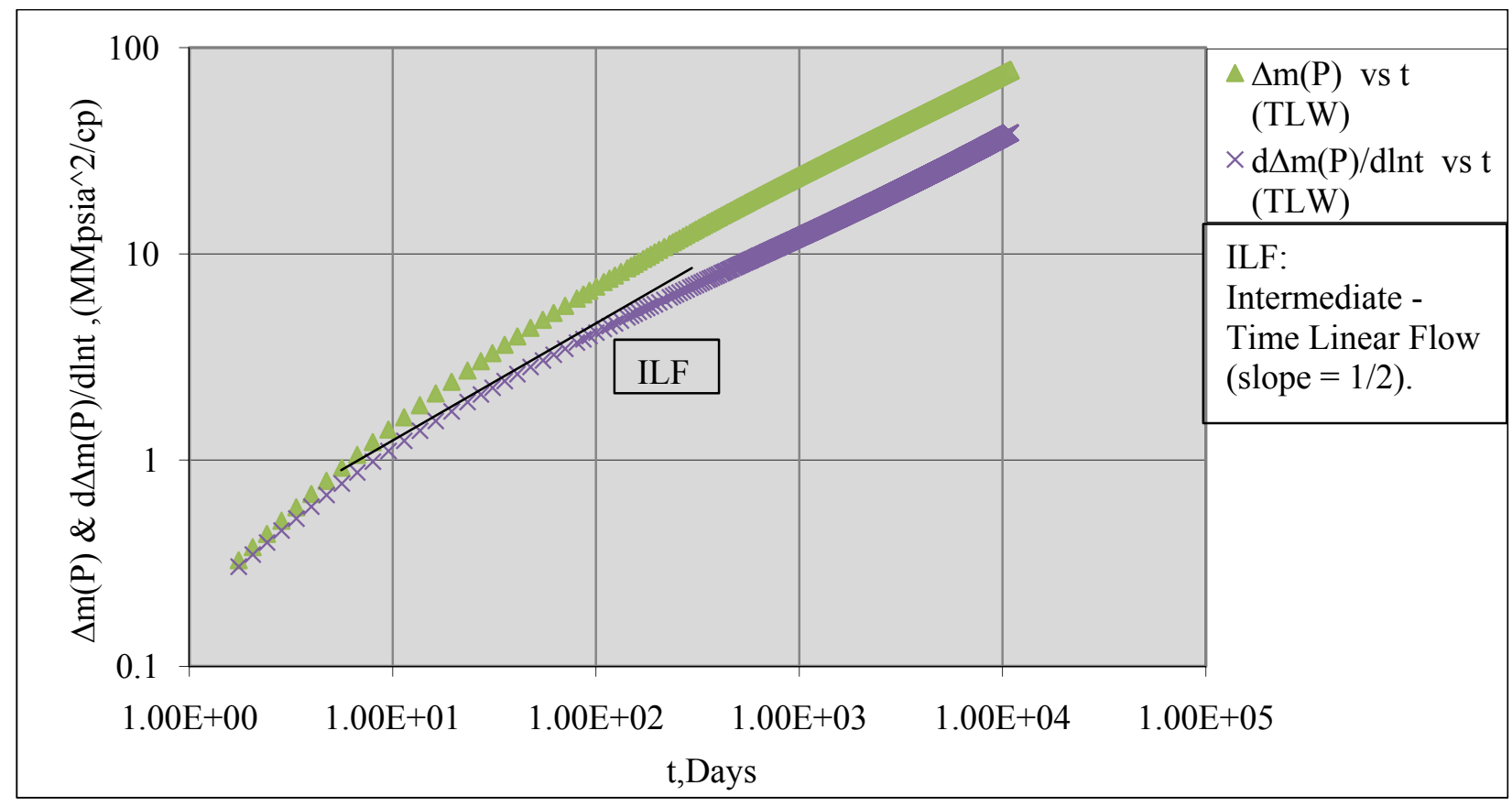

Figure IV-19 Pseudo pressure and its derivative for the (TLW) with eight fracture treatments $\left(\mathrm{x}_{\mathrm{f}}=200 \mathrm{ft}\right)$.

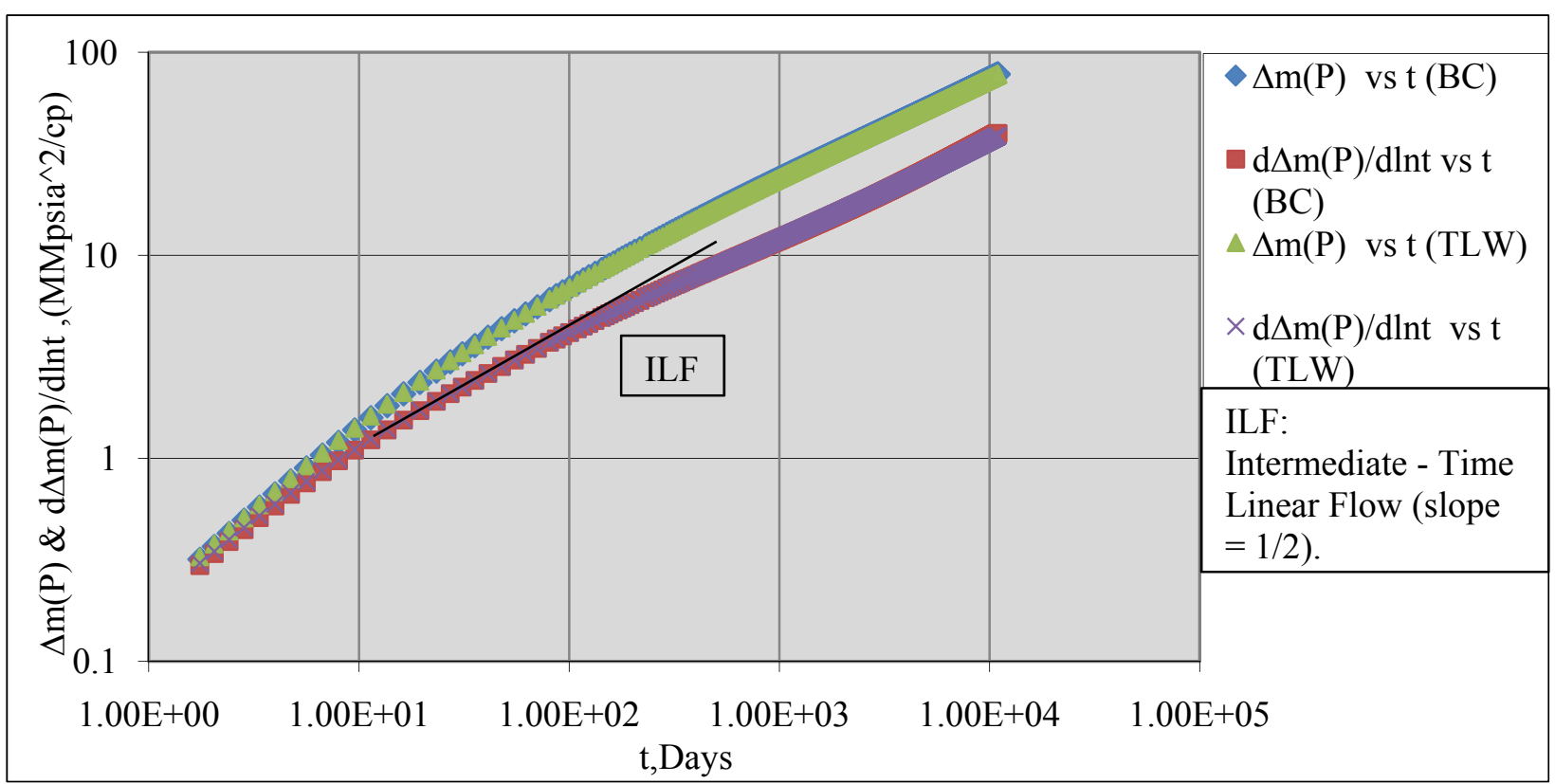

Figure IV-20 Pseudo pressure and its derivative for the (TLW) and the (BC) with eight fracture treatments $\left(\mathrm{x}_{\mathrm{f}}=200 \mathrm{ft}\right)$. 


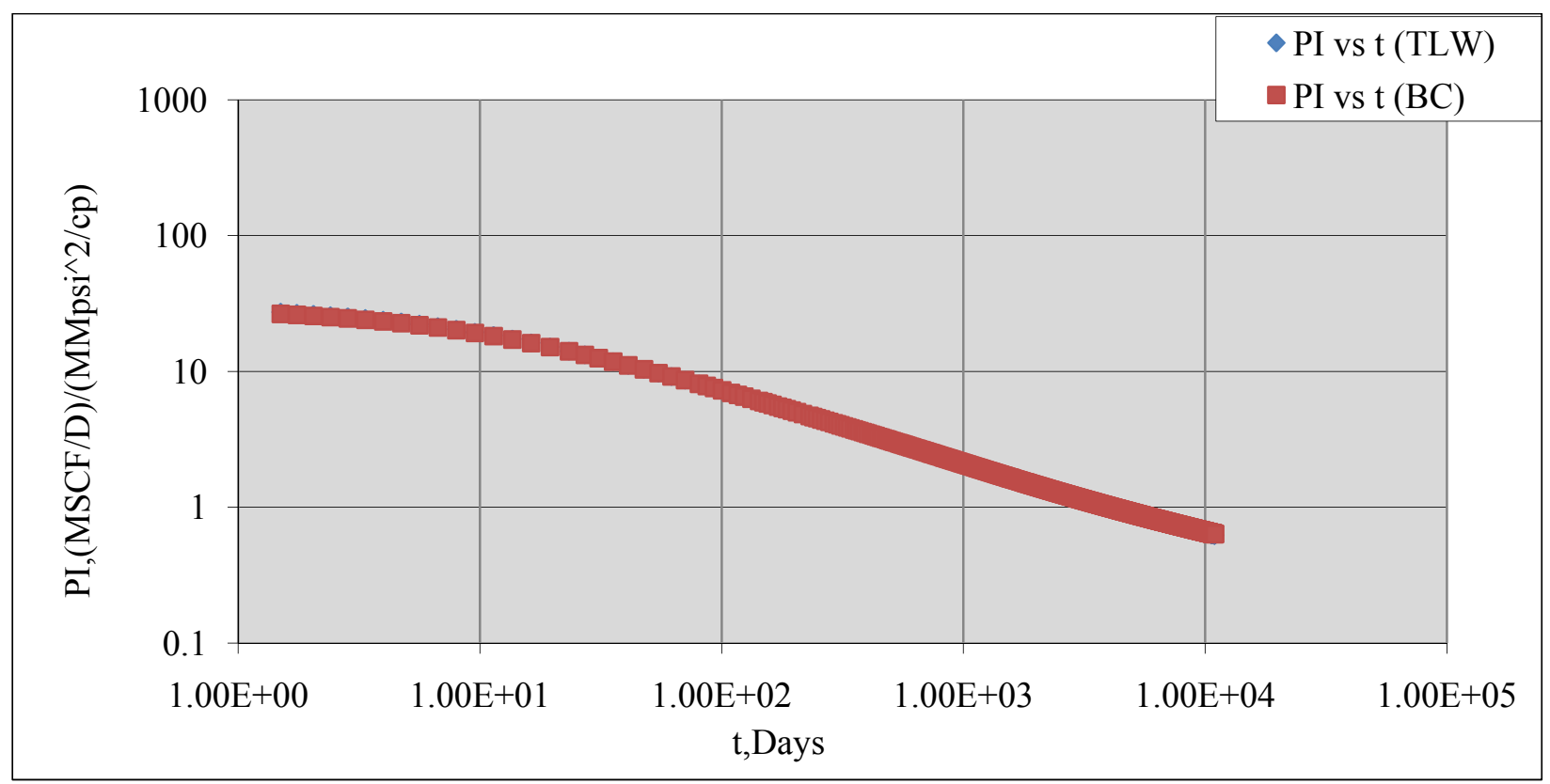

Figure IV-21 Productivity Index for the (TLW) and the (BC) with eight fracture treatments $\left(\mathrm{x}_{\mathrm{f}}=200 \mathrm{ft}\right)$.

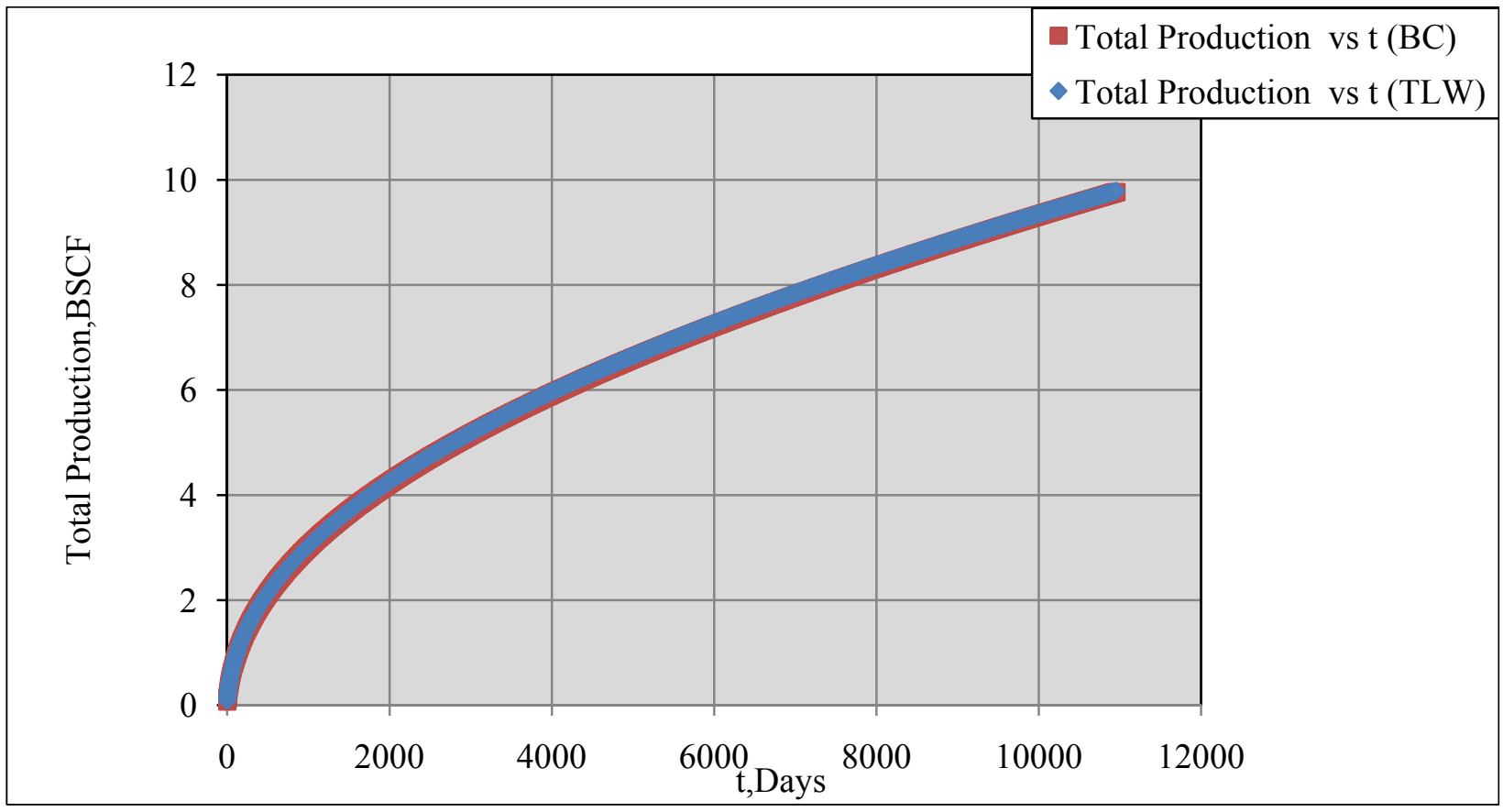

Figure IV-22 Total production versus time for the (TLW) and the (BC) with eight fracture treatments $\left(\mathrm{x}_{\mathrm{f}}=200 \mathrm{ft}\right)$. 


\subsection{Base case (BC) versus chicken foot - well (CFW):}

Figure IV-23 shows pseudo pressure and its derivative for the chicken foot- well design. The details were presented in section (3.3.6).

Figure IV-24 shows transitional flow (ILF) for the base case and chicken foot - well case. There is a similarity in transitional flow (ILF) indicating that pressure transient responses come from the linear flow from the reservoir to the induced multi - stage eight hydraulic fractures. At times beyond the first year, more pressure drop occurred in the case of (CFW). This pressure drop might be interpreted as a result of the interference between the laterals due to the laterals spacing which is shorter than the case of (TLW). Figure IV25 shows the pressure transient responses for the (CFW) and (TLW) and it is clear that (CFW) has more pressure drop than the (TLW). The (TLW) and (CFW) have the same lateral length and number of hydraulic fractures stages, but the laterals spacing is less in the case of $(\mathrm{CFW})$.

Productivity indices for both base case (BC) and chicken - foot well (CFW) are plotted in Figure IV-26. The productivity index of the $(\mathrm{BC})$ is better than the $(\mathrm{CFW})$, due to the more pressure drop in the case of (CFW).

Figure IV-27 shows the total production for both the $(\mathrm{CFW})$ and the $(\mathrm{BC})$. The $(\mathrm{BC})$ well configuration has production more than the $(\mathrm{CFW})$ well configuration. 


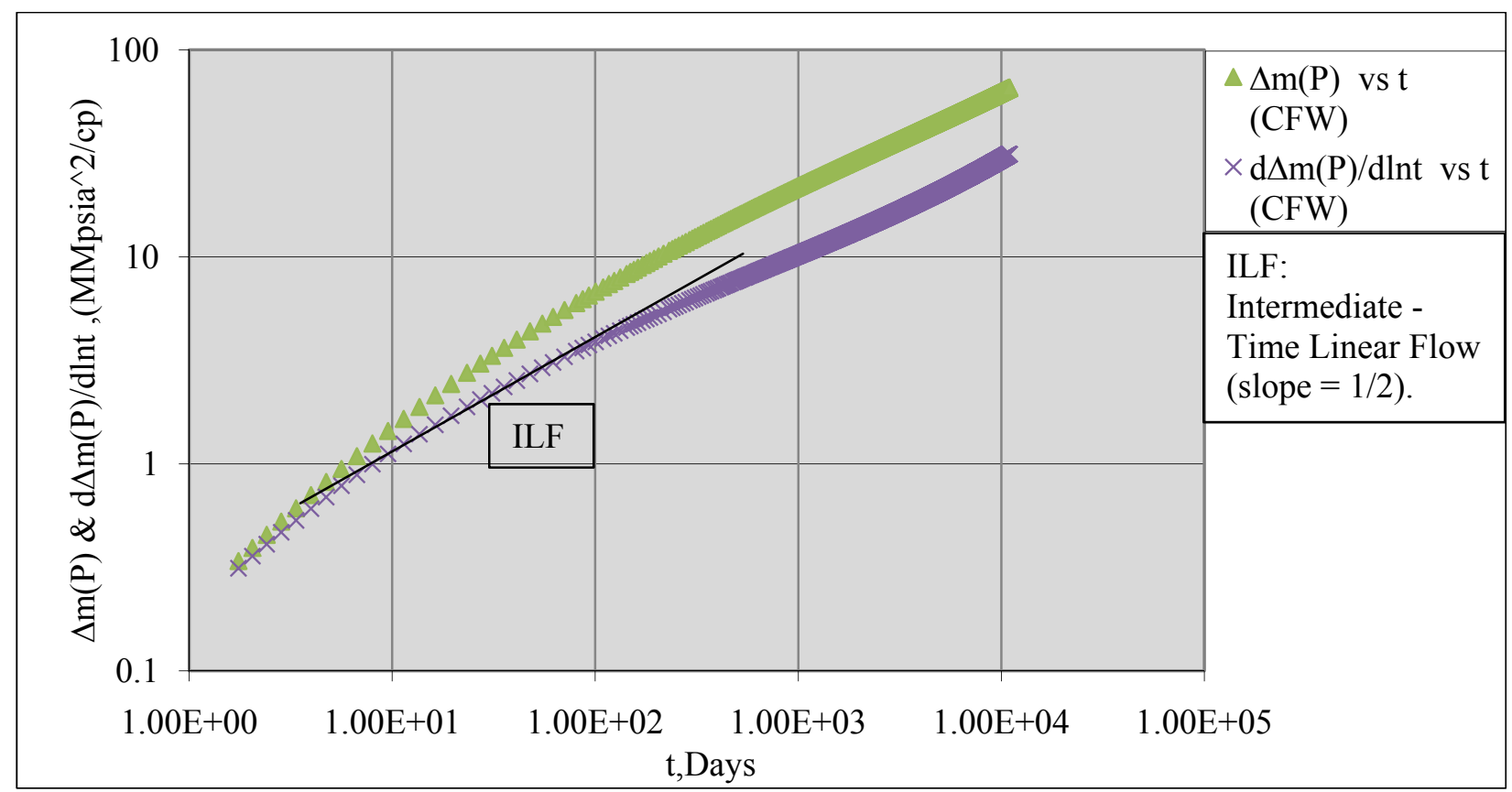

Figure IV-23 Pseudo pressure and its derivative for the (CFW) with eight fracture treatments $\left(\mathrm{x}_{\mathrm{f}}=200 \mathrm{ft}\right)$.

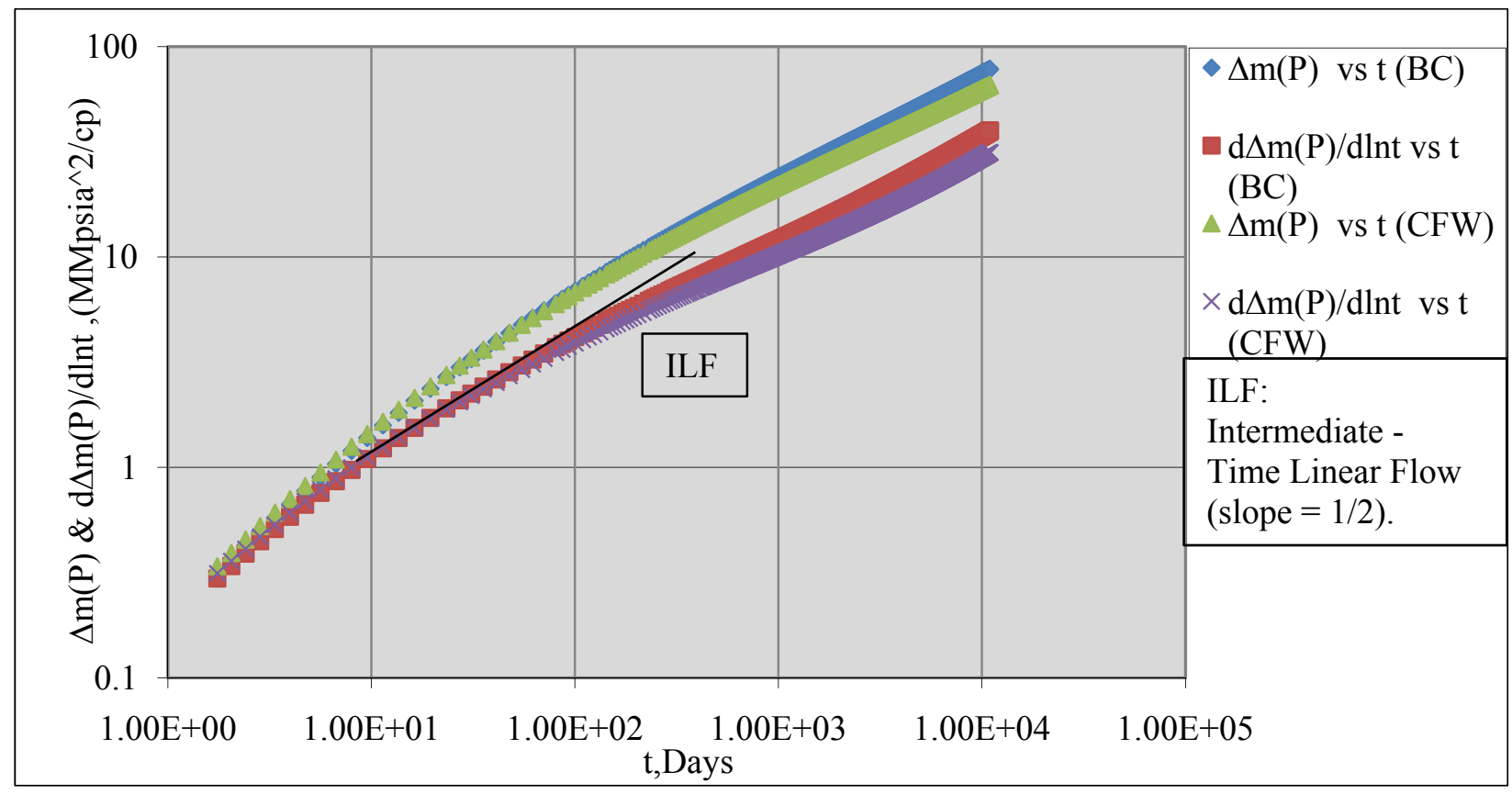

Figure IV-24 Pseudo pressure and its derivative for the (CFW) and the (BC) with eight fracture treatments $\left(\mathrm{x}_{\mathrm{f}}=200 \mathrm{ft}\right)$. 


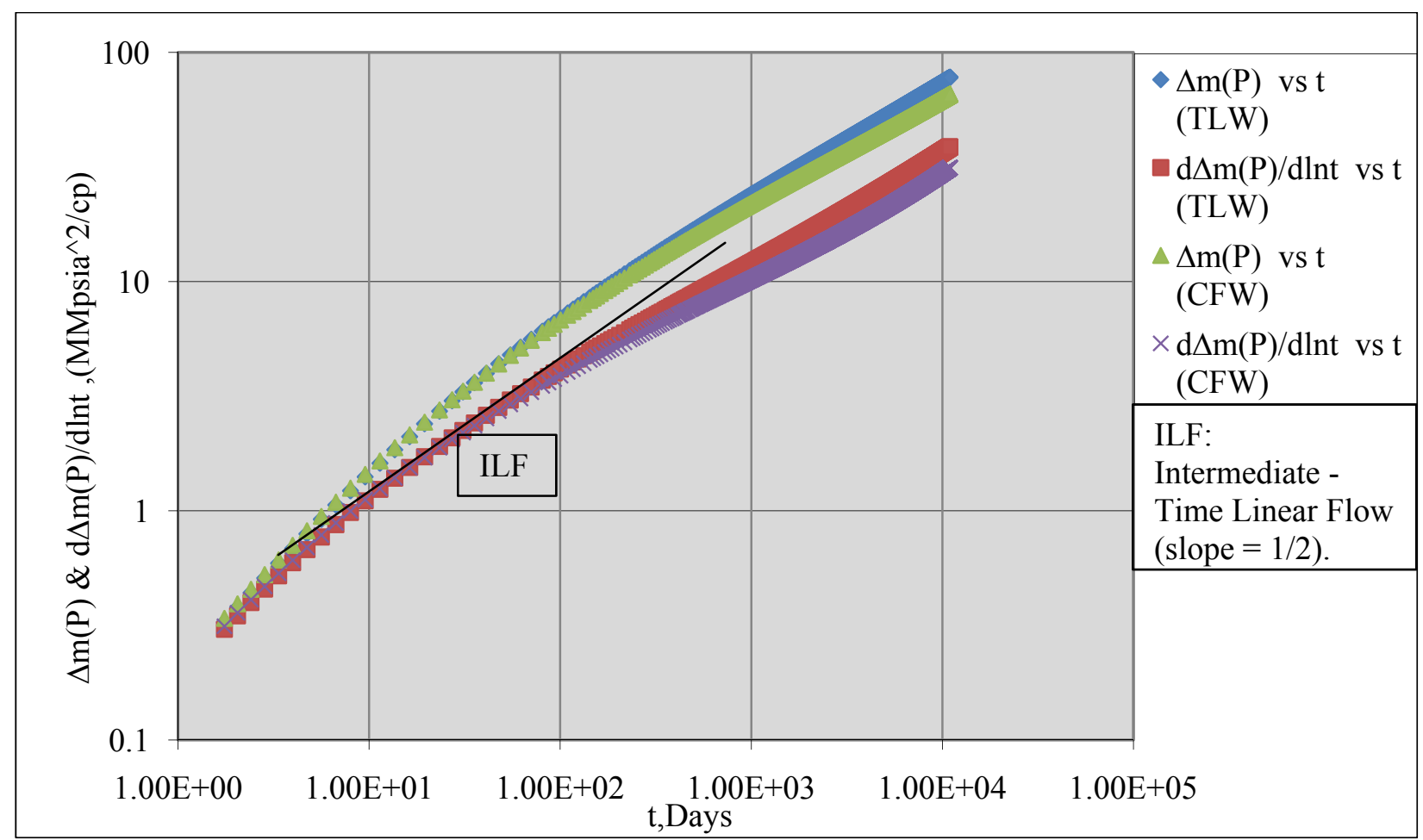

Figure IV-25 Pseudo pressure and its derivative for the (CFW) and (TLW) with eight fracture treatments $\left(\mathrm{x}_{\mathrm{f}}=200 \mathrm{ft}\right)$.

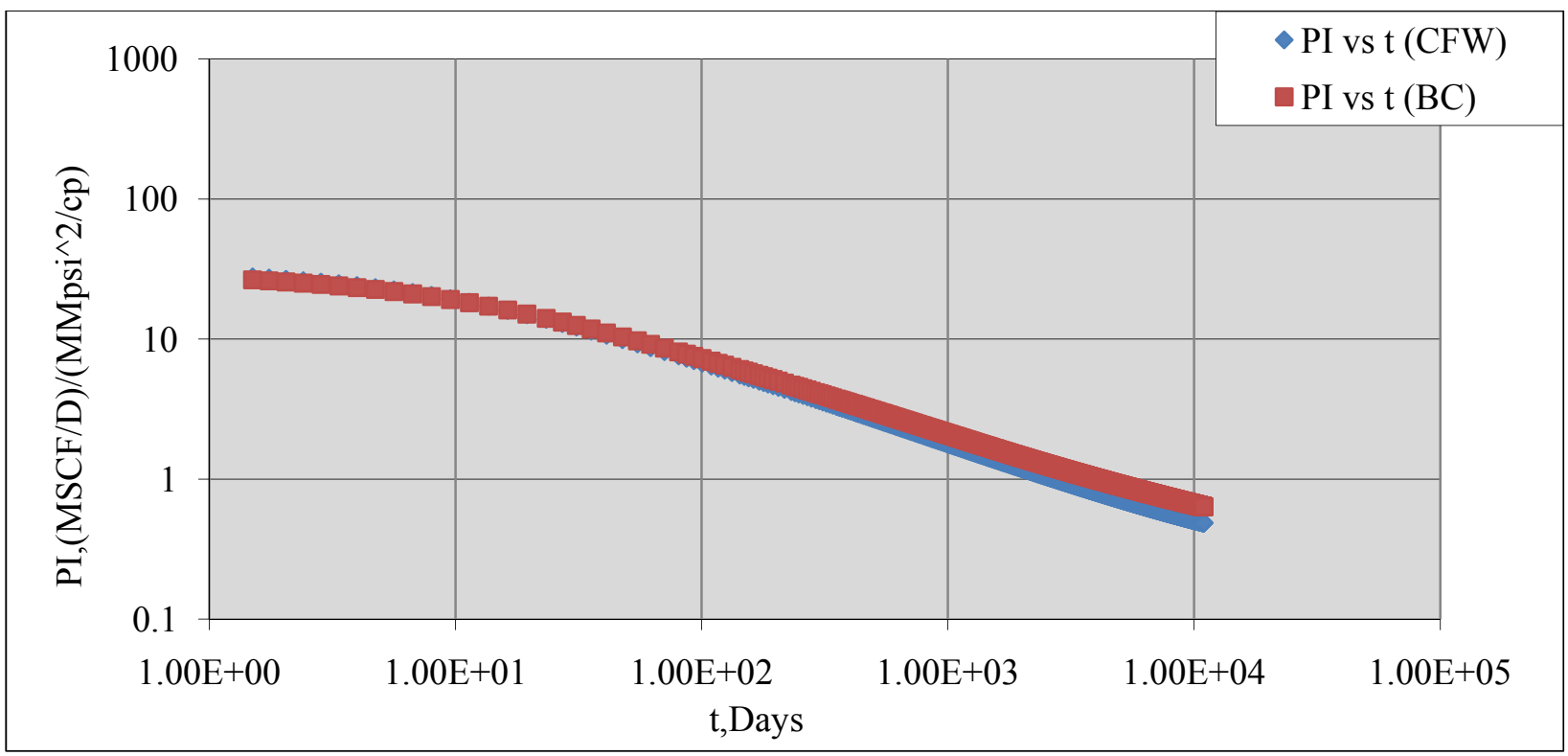

Figure IV-26 Productivity Index for the (CFW) and $(\mathrm{BC})$ with eight fracture treatments $\left(\mathrm{x}_{\mathrm{f}}=200 \mathrm{ft}\right)$. 


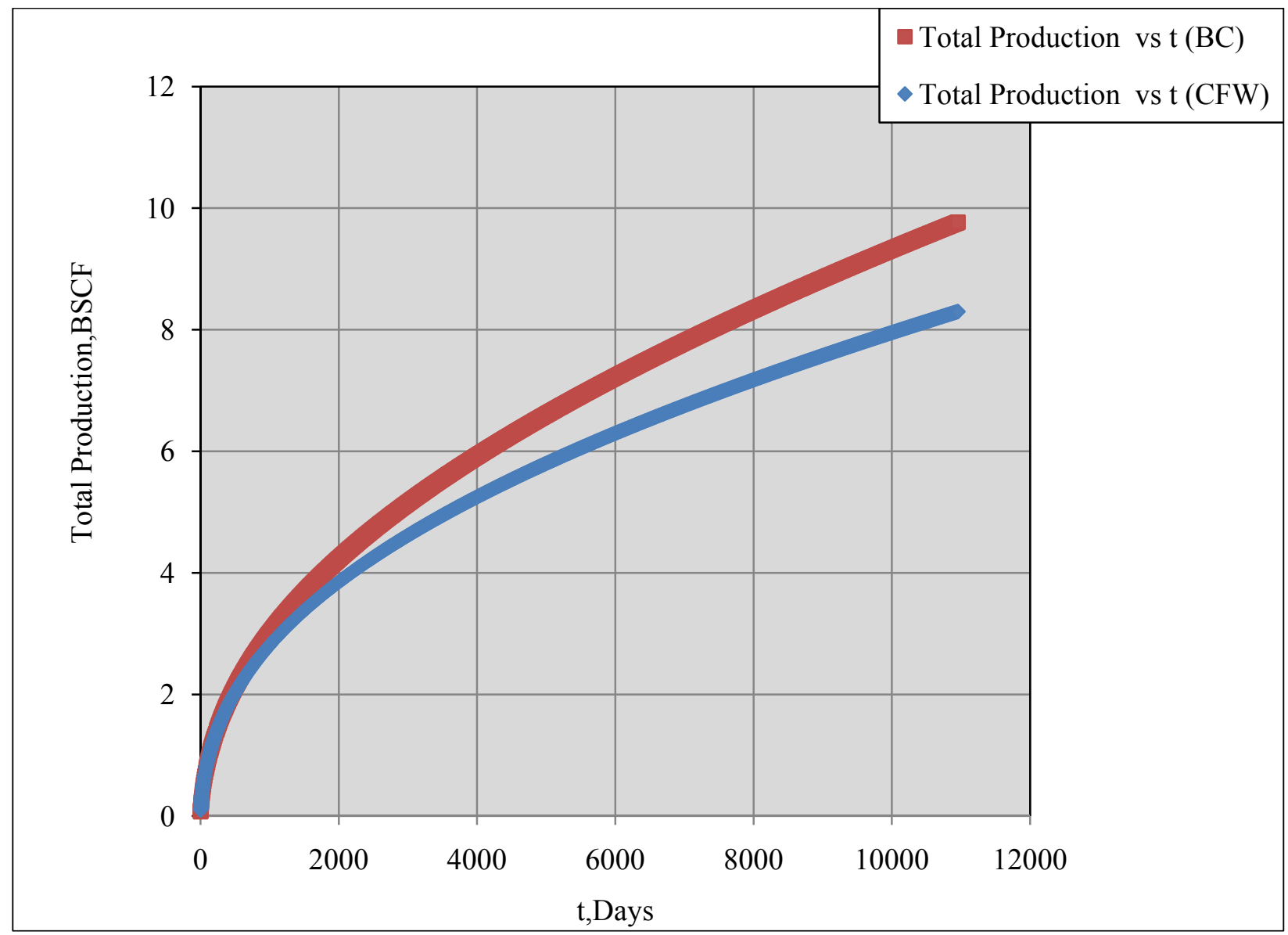

Figure IV-27 Total production versus time for the (CFW) and the (BC) with eight fracture treatments $\left(\mathrm{x}_{\mathrm{f}}=200 \mathrm{ft}\right)$. 


\subsection{Base case (BC) versus web - well (WW):}

Figure IV-28 shows pseudo pressure and its derivative for the Web- well design. The details were presented in section (3.3.7).

Figure IV-29 compares the pseudo pressures and their derivatives between the base case and the web - well case. There is an intermediate linear flow (ILF) to the induced hydraulic fractures. After this linear flow more pressure drop occurs in the (WW) pseudo pressure derivative, due to the interference between the laterals.

Productivity indices (PI) for both base case and web- well are plotted in Figure IV-30. The productivity index of Web- well is less than the base case. This reduction in the productivity index is a result of the pressure drop in the (WW) case.

Figure IV-31 shows the total production for both the (WW) and the (BC) and it confirmed that $(\mathrm{BC})$ well configuration resulted in more production than the (WW) well configuration. 


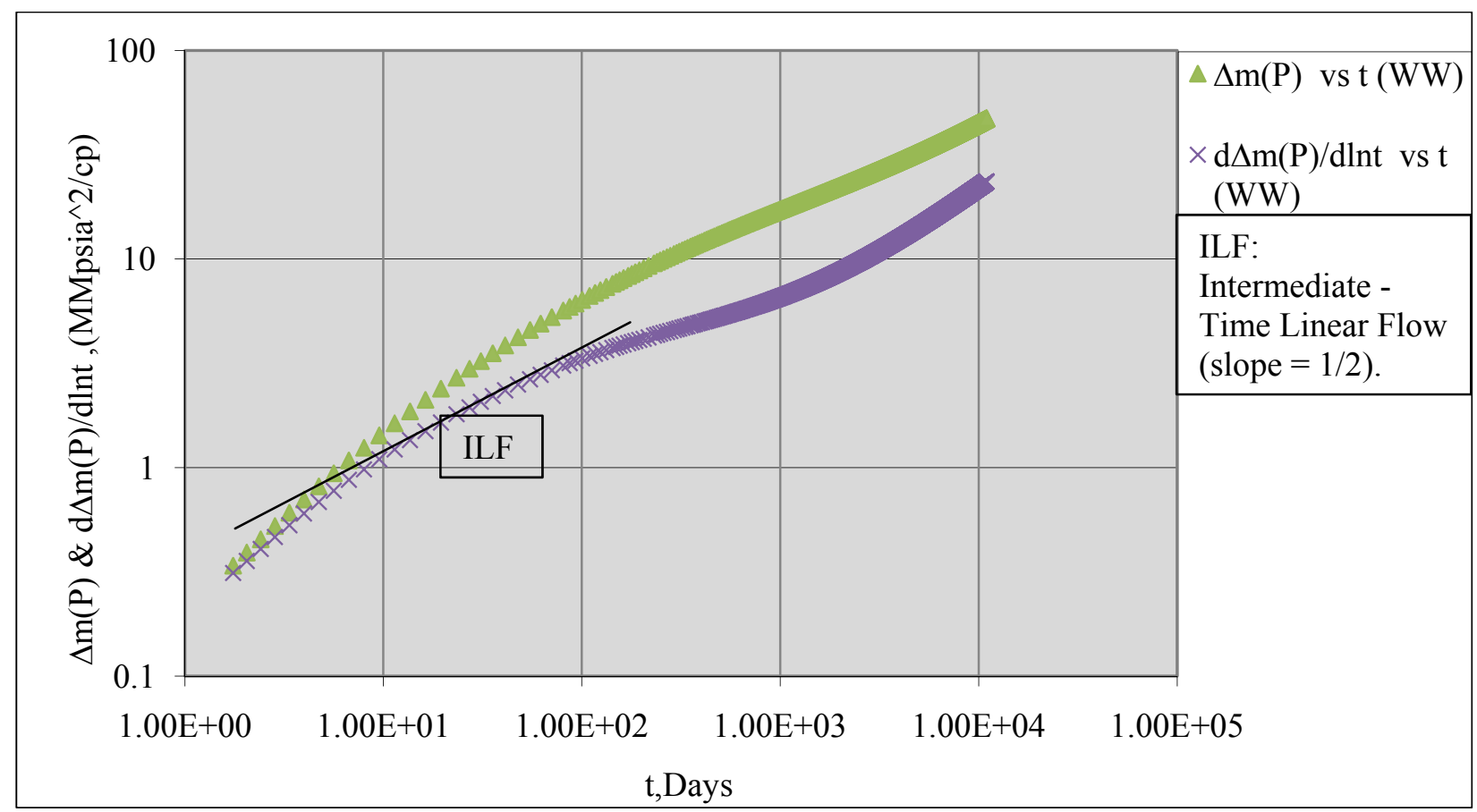

Figure IV-28 Pseudo pressure and its derivative for the (WW) case with eight fracture treatments $\left(\mathrm{x}_{\mathrm{f}}=200 \mathrm{ft}\right)$.

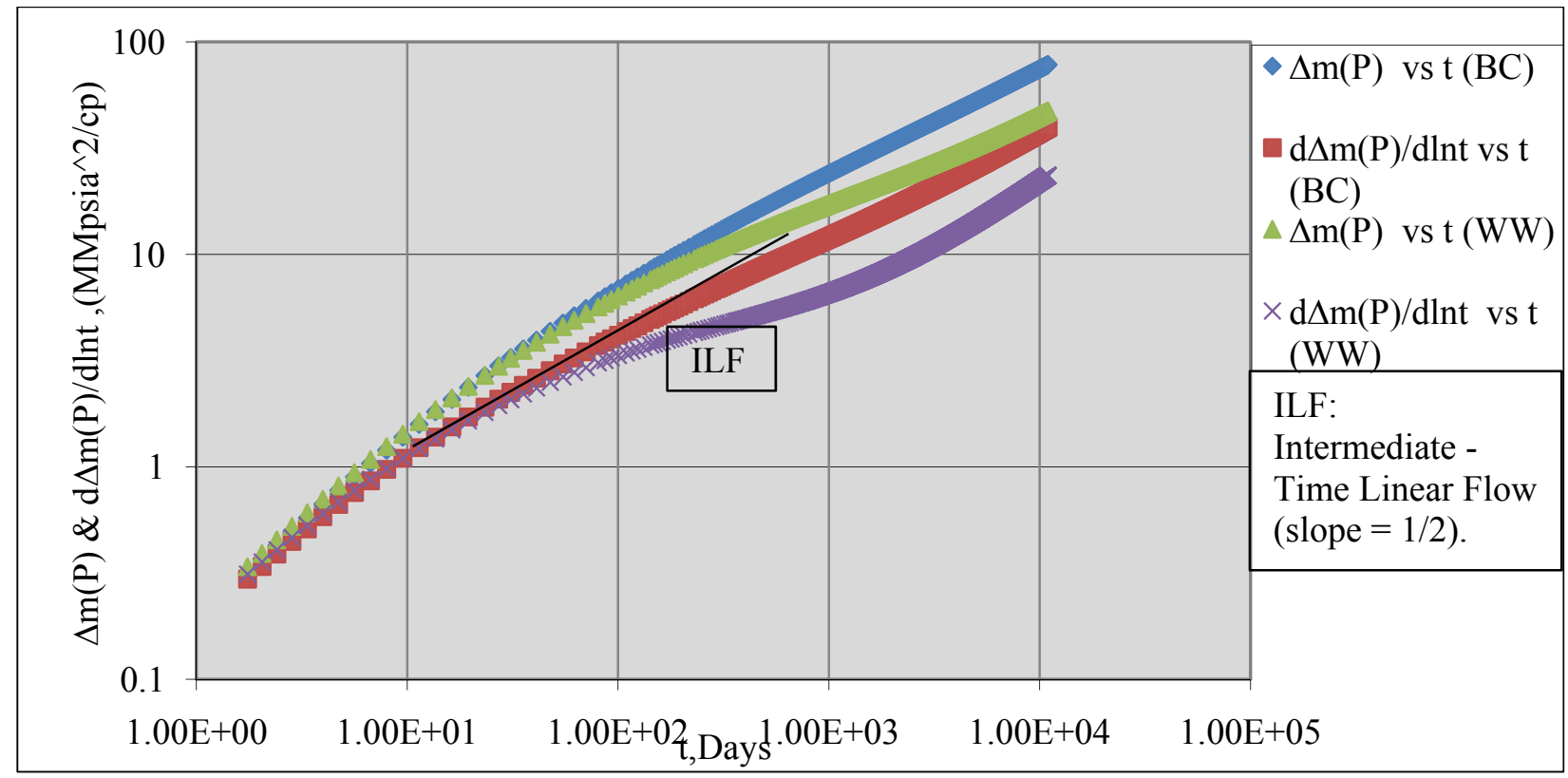

Figure IV-29 Pseudo pressure and its derivative for the (WW) and the (BC) with eight fracture treatments $\left(\mathrm{x}_{\mathrm{f}}=200 \mathrm{ft}\right)$. 


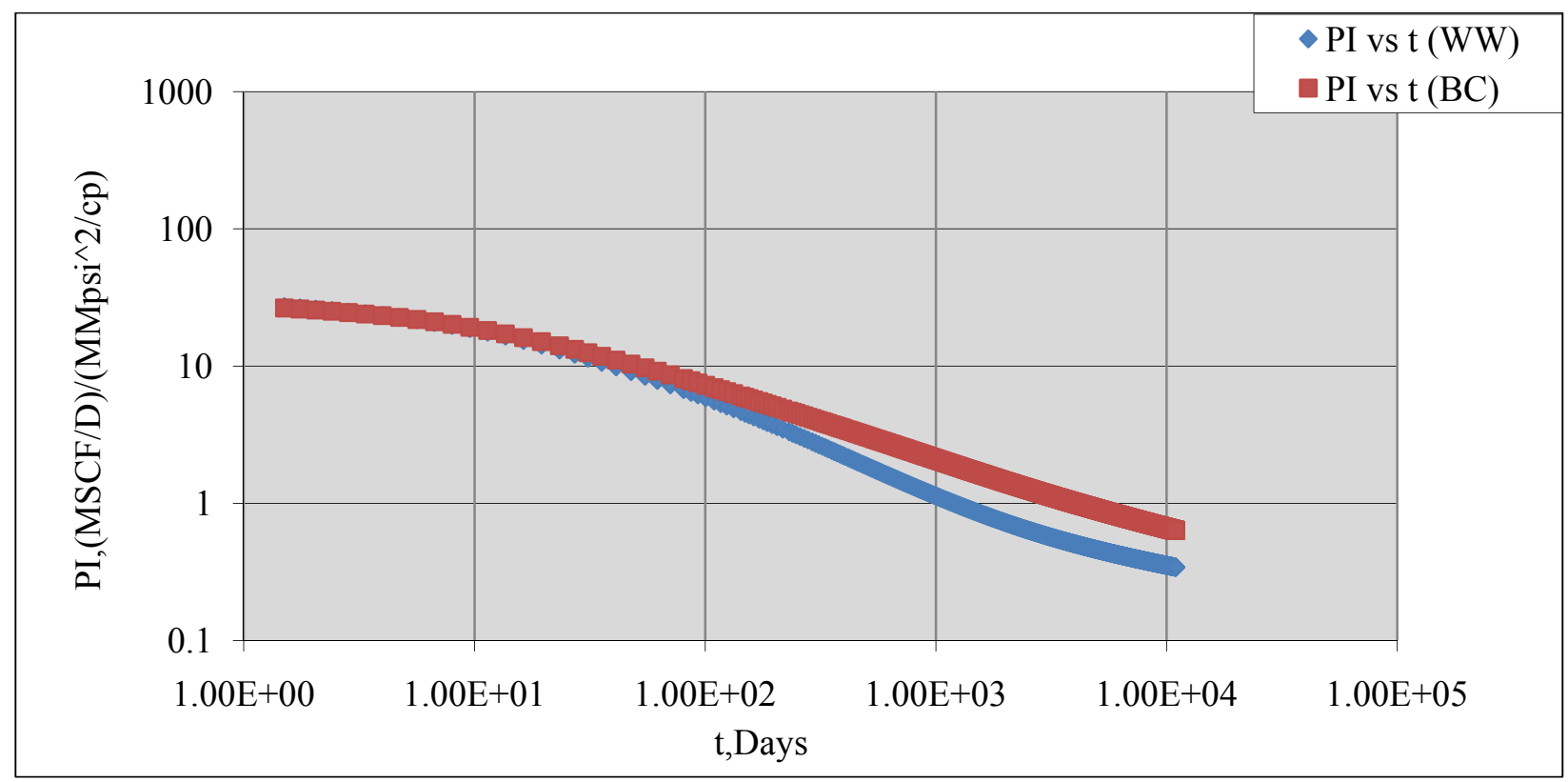

Figure IV-30 Productivity Index for the (WW) and the $(\mathrm{BC})$ with eight fracture treatments $\left(\mathrm{x}_{\mathrm{f}}=200 \mathrm{ft}\right)$.

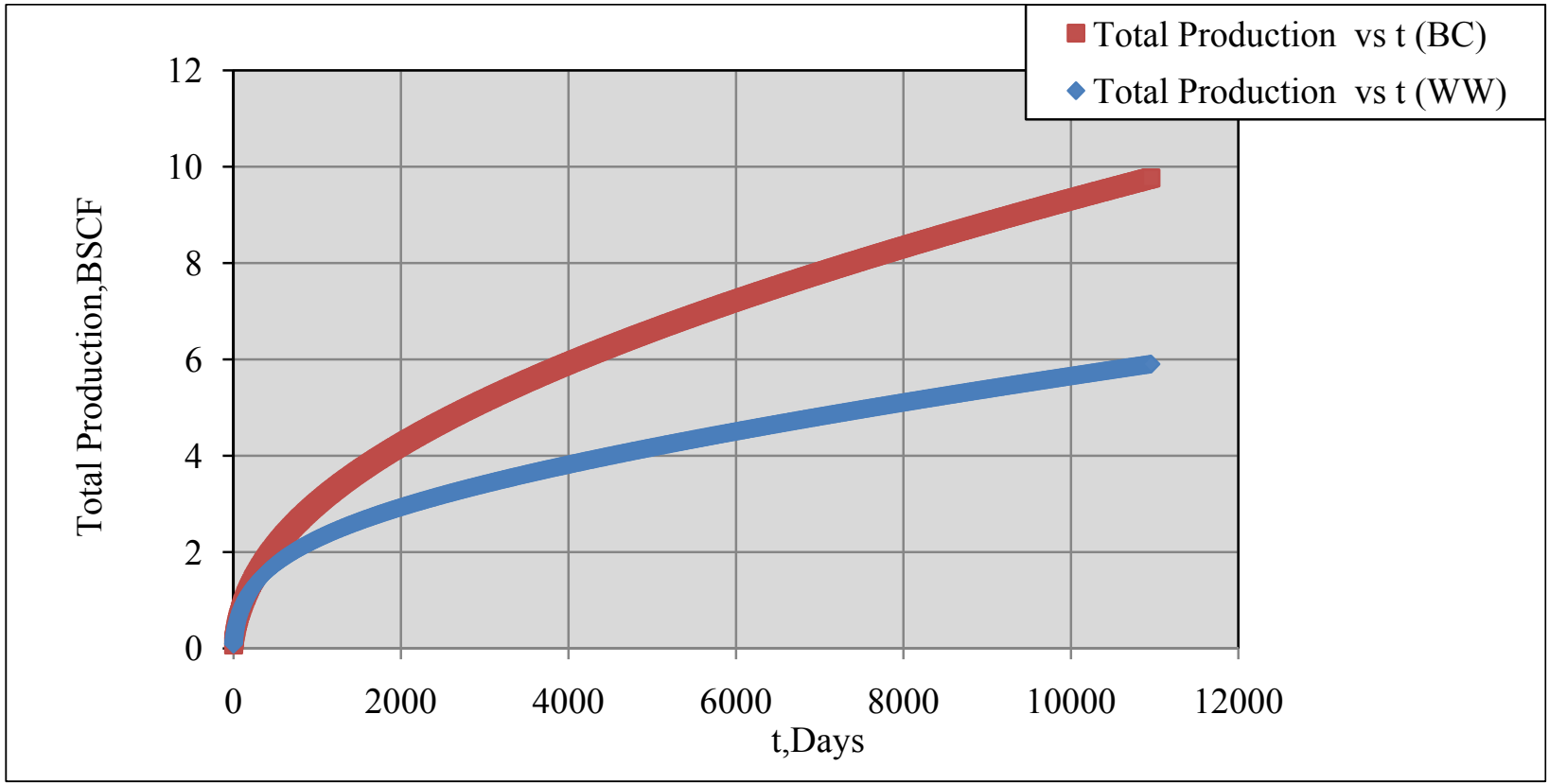

Figure IV-31 Total production versus time for the (WW) and the $(\mathrm{BC})$ with eight fracture treatments $\left(\mathrm{x}_{\mathrm{f}}=200 \mathrm{ft}\right)$. 


\subsection{Discussion:}

The effect of well configurations on the productivity index depends on the lateral spacing. When the lateral spacing decreases; more pressure drop occurs as a result of the interference between laterals and this result in a lower productivity index.

In this study, angles between laterals are used to reflect the effect of spacing between laterals. Small angle between laterals resulted in shorter lateral spacing and vice versa. Figure IV-32 compares the productivity indices for the base case (BC) with and without hydraulic fractures (HF), two parallel horizontal well (TPHW), dual - lateral well (DLW), V - well (VW), tri - lateral well (TLW), chicken foot well (CFW) and web well (WW). Figure IV-32 shows that the two parallel horizontal well has the best value for productivity index, because there is a less pressure drop through the two parallel horizontal wells. Pressure loss through the horizontal segment of $2500 \mathrm{ft}$ is less than the pressure loss through the $5000 \mathrm{ft}$ in the (BC). The (DLW) and (VW) have productivity indices slightly better than the (BC) and the (TLW) has a productivity index similar to the (BC). The (CFW) and the (WW) have productivities less than the (BC, TPHW, DLW, VW and TLW). 


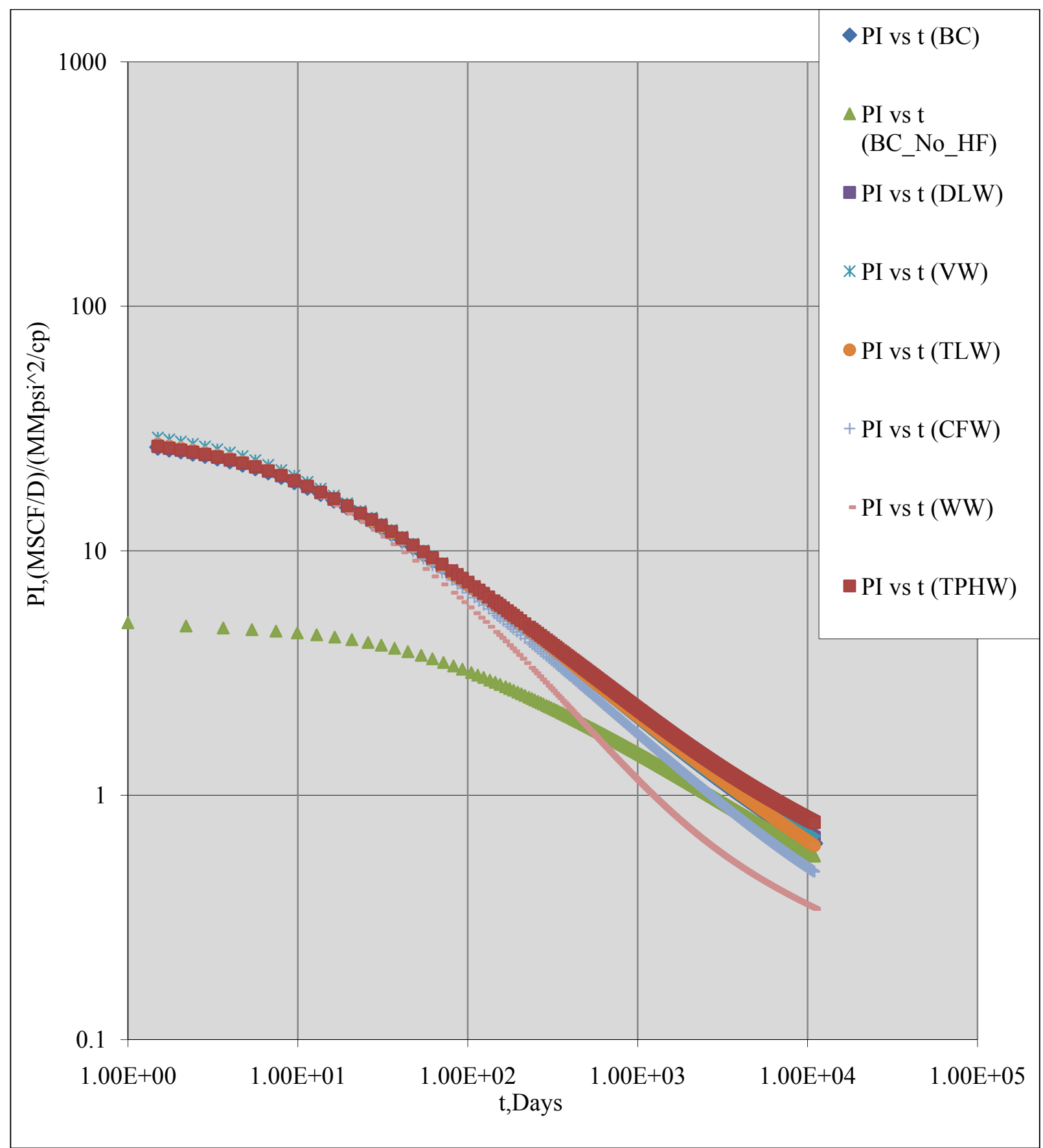

Figure IV-32 Productivity indices for the (BC) with and without HF, (TPHW), (DLW), (VW), (TLW), (CFW) and (WW). 
The second factor affecting the productivity index for both single lateral and multilateral well is the hydraulic fractures. Figure IV-32 shows the lowest value for productivity index at the early time (HF effect is clearer at the early time) for the base case without hydraulic fracture treatments. Fracture half length is critical in shale formations. Figure IV-33, shows productivity index for dual-lateral well that has sixteen stages of hydraulic fractures and two different half lengths with increase in the productivity index due to the increase in fracture half length.

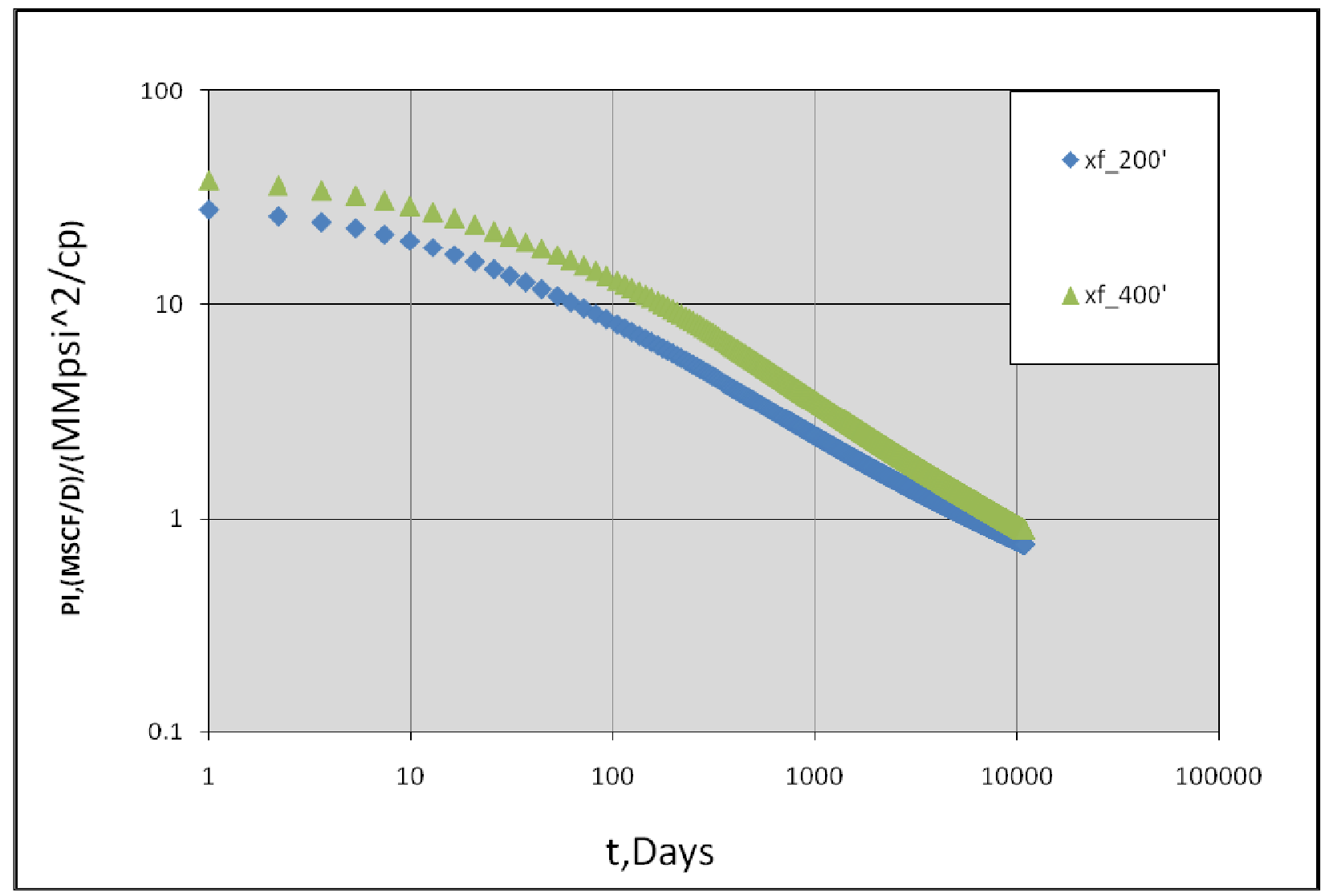

Figure IV-33 Effect of fracture half length on productivity index for a dual - lateral well with a total of 16 hydraulic fracture treatments. 
Drilling laterals that have the same length of a single horizontal well will help the shale gas producers to induce more stages of hydraulic fractures and create longer fracture half length on each stage as a result of stimulating of each lateral individually.

Figure IV-34 and Figure IV-35 show the productivity index and total production for the (DLW, VW and TLW). The (DLW) with 16 stages has a productivity better than the (DLW) with 8 stages and the total production at the end of $30^{\text {th }}$ year increase by $9.7 \%$. The (VW) total production with 16 stages increased by $8.15 \%$ and the (TLW) with 16 stages by $6.55 \%$ compared to the same well design, but with 8 stages. The (DLW) has the larger value for productivity index compared by the (VW and TLW).

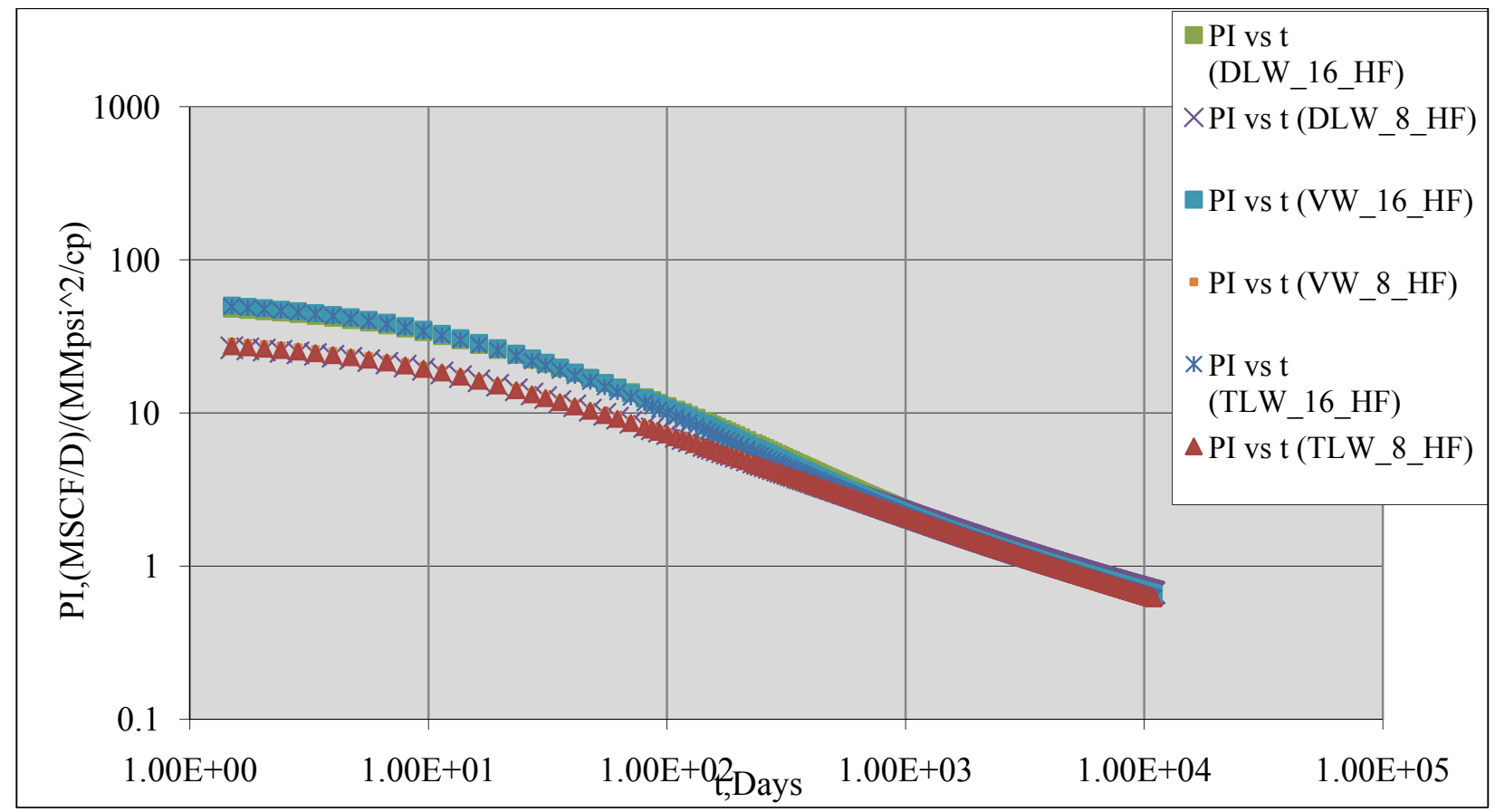

Figure IV-34 Productivity indices for the (DLW, VW and TLW) with 8 and 16 hydraulic fracture treatments $\left(\mathrm{x}_{\mathrm{f}}=200 \mathrm{ft}\right)$. 


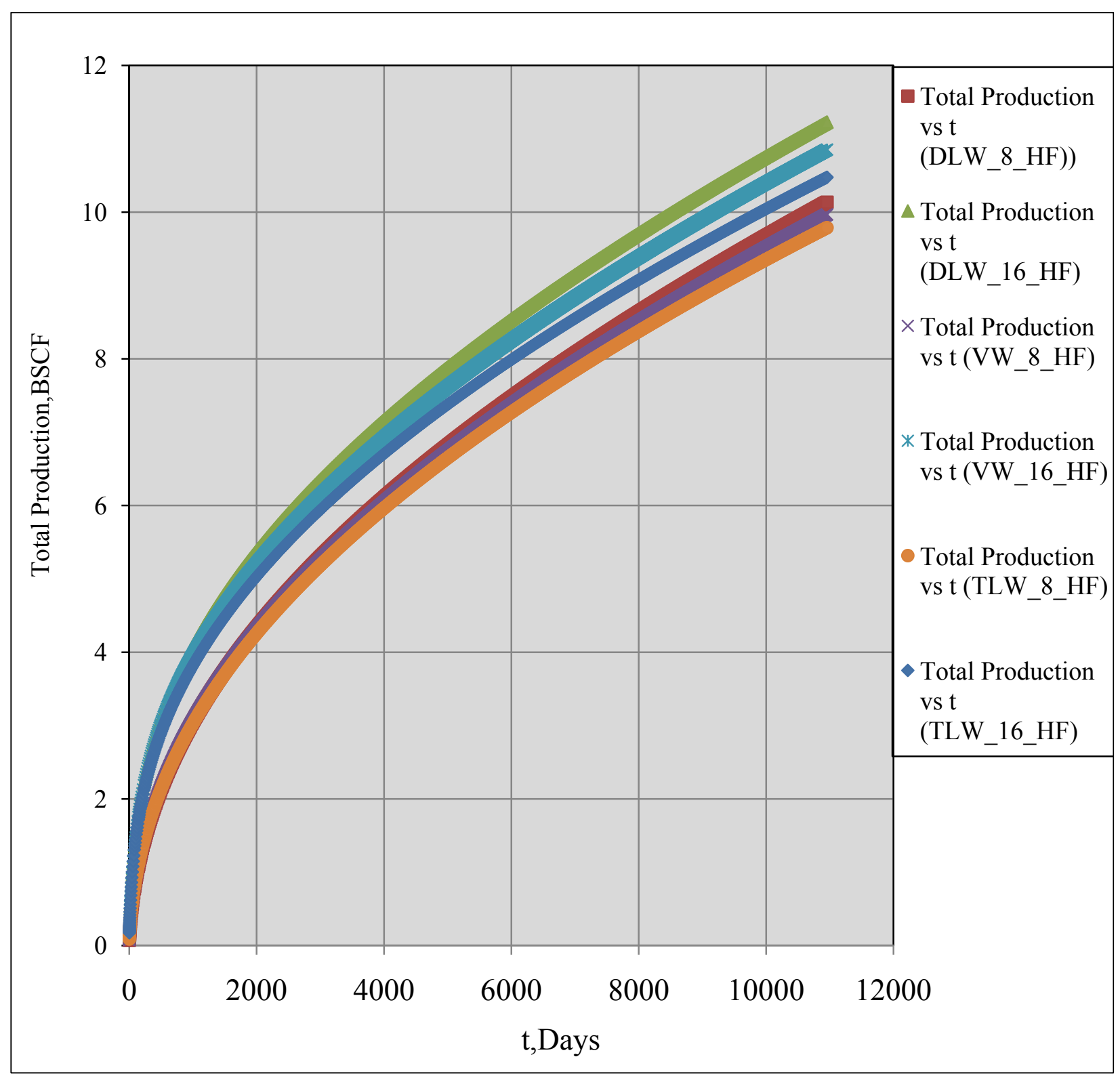

Figure IV-35 Total production versus time for the (DLW, VW and TLW) with 8 and 16 hydraulic fracture treatments $\left(\mathrm{x}_{\mathrm{f}}=200 \mathrm{ft}\right)$. 


\section{CHAPTER V}

\section{CONCLUSIONS and RECOMMENDATIONS}

\subsection{Conclusions:}

- Intermediate time linear flow in hydraulically fractured horizontal or multi-lateral wells is a result of gas flow to the induced hydraulic fractures. Early occurrence of linear flow results with better productivity index values.

- Dual - lateral well (DLW) with two opposing laterals with the $180^{\circ}$ angle between the two laterals has a better productivity index than the single horizontal well (BC), $\mathrm{V}$ - well (VW) with the $120^{\circ}$ angle between the two laterals, tri - lateral well (TLW) with the $120^{\circ}$ angle between the three laterals, Chicken foot - well (CFW) with the $60^{\circ}$ angle between the three laterals and the Web - well (WW) with the $60^{\circ}$ angle between the six laterals. All these well configurations have the same laterals length of $5000 \mathrm{ft}$.

- Spacing between the laterals has the major effect on the value of productivity index. Closer lateral spacing results with lower productivity index due to the interference between laterals.

- Hydraulic fracture half length is a key factor in the shale gas production regardless of the well configuration. 
- Using multilateral well designs give the ability to induce more stages of hydraulic fractures than the case with single horizontal well.

\subsection{Recommendations:}

- The effect of hydraulic fracture half length on the determination of the optimum lateral spacing needs future investigation.

- Additional well configurations should be considered for future study and determine their effect on the productivity index.

- Spacing between stages and its effect on the productivity index of multilateral well need to be studied.

- Additional work needs to be done on the shale gas flow behavior through the formation. 


\subsection{References:}

Araya, A and Ozkan, E.: “ An Account for Decline Type Curve Analysis of Vertical, Fractured, and Horizontal Well Production Data" paper SPE 77690, SPE Annual Technical Conference and Exhibition, San Antonio, Texas, 29 September - 2 October 2002.

Barenblatt, G.E., Zheltov, I.P. and Kochina, I.N.: "Basic Concepts in the Theory of Homogeneous Liquids in Fissured Rocks" J. Appl. Math. Mech, 24, 1286 - 1303, 1960.

Bowker, Kent A.: "Barnett Shale gas production, Fort Worth Basin: Issues and discussion” AAPG Bulletin, v.91, No.4, pp.523 - 533, April 2007.

DeSwaan, A.: “Analytical Solutions for Determining Naturally Fractured Reservoir Properties by Well Testing” SPEJ 17 - 22, Trans AIME, 261, June 1976.

Eclipse, version 2007.1, Schlumberger. Houston, TX.

Economides, Michael J., Retnanto, A., and Frick, T.P.: "Optimal Configurations of Multiple - Lateral Horizontal Wells” paper SPE 35712, Western Regional Meeting, Anchorage, Alaska, 22 - 24 May 1996. 
Gale, Julia F.W., Reed, Robert M., and Holder, Jon.: "Natural fractures in the Barnett Shale and their importance for hydraulic fracture treatments," AAPG Bulletin, v.91, No.4, pp.603 - 622, April 2007.

Gringarten, Alain.C., Ramey,JR ., Henry J.: “ The use of Source and Green's Functions in Solving Unsteady - Flow Problems in Reservoirs" paper SPE 3818, 1973.

Hill, A.D., Zhu, Ding. and Economides, Michael J.: Multilateral Wells, SPE Richardson,TX, (2008)

Kazemi, H., Merrill, L.S., Porterfield, K.L., and Zeman, P.R.: "Numerical Simulation of Water - Oil Flow in Naturally Fractured Reservoirs" SPEJ 16(6):317 - 326; Trans., AIME, 261.SPE - 5719 - PA, 1976.

Kazemi, H.: "Pressure Transient Analysis of Naturally Fractured Reservoir with Uniform Fracture Distribution”, SPEJ, 451-62 Trans., AIME 246, Dec 1969.

Lewis, Adam M., and Hughes, Richard G.: "Production Data Analysis of Shale Gas Reservoirs" paper SPE 116688, Annual Technical Conference and Exhibition, Denver, Colorado, 21 - 24 September 2008.

Maricic, Nikola. Shahab D.Mohaghegh., and Emre, Artun.: "A Parametric Study on the Benefits of Drilling Horizontal and Multilateral well in Coal Bed Methane 
Reservoirs" paper SPE 96018, Annual Technical Conference and Exhibition, Dallas, Texas, 9-12 October 2005.

Matthews, H Lee., Schein, Gary., and Malone, Mark.: "Stimulation of Gas Shale: They're All the Same - Right?", paper SPE 106070, SPE Hydraulic Fracturing Technology Conference, College Station, Texas, U.S.A.29-31 January 2007.

Matthews, H.Lee: "Overview of Shale Gas Stimulation Techniques" Oral presentation, AAPG Annual Convention, San Antonio, Texas, April 20 - 23, 2008.

Medeiros, F., Ozkan, E., and Kazemi, H. :"Productivity and Drainage Area of Fractured Horizontal Wells in Tight Gas Reservoirs” paper SPE 108110 ,SPE Rocky Mountain Oil and Gas Technology Symposium, Denver, Colorado, 16 - 18 April 2008.

Medeiros, F. Jr., Ozkan, E., and Kazemi, H.: “A Semianalytical, Pressure - Transient Model for Horizontal and Multilateral Wells in Composite, Layered, and Compartmentalized Reservoirs.”, paper SPE 102834, SPE Annual Technical Conference and Exhibition, San Antonio, Texas, 24 - 27 September 2006.

Montgomery, Scott L., Jarvie, Daniel M., Bowker, Kent A., and Pollastro, Richard M.: "Mississippian Barnett Shale, Fort Worth basin, north - central Texas: Gas shale play with multi - trillion cubic foot potential," AAPG Bulletin, v.89, No.2, pp. $155-175$, February 2005. 
Mutalik, P.N., and Gibson, Bob.: "Case History of Sequential and Simultaneous Fracturing of Barnett Shale in Parker County" paper SPE 116124, Annual Technical Conference and Exhibition, Denver, Colorado, 21 - 24 September 2008.

Ozkan, E., Brown, M., Raghavan, R., and Kazemi, H.: "Comparison of Fractured Horizontal - Well Performance in Conventional and Unconventional Reservoirs" paper SPE 121290 ,Western Regional Meeting ,San Jose, California, USA, 24 - 26 March 2009.

Ozkan, E., and Raghavan, R.: "New Solutions for Well - Test - Analysis Problem: Part 1 - Analytical Considerations", SPEREE 6 (3): 359 - 368, paper SPE - 18615 PA, 1991 a.

Ozkan, E., and Raghavan, R.:"New Solutions for Well - Test - Analysis Problem: Part 2 - Computational Consideration and Applications". SPEREE 6 (3): 369 - 378, paper SPE - $18616-P A, 1991$ b.

Powell, A. Bustos, O. Kordziel, W. Olsen, T. Sobernheim, D and Vizurraga, T.: "Fiber - Laden Fracturing Fluid Improves Production in the Bakken Shale Multilateral Play” paper SPE 107979, SPE Rocky Mountain Oil and Gas Technology Symposium, Denver, Colorado, 16 - 18 April 2007.

Warren, J.E., and Root, P.J.: "The Behavior of Naturally Fractured Reservoirs" SPE Journal, pp.445 - 455, Sep, 1963. 
Waters, G. "Completion of Hydrocarbon Bearing Shale Reservoirs" short course notes, West Virginia University, Morgantown, WV, 2009.

Wei, Y., and Economides, Michael J.: "Transverse Hydraulic Fractures from a Horizontal Well”, paper SPE 94671, Annual Technical Conference and Exhibition, Dallas, TX, 9 - 12, October 2005.

Well Test Interpretation, Schlumberger 2002. Houston, TX.

Yildiz, T "Multilateral Horizontal Well Productivity", paper SPE 94223, SPE Europe/EAGE Annual Conference, Madrid, Spain, 13-16 June 2005.

John

$\mathrm{H}$.

Hagen 